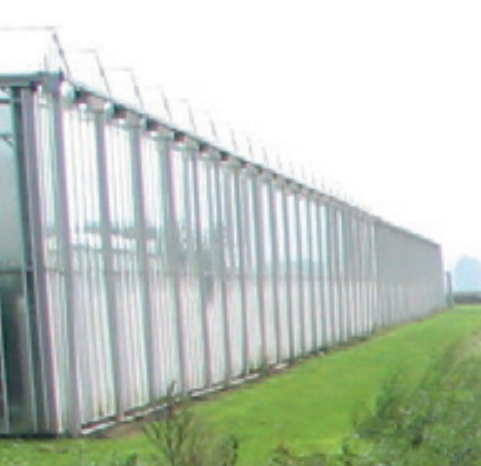





\section{Herkomst Nutriënten in het landelijk gebied van Schieland}

Peter Schipper ${ }^{1}$, Luuk van Gerven ${ }^{1}$, Erwin van Boekel ${ }^{1}$, Leo Renaud ${ }^{1}$ en Gerard Ros ${ }^{2}$

1 Wageningen Environmental Research

2 Nutriënten Management Instituut bv

Dit onderzoek is uitgevoerd door Wageningen Environmental Research in opdracht van en gefinancierd door het Hoogheemraadschap van Schieland en de Krimpenerwaard.

Wageningen Environmental Research

Wageningen, november 2019

Gereviewd door:

Piet Groenendijk, Senior onderzoeker

Akkoord voor publicatie:

Gert Jan Reinds, Teamleider Duurzaam Bodemgebruik

Rapport 2969

ISSN 1566-7197 
P.N.M. Schipper, L.P.A. van Gerven, E.M.P.M. van Boekel, L.V. Renaud, en G.H Ros, 2019. Herkomst Nutriënten in het landelijk gebied van Schieland. Wageningen, Wageningen Environmental Research, Rapport 2969. 72 blz.; 20 fig.; 20 tab.; 45 ref.

De Europese Kaderrichtlijn Water (KRW) schrijft voor dat het oppervlaktewater in 2027 voldoende schoon en ecologisch gezond is. In veel Nederlandse wateren is de nutriëntenbelasting (nog) te hoog om de doelen voor de KRW te halen. Het Hoogheemraadschap van Schieland en de Krimpenerwaard (HHSK) wil ter voorbereiding van besluiten over verbetering van de waterkwaliteit beter inzicht krijgen in de herkomst van de nutriënten in hun wateren.

In dit onderzoek is de nutriëntenbelasting van de oppervlaktewateren (en herkomst daarvan) gekwantificeerd voor de periode 2000-2013 voor negen polders in het landelijke gebied van Schieland. Ook zijn effecten van autonoom mestbeleid en enkele landbouwmaatregelen indicatief berekend en zijn de fosfaat- en stikstoftoestand van de toplaag van de landbouwgronden ruimtelijk in kaart gebracht.

De nutriëntenbelasting (en herkomst daarvan) in de beschouwde polders verschilt sterk door de grote verschillen in landgebruik, bodemtype en hydrologie. De totale nutriëntenbelasting per hectare is het grootst in polders met veel glastuinbouw, gevolgd door polders met veel akkerbouw. Af- en uitspoeling vanuit landbouwgronden leveren de grootste bijdrage aan de stikstofbelasting (gemiddeld 44\%). Dit komt vooral door actuele mestgiften. De rest van de stikstofbelasting komt vooral door diffuse lozingen vanuit glastuinbouw en diffuse bronnen in stedelijk gebied. Af- en uitspoeling leveren ook voor fosfor de grootste bijdrage (gemiddeld 52\%). Deze af- en uitspoeling worden niet zozeer door actuele mestgiften bepaald, maar meer door nalevering, historische mestgiften en kwel. De rest van de fosforbelasting komt - net als stikstof - vooral door glastuinbouw en diffuse bronnen in stedelijk gebied. De berekeningen geven aan dat met autonoom mestbeleid en de beschouwde additionele landbouwmaatregelen de nutriëntenbelasting weinig zal afnemen. Wel levert volledige aansluiting van de glastuinbouw een aanzienlijke verlaging van de belasting in de polders met veel glastuinbouw. Dit is al enkele jaren in gang gezet. Vooral in Bleiswijk zal de belasting hierdoor naar verwachting verder afnemen.

Trefwoorden: Kaderrichtlijn Water, oppervlaktewater kwaliteit, nutriënten belasting, stikstof, fosfor, herkomst, uitspoeling, afspoeling, bemesting, glastuinbouw, bodemverbetering, kringloopwijzer, fosfaattoestand, stikstof leverend vermogen

Dit rapport is gratis te downloaden van https://doi.org/10.18174/507469 of op www.wur.nl/environmental-research (ga naar 'Wageningen Environmental Research' in de grijze balk onderaan). Wageningen Environmental Research verstrekt geen gedrukte exemplaren van rapporten.

2019 Wageningen Environmental Research (instituut binnen de rechtspersoon Stichting Wageningen Research), Postbus 47, 6700 AA Wageningen, T 03174807 00, www.wur.nl/environmental-research. Wageningen Environmental Research is onderdeel van Wageningen University \& Research.

- Overname, verveelvoudiging of openbaarmaking van deze uitgave is toegestaan mits met duidelijke bronvermelding.

- Overname, verveelvoudiging of openbaarmaking is niet toegestaan voor commerciële doeleinden en/of geldelijk gewin.

- Overname, verveelvoudiging of openbaarmaking is niet toegestaan voor die gedeelten van deze uitgave waarvan duidelijk is dat de auteursrechten liggen bij derden en/of zijn voorbehouden.

Wageningen Environmental Research aanvaardt geen aansprakelijkheid voor eventuele schade voortvloeiend uit het gebruik van de resultaten van dit onderzoek of de toepassing van de adviezen.

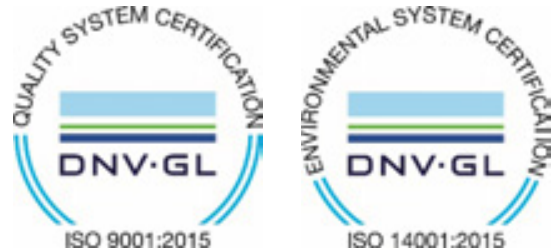

ISO 9001:2015
Wageningen Environmental Research werkt sinds 2003 met een ISO 9001 gecertificeerd kwaliteitsmanagementsysteem. In 2006 heeft Wageningen Environmental Research een milieuzorgsysteem geïmplementeerd, gecertificeerd volgens de norm ISO 14001.

Wageningen Environmental Research geeft via ISO 26000 invulling aan haar maatschappelijke verantwoordelijkheid. 


\section{Inhoud}

Verantwoording $\quad 5$

$\begin{array}{ll}\text { Samenvatting } & 7\end{array}$

$\begin{array}{lll}1 & \text { Inleiding } & 9\end{array}$

$1.1 \quad$ Achtergrond en probleemstelling $\quad 9$

1.2 Projectdoelstelling en projectresultaat 9

$\begin{array}{lll}1.3 & \text { Leeswijzer } & 9\end{array}$

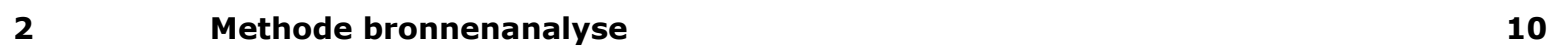

$\begin{array}{lll}2.1 & \text { Aanpak op hoofdlijnen } & 10\end{array}$

2.2 Beschrijving studiegebied $\quad 12$

$\begin{array}{lll}2.3 & \text { Bepalen af- en uitspoeling van nutriënten } & 18\end{array}$

$\begin{array}{lll}2.4 & \text { Opstellen stofbalansen en toetsing } & 19\end{array}$

$\begin{array}{lll}2.5 & \text { Herkomst nutriënten } & 27\end{array}$

$\begin{array}{lll}2.6 & \text { Maatregelen } & 28\end{array}$

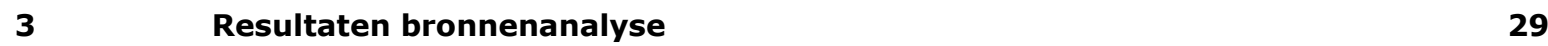

$\begin{array}{lll}3.1 & \text { Nutriëntenbelasting per polder } & 29\end{array}$

$\begin{array}{lll}3.2 & \text { Af- en uitspoeling van nutriënten } & 32\end{array}$

3.3 Herkomst nutriënten 33

$\begin{array}{lll}3.4 & \text { Reflectie op de af- en uitspoeling } & 36\end{array}$

$\begin{array}{llr}4 & \text { Maatregelen } & 37\end{array}$

$\begin{array}{lll}4.1 & \text { Algemene beschouwing over maatregelen } & 37\end{array}$

$\begin{array}{lll}4.2 & \text { Huidige mestbeleid } & 38\end{array}$

4.3 Glastuinbouw aansluiten op riool 39

$\begin{array}{lll}4.4 & \text { Onderwaterdrainage } & 39\end{array}$

$\begin{array}{lll}4.5 & \text { Bodemverbetering } & 40\end{array}$

$\begin{array}{lll}4.6 & \text { Precisiebemesting } & 41\end{array}$

$\begin{array}{lll}4.7 & \text { Kringloopwijzer-plus } & 42\end{array}$

$\begin{array}{lll}4.8 & \text { Effecten van maatregelen } & 43\end{array}$

$\begin{array}{lll}4.9 & \text { Maatwerk op perceelniveau } & 46\end{array}$

$5 \quad$ Conclusies en aanbevelingen $\quad 47$

$\begin{array}{lll}5.1 & \text { Conclusies } & 47\end{array}$

5.2 Aanbevelingen $\quad 49$

$\begin{array}{ll}\text { Literatuur } & \mathbf{5 0}\end{array}$

$\begin{array}{lll}\text { Bijlage } 1 \text { Herschikkingsprocedure } & 53\end{array}$

$\begin{array}{lll}\text { Bijlage } 2 & \text { Bronnen in de EmissieRegistratie } & \mathbf{6 0}\end{array}$

Bijlage 3 Betrouwbaarheid bronnen in de EmissieRegistratie $\quad 61$

$\begin{array}{lll}\text { Bijlage } 4 & \text { Retentie } & 62\end{array}$

$\begin{array}{lll}\text { Bijlage } 5 & \text { Resultaten herschikking } & 68\end{array}$

$\begin{array}{lll}\text { Bijlage } 6 & \text { Af- en uitspoeling per jaar } & 69\end{array}$

$\begin{array}{lll}\text { Bijlage } 7 & \text { Nutriëntenbelasting per jaar } & 70\end{array}$ 



\section{Verantwoording}

Rapport: 2969

Projectnummer: 5200044723

Wageningen Environmental Research (WENR) hecht grote waarde aan de kwaliteit van onze eindproducten. Een review van de rapporten op wetenschappelijke kwaliteit door een referent maakt standaard onderdeel uit van ons kwaliteitsbeleid.

Akkoord Referent die het heeft beoordeeld,

functie: $\quad$ Senior onderzoeker

naam: $\quad$ Piet Groenendijk

datum: 1 november 2019

Akkoord teamleider voor de inhoud,

naam: Gert Jan Reinds

datum: 1 november 2019 


\section{Samenvatting}

In de Stroomgebiedsbeheerplannen voor de $3^{\text {e }}$ periode (2022-2027) moet Nederland definitieve keuzes maken over de doelen van de waterlichamen en in te zetten maatregelen. Ter voorbereiding hierop wil Hoogheemraadschap Schieland en de Krimpenerwaard (HHSK) graag weten hoe groot de nutriëntenbelasting daadwerkelijk is en welke antropogene en overige te onderscheiden bronnen hieraan bijdragen. Voor een deel van het beheergebied (Krimpenerwaard) is dit eerder onderzocht (Schipper, 2016), maar voor het andere deel (Schieland) is dit nog onbekend. Daarom heeft HHSK voor een negental polders de volgende onderzoeksvragen geformuleerd:

a. Wat is de omvang van de huidige nutriëntenbelasting op het polderwater in Schieland?

b. Wat zijn de bronnen van de herkomst van de huidige nutriëntenbelasting en welk deel van de belasting kan, gelet op de herkomst, beleidsmatig beschouwd worden als achtergrondbelasting?

c. In hoeverre kan de nutriëntenbelasting worden teruggedrongen door het nemen van landbouwmaatregelen?

In dit onderzoek is met methode $\mathrm{ECHO}$ de nutriëntenbelasting en het aandeel van de veroorzakende bronnen voor de periode 2000-2013 gekwantificeerd voor een negental polders in het landelijke gebied van Schieland: Binnenwegse Polder, Polder De Wilde Veenen, Tweemanspolder, Polder Bleiswijk, Eendragtspolder, Zuidplaspolder-Noord, Zuidplaspolder-Zuid, Oostpolder en Polder EGB. In deze door de WUR ontwikkelde methode worden per afwateringsgebied of poldergebied met regiospecifieke perceelskenmerken rekeneenheden van het landelijke model STONE geselecteerd om de afen uitspoeling uit landbouwgronden en natuurgronden te berekenen en daarmee onderscheid te maken tussen de uitspoeling die voortkomt door actuele bemesting, historische mestgiften, atmosferische depositie, kwel en lokaal geïnfiltreerd oppervlaktewater. De overige nutriëntenbronnen worden in ECHO toegevoegd vanuit EmissieRegistratie en/of meer regiospecifieke informatie van het waterschap, waaronder effluent van rioolwaterzuiveringen en hoeveelheden en kwaliteit van het inlaatwater. In ECHO worden per gebied de bronnen van stikstof en fosfor gesommeerd en met deze belasting berekend hoeveel retentie van stikstof en fosfor in het oppervlaktewater optreedt.

Parallel hieraan zijn door het NMI de huidige stikstof- en fosfaattoestand van de bouwvoor op perceelniveau in kaart gebracht door meetgegevens van Eurofins Agro op te vragen (het agrarisch laboratorium voor bodem, mest en gewas in Nederland) en deze ruimtelijk uit te werken. De gemaakte kaartbeelden betreffen bodemkenmerken die van invloed zijn op de stikstof- en fosforbeschikbaarheid in de agrarische bodem.

Vervolgens zijn effecten van het autonome mestbeleid op de af- en uitspoeling berekend alsmede de effecten van de volgende typen landbouwmaatregelen: onderwaterdrainage, bodemverbetering, precisiebemesting, verhoging stikstofefficiency melkveebedrijven (aangeduid als 'kringloopwijzerplus') en aansluiting van glastuinbouw op het riool.

Uit het onderzoek blijkt dat de polders in Schieland grote verschillen vertonen qua totale nutriëntenbelasting (per hectare) naar het oppervlaktewater, hetgeen te maken heeft met de grote verschillen in landgebruik, bodemtype en hydrologie binnen Schieland. De polders met veel glastuinbouw (Zuidplaspolder-Zuid, Zuidplaspolder-Noord en vooral Polder Bleiswijk) hebben de grootste stikstof- en fosforbelasting (per hectare). Daarna volgen de polders met veel akkerbouw (Tweemanspolder en Polder de Wilde Venen), waarvan de belasting voornamelijk bestaat uit af- en uitspoeling vanuit het landelijk gebied. De veenweidepolders (Polder EGB en de Oostpolder, beide gekenmerkt door wegzijging) en de polders met veel stedelijk gebied (Eendragtspolder en vooral Binnenwegse polder) hebben de laagste nutriëntenbelasting.

Een deel van de belasting is afkomstig van bronnen die beleidsmatig aangewezen kunnen worden als natuurlijk of seminatuurlijk. Deze bronnen worden ook wel gekarakteriseerd als moeilijk of nietbeïnvloedbare bronnen. Het totale aandeel hiervan wordt beleidsmatig aangeduid als theoretische 
achtergrondbelasting. Bij de berekening van deze achtergrondbelasting is ervan uitgegaan dat de volgende bronnen als natuurlijk of seminatuurlijk worden beschouwd: uitspoeling vanuit natuurgronden, uitspoeling vanuit landbouwgronden die veroorzaakt wordt door kwel, nalevering, depositie en eerder geïnfiltreerd oppervlaktewater, atmosferische depositie op open water en kwel die direct uittreedt naar oppervlaktewater. Voor stikstof varieert deze achtergrondbelasting tussen de 30 en $70 \%$ (gemiddeld $48 \%$ ). De achtergrondbelasting van stikstof is relatief laag in de polders met veel glastuinbouw (Bleiswijk, Zuidplas-Noord en -Zuid) en de polders met veel akkerbouw (Wilde Veenen en Tweemans). Voor fosfor is de achtergrondbelasting een stuk hoger, namelijk gemiddeld $67 \%$ (variërend tussen 35 en 85\%). Dit komt vooral door een grotere bijdrage in de uitspoeling door nalevering en kwel. In de akkerbouwpolders en de veenweidepolders met infiltratie (EGB en Oostpolder) is een belangrijk deel afkomstig van 'historische bemesting'.

Met de aldus naar herkomst uitgesplitste belasting kunnen theoretische achtergrondconcentraties worden afgeleid en keuzes onderbouwd voor de inzet van maatregelen en het eventueel technisch bijstellen van waterkwaliteitsdoelen.

De stikstof en fosfaat toestand van de toplaag (10 cm bij grasland, $25 \mathrm{~cm}$ bij bouwland) toont grote ruimtelijke verschillen. Het is onduidelijk of informatie over de ruimtelijke verschillen leidt tot wijzigingen in het beeld van de berekende af- en uitspoeling. Berekeningen in deze en andere veenweidegebieden laten zien dat de belangrijkste P-verliezen optreden vanuit de diepere bodemlagen, vooral als sprake is van kwel. De eventuele over- of onderschatting van de uit- en afspoeling uit de toplaag zal de totale af- en uitspoeling en daarmee de berekende herkomst waarschijnlijk niet wezenlijk veranderen.

In polders met veel glastuinbouw is de verwachte reductie van de lozingen door aansluiting op het riool effectief (geweest) om de diffuse nutriëntenbelasting van het oppervlaktewater te verminderen. Dit geldt vooral voor de polder Bleiswijk, omdat daar volgens HHSK pas vanaf 2014 de glastuinbouwberdrijven zijn aangesloten op het riool en deze aansluiting volgens de berekeningen de totale stikstof- en fosforbelasting ongeveer halveert. In de polders Zuidplas-Noord en Zuidplas-Zuid was aansluiting op het riool al vanaf 2010 in gang gezet. Aanbevolen wordt om met handhaving en communicatie te volgen of er situaties zijn waar de aansluitingen op het riool niet goed zijn aangelegd en of morsingen en calamiteiten die leiden tot lozingen van het gietwater kunnen worden voorkomen.

De berekende effecten van autonoom mestbeleid en andere type landbouwmaatregelen zijn gering. De af- en uitspoeling kunnen weliswaar met enkele procenten (tot zo'n 15\%) afnemen door een betere benutting van de nutriënten met bodemverbeterende en 'Kringloopwijzer-plus'-maatregelen en waar mogelijk onderwaterdrainage, maar omdat de af- en uitspoeling van landbouwgronden geen dominant aandeel hebben in de totale nutriëntenbelasting, is het effect van deze maatregelen op de totale nutriëntenbelasting gering.

Ondanks dat de effecten gering lijken, wordt aanbevolen om maatregelen te stimuleren voor een betere benutting van nutriënten door de landbouw- en akkerbouwbedrijven, omdat dit in de regel bijdraagt aan een positiever bedrijfsresultaat én aan een betere waterkwaliteit. De gemaakte kaartbeelden van de $\mathrm{N}$ - en P-toestand van de bouwvoor biedt voor dit type maatregelen de nodige houvast. Onderwaterdrainage draagt naast verbetering van de waterkwaliteit ook bij aan het afremmen van maaivelddaling. Mestvrije bufferstroken kunnen effectief zijn om risico's van oppervlakkige afstroming te beperken. Deze hebben dan tegelijkertijd een positieve invloed op de biodiversiteit.

Om N- en P-concentraties in het oppervlaktewater substantieel te verlagen, kan het effectiever zijn om maatregelen te nemen waardoor de retentie in de watergangen toeneemt door bijvoorbeeld vergroening van slootranden (kruidenrijke natte bufferstroken, natuurlijkvriendelijke oevers, heolofytenfilters mestvrije akkerranden), hetgeen ook bijdraagt aan meer biodiversiteit, maar ook door de sloten op diepte te houden, slootmaaisel te verwijderen en vertrapping van oevers te voorkomen. Daarbij wordt aanbevolen om meer kennis op te bouwen over de huidige retentie, bijvoorbeeld door het monitoren van de kwaliteit van de waterbodems en de hoeveelheden en samenstelling van bagger en waterplanten die uit de watergangen worden verwijderd. 


\section{$1 \quad$ Inleiding}

\subsection{Achtergrond en probleemstelling}

Schoon en gezond water is een essentiële randvoorwaarde voor planten en dieren en een belangrijk onderdeel van een gezonde leefomgeving. De waterkwaliteit is de afgelopen decennia weliswaar verbeterd, maar Nederland heeft nog belangrijke opgaven. ${ }^{1}$ Voor het nieuwe beleid, de Delta-Aanpak Waterkwaliteit en Zoetwater (DAWZ) ${ }^{2}$, werken overheden, maatschappelijke organisaties en kennisinstituten samen om de waterkwaliteit te verbeteren en de doelen van de Europese Kaderrichtlijn Water (KRW) in 2027 te bereiken. Een van de zorgpunten voor het bereiken van de KRW-doelen is de hoge nutriëntenbelasting vanuit het landelijk gebied. ${ }^{3}$ Ook voor het Hoogheemraadschap van Schieland en Krimpenerwaard (HHSK) is dit een zorgpunt.

In de Stroomgebiedsbeheerplannen voor de $3^{e}$ periode (2022-2027) moet Nederland definitieve keuzes maken over de doelen van de waterlichamen en in te zetten maatregelen. Ter voorbereiding hierop wil HHSK graag weten hoe groot de nutriëntenbelasting daadwerkelijk is en wat de herkomst van de belasting is. Voor een deel van het beheergebied (Krimpenerwaard) is dit eerder onderzocht (Schipper, 2016), maar voor het andere deel (Schieland) is dit nog onbekend. Daarom heeft HHSK voor een negental polders de volgende onderzoeksvragen geformuleerd:

a. Wat is de omvang van de huidige nutriëntenbelasting op het polderwater in Schieland?

b. Wat zijn de bronnen van de herkomst van de huidige nutriëntenbelasting en welk deel van de belasting kan, gelet op de herkomst, beleidsmatig beschouwd worden als achtergrondbelasting?

c. In hoeverre kan de nutriëntenbelasting worden teruggedrongen door het nemen van landbouwmaatregelen?

\subsection{Projectdoelstelling en projectresultaat}

Het doel van de studie is het kwantificeren van de huidige nutriëntenbelasting (stikstof en fosfor) van het regionale oppervlaktewater in het landelijk gebied van Schieland en om inzicht te geven in de nutriëntenbronnen in het gebied, waaronder de af- en uitspoeling uit landbouwgronden. Een verdere opsplitsing van de af- en uitspoeling uit landbouwgronden naar herkomst is een belangrijk onderdeel hierin. Naast het in beeld brengen van de herkomst van bronnen wordt ook het effect van een aantal landbouwmaatregelen op de af- en uitspoeling van stikstof en fosfor uit landbouwpercelen in beeld gebracht. Specifiek richt deze studie zich op negen polders, waarbij de huidige toestand betrekking heeft op de periode 2000-2013. De volgende polders zijn onderzocht: Binnenwegse Polder, Polder De Wilde Veenen, Tweemanspolder, Polder Bleiswijk, Eendragtspolder, Zuidplaspolder-Noord, Zuidplaspolder-Zuid, Oostpolder en Polder EGB. De andere, meer stedelijke gebieden binnen het beheergebied van Schieland zijn in deze studie buiten beschouwing gelaten, omdat de gebruikte methodiek is ontworpen voor het landelijke gebied en minder toepasbaar is op stedelijk gebied.

\subsection{Leeswijzer}

In hoofdstuk 2 wordt ingegaan op de methode van de bronnenanalyse. Hoofdstuk 3 beschrijft de resultaten van de bronnenanalyse: de nutriëntenbelasting per polder en de herkomst van deze nutriënten. Hoofdstuk 4 beschrijft de maatregelen en hun effect op de nutriëntenbelasting. De conclusies en aanbevelingen zijn opgenomen in hoofdstuk 5.

Adviescommissie water, Advies Waterkwaliteit 9 mei 2016

2 Waterkwaliteit zoetwater en waterketen, brief van Minister Schulz aan de $2^{\mathrm{e}}$ kamer voor Wetgevingsoverleg Water 14 november 2016.

3 Gaalen, F. van (2015), Waterkwaliteit nu en in de toekomst. Eindrapportage ex-ante-evaluatie van de Nederlandse plannen voor de Kaderrichtlijn Water, Den Haag: PBL. 


\section{Methode bronnenanalyse}

\subsection{Aanpak op hoofdlijnen}

Voor het beantwoorden van de kennisvragen uit dit onderzoek is gebruikgemaakt van de ECHOsystematiek, die bestaat uit meerdere onderdelen (zie kader).

\section{ECHO-methodiek}

De ECHO-methodiek combineert model- en data-analysetechnieken die zijn ontwikkeld voor de exante-evaluatie van de KRW, de Evaluatie van de Meststoffenwet en monitoring- en modelstudies op regionaal niveau. De ECHO-methodiek bestaat uit verschillende onderdelen die, afhankelijk van de kennisvragen, uitgevoerd kunnen worden:

1. Stoffenbalansen: opstellen van stofbalansen voor waterlichamen/afvoergebieden waarin inzicht wordt gegeven in:

- af- en uitspoeling vanuit landbouw- en natuurgronden;

- in- en uitgaande nutriëntenvrachten op basis van metingen (debieten en concentraties);

- overige punt- en diffuse bronnen uit de EmissieRegistratie, aangevuld met regionale gegevens;

- retentie van nutriënten in het oppervlaktewater, inclusief waterbodem.

2. Uit- en afspoeling landelijk gebied

a. Herschikkingsprocedure: verbeteren van de af- en uitspoeling uit landbouw- en natuurgronden door de landelijke geschematiseerde SWAP-ANIMO-rekenplots van STONE met regionale informatie te herschikken;

b. SWAP-ANIMO-berekeningen (optioneel): verbeteren van de af- en uitspoeling uit landbouw-en natuurgronden door nieuwe berekeningen met SWAP-ANIMO uit te voeren met regionale informatie.

3. Plausibiliteitstool:

a. Toetsing: vergelijking van de berekende en uit metingen afgeleide $\mathrm{N}$ - en P-vrachten naar het oppervlaktewater om inzicht te krijgen in de plausibiliteit van de modeluitkomsten/meetgegevens;

b. Onzekerheidsanalyse: hiermee wordt inzicht verkregen in de betrouwbaarheid (onzekerheden) van de met $\mathrm{ECHO}$ berekende nutriëntenvrachten en meetgegevens.

4. Herkomstanalyse: ontrafelen van de bronnen van herkomst achter de af- en uitspoeling: actuele en historische bemesting, kwel, atmosferische depositie op landbouwgronden, nalevering landbouwgronden door mineralisatie en uitloging en af- en uitspoeling natuurgronden.

5. Effecten maatregelen

a. Kwantificeren van de effecten van voorgenomen beleid (Mestbeleid, Stroomgebiedbeheerplannen) op de N- en P-belasting van het oppervlaktewater;

b. Kwantificeren van de effecten van aanvullende (landbouwkundige) maatregelen op de $\mathrm{N}$ - en P-belasting van het oppervlaktewater.

In overleg met het waterschap is bekeken welke onderdelen (of subonderdelen) van de ECHOsystematiek wenselijk en noodzakelijk zijn voor het beantwoorden van de kennisvragen. Tijdens het overleg is ervoor gekozen om de onderdelen $1,2 a, 3 a$, 4 en 5 uit te voeren en de onderdelen $2 b$ en $3 b$ niet. Een gedetailleerde uitwerking van de methodiek wordt beschreven in paragraaf 2.4.

Bij het opstellen van de stoffenbalans is op een aantal punten afgeweken van bovenstaande aanpak:

- Ingaande nutriëntenvrachten: de hoeveelheid inlaatwater in de polders is niet bepaald met metingen (omdat deze ontbraken), maar is berekend. Hierbij is bepaald hoeveel inlaatwater er nodig is voor peilhandhaving. Deze inlaatbehoefte is op basis van expert judgement opgehoogd met een doorspoelbehoefte. 
- Diffuse bronnen uit de EmissieRegistratie (ER, versie 2013): voor de glastuinbouw en de atmosferische depositie op open water zijn de belastingen die volgen uit de EmissieRegistratie verder verfijnd met regionale gegevens.

- Emissies vanuit het stedelijk gebied: ER geeft voor het stedelijke gebied alleen de bijdrage van regenwaterriolen en overstorten (deze bijdrage zit in de term 'overige bronnen'). De bijdrage van stedelijk groen en bronnen als excretie door honden, eenden en bladval mist in de Emissieregistratie. Deze bronnen zijn daarom aanvullend bepaald in deze studie.

- Nutriëntenbelasting via directe kwel: directe kwel op waterlopen mist in de EmissieRegistratie, maar kan toch een significante nutriëntenbron zijn, met name in grotere en diepere waterlopen. Daarom is deze bron aanvullend bepaald in dit onderzoek.

De in dit onderzoek doorlopen stappen zijn weergegeven in tabel 2.1.

Tabel 2.1 Het in deze studie gevolgde stappenplan ter bepaling van de herkomst en stuurbaarheid van de nutriëntenbelasting in het landelijk gebied van Schieland.

\begin{tabular}{|c|c|}
\hline Stappen & Werkzaamheden \\
\hline $\begin{array}{l}\text { Stap } 1 . \text { Verzamelen gebiedsinformatie } \\
\text { over de kenmerken van het studiegebied } \\
\text { (paragraaf } 2.2 \text { ) }\end{array}$ & $\begin{array}{l}\text { Verzamelen, analyse en verwerking van de volgende gegevens: } \\
\text { - Landgebruik, bodem- en GT-kaart } \\
\text { - Analyse Debieten in- en uitlaat bemalingsgebieden } \\
\text { - N- en P-concentraties in- en uitlaatwater } \\
\text { - Kwel/wegzijging } \\
\text { - Grondwaterkwaliteit eerste watervoerende pakket (fosfaat en ammonium) } \\
\text { - Bodemkwaliteitsgegevens agrarische percelen (data Eurofins-Agro) }\end{array}$ \\
\hline $\begin{array}{l}\text { Stap 2. Regionaliseren van STONE-plots } \\
\text { ter nauwkeurigere berekening van de af- } \\
\text { en uitspoeling (Herschikkingsprocedure) } \\
\text { (paragraaf } 2.3 \text { ) }\end{array}$ & $\begin{array}{l}\text { - Gebiedsanalyse bemalingsgebieden } \\
\text { - Uitvoeren herschikkingsprocedure: koppelen STONE-plots aan } 25 \times 25 \mathrm{~m} \text {-grids } \\
\text { o.b.v. LGN7, bodem- en Gt-kaart en buisdrainage } \\
\text { - Uitwerken Eufofins data }\end{array}$ \\
\hline $\begin{array}{l}\text { Stap 4. Bronnenanalyse en } \\
\text { achtergrondbelasting (paragraaf } 2.5 \text { ) }\end{array}$ & $\begin{array}{l}\text { - Doortrekken af- en uitspoelings-berekeningen naar einde KRW-planperiode } \\
\text { (2027) conform mestbeleid 5e NAP } \\
\text { - Analyse herkomst bronnen achter af- en uitspoeling (voor situatie in 2027) } \\
\text { - Onderverdeling nutriëntenbelasting naar beïnvloedbaarheid en } \\
\text { achtergrondbelasting }\end{array}$ \\
\hline $\begin{array}{l}\text { Stap 5. Effecten mestbeleid en } \\
\text { landbouwmaatregelen op af- en } \\
\text { uitspoeling (paragraaf } 2.6 \text { ) }\end{array}$ & $\begin{array}{l}\text { - Berekening effect enkele type landbouwmaatregelen op de } \\
\text { nutriëntenbelasting }\end{array}$ \\
\hline
\end{tabular}

In aanvulling op de stappen van de ECHO-methode zijn door het NMI de N- en P-toestand van de bouwvoor op perceelniveau in kaart gebracht. De fosfaat- en stikstofbeschikbaarheid voor gewasopname en het risico op af- en uitspoeling worden mede bepaald door de concentraties en vorm waarin deze nutriënten voorkomen in de toplaag (bovenste decimeters) van de bodem. Voor het studiegebied is dit in kaart gebracht door meetgegevens van Eurofins Agro op te vragen (het agrarisch laboratorium voor bodem, mest en gewas in Nederland) en hiermee kaarten te maken voor de landbouwpercelen. De gemaakte kaartbeelden betreffen bodemkenmerken die van invloed zijn op de stikstof- en fosfaat-beschikbaarheid in de agrarische bodem, en de daaraan gerelateerde gewasopname en af- en uitspoeling van stikstof en fosfaat (Van Rotterdam, 2016; Ros, 2015):

- De hoeveelheid fosfaat $(P)$ in de bovenste decimeters van de bodem (10 cm bij grasland en $25 \mathrm{~cm}$ bij bouwland). Deze hoeveelheid is van invloed op de bemestingsruimte op landbouwbedrijven. De bepaling van de fosfaathoeveelheid verschilt voor bouwland en grasland. Voor bouwland gebruikt men het Pw-getal (fosfaatextractie met water, $\mathrm{mg}_{2} \mathrm{O}_{5} \mathrm{I}^{-1}$ ) en voor grasland het PAL-getal 
(fosfaatextractie met ammonium-lactaat, $\mathrm{mg} \mathrm{P}_{2} \mathrm{O}_{5} 100 \mathrm{~g}^{-1}$ ). Daarnaast wordt ook standaard de hoeveelheid plantbeschikbaar fosfaat gemeten via een extractie met $0,01 \mathrm{M} \mathrm{CaCl}_{2}$.

- Het gehalte organische stof (\%) en organische stikstof in de bovenste decimeters van de bodem ( $\mathrm{mg} \mathrm{N} \mathrm{kg}{ }^{-1}$ ) en de afbreekbaarheid ervan zoals dat gemeten wordt via een anaerobe incubatiemethode ( $\mathrm{N}$-mineralisatiesnelheid, $\mathrm{mg} \mathrm{N} \mathrm{kg}^{-1}$ ).

- De P-verzadiging (\%) van de bovenste decimeters van de bodem, dat wil zeggen de mate waarin een grond is 'opgeladen' met fosfaat en risico's oplevert voor P-verliezen naar het oppervlaktewater.

Om deze kaarten te maken, is gebiedsdekkende informatie benut van het landgebruik, bodemtype en vochthuishouding van de bodems, omdat deze van invloed zijn op de concentraties en vorm waarin de nutriënten voorkomen in de toplaag. De gebruikte wijze om hiervan kaarten te maken, is beschreven in een afzonderlijke rapportage (Verweij, 2018).

\subsection{Beschrijving studiegebied}

Studiegebied en onderscheiden bemalingsgebieden

De studie is uitgevoerd in een negental bemalingsgebieden in het landelijke gebied van Schieland (figuur 2.1). De afvoer van water vanuit deze polders verloopt via poldergemalen die uitslaan op de boezem (Ringvaart en Rotteboezem). De boezem voert dit water vervolgens af naar het buitenwater van de Hollandse IJssel en de Nieuwe Maas. De Oostpolder en Polder EGB zijn de enige onderzochte polders die hun water gelijk uitslaan op de Hollandse IJssel en niet eerst op de boezem. Ten tijde van een watertekort krijgen alle polders water uit de boezem. Dit gebeurt via een aantal door HHSK beheerde inlaten, maar ook via vele particuliere inlaten. De boezem krijgt zijn water uit de Nieuwe Maas en de Hollandse IJssel. Ook wordt in zeer droge perioden soms water ingelaten vanuit Delfland.

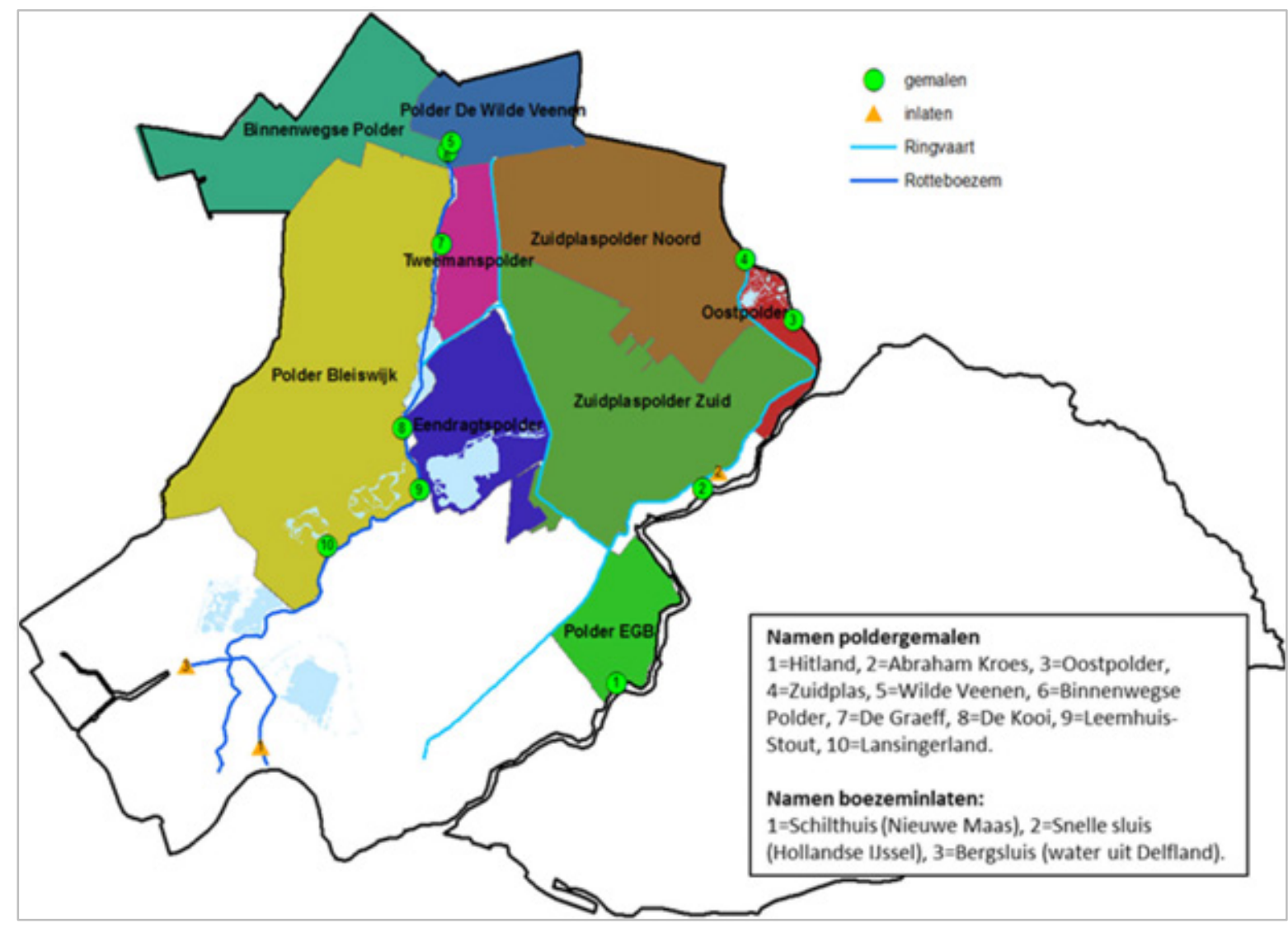

Figuur 2.1 Het beheergebied van HHSK (zwarte lijnen) en de polders waar deze studie zich op richt. Voor elke polder is het poldergemaal (groen) aangegeven dat polderwater uitslaat op de boezem. De boezem bestaat uit de Rotteboezem en de Ringvaart, die in verbinding staan met het buitenwater (Nieuwe Maas en Hollandse IJssel) via gemalen en inlaten (oranje). 
Tabel 2.2 De onderzochte polders en hun bijbehorende gemaal, met tussen haakjes het nummer dat is gebruikt in figuur 2.1 .

\begin{tabular}{ll} 
Polder & Gemalen \\
\hline Polder EGB & Hitland (1) \\
\hline Zuidplaspolder-Zuid & Abraham Kroes (2) \\
\hline Oostpolder & Oostpolder (3) \\
\hline Zuidplaspolder-Noord & Zuidplas (4) \\
\hline Polder de Wilde Veenen & Wilde Veenen (5) \\
\hline Binnenwegse Polder & Binnenwegse Polder (6) \\
\hline Tweemanspolder & De Graeff (7) \\
\hline Polder Bleiswijk & De Kooi (8) en Lansingerland (10) \\
\hline Eendragtspolder & Leemhuis-Stout (9) \\
\hline
\end{tabular}

\section{Landgebruik}

LGN7 (Hazeu, 2014) laat zien dat het landgebruik van de polders behoorlijk verschilt (figuur 2.2). Er zijn typische akkerbouwpolders (Tweemanspolder en Wilde Veenen), stedelijke polders (Binnewegse Polder), glastuinbouwpolders (Polder Bleiswijk) en polders met voornamelijk gras (Oostpolder, Polder EGB en Zuidplaspolder-Zuid). De overige polders bevatten een mix van bovengenoemde landgebruikstypen.

\section{Grondwaterstanden (Gt-klasse)}

Voor de informatie over de Gt-klasse is gebruikgemaakt van de 1:50.000 Bodemkaart (Klijn, 1997). Voor het herschikken van de SWAP-ANIMO-rekenplots zijn de landgebruiksvormen geclusterd naar acht Gt-klassen (I t/m VIII) (figuur 2.4). Te zien is dat de veengebieden (zuidoost Schieland) een hogere grondwaterstand (lagere Gt-klasse) hebben dan de kleigebieden (noordwest Schieland).

Tabel 2.3 Het totale polderareaal en het relatieve voorkomen van landgebruikstypen.

\begin{tabular}{|c|c|c|c|c|c|c|c|}
\hline & $\begin{array}{r}\text { Bebouwd } \\
(\%)\end{array}$ & $\begin{array}{l}\text { Glastuin- } \\
\text { bouw (\%) }\end{array}$ & $\begin{array}{r}\text { Landbouw } \\
(\%)\end{array}$ & $\begin{array}{r}\text { Natuur } \\
(\%)\end{array}$ & $\begin{array}{r}\text { Stedelijk } \\
\text { groen }(\%)\end{array}$ & $\begin{array}{r}\text { Water } \\
(\%)\end{array}$ & $\begin{array}{r}\text { Totaal } \\
\text { (ha) }\end{array}$ \\
\hline Zuidplas-Zuid & 10 & 6 & 67 & 1 & 7 & 8 & 2425 \\
\hline Zuidplas-Noord & 16 & 11 & 52 & 1 & 13 & 7 & 2150 \\
\hline Binnenwegse & 43 & 0 & 10 & 2 & 38 & 7 & 1424 \\
\hline Bleiswijk & 17 & 19 & 27 & 4 & 27 & 6 & 3767 \\
\hline Wilde Veenen & 6 & 2 & 86 & 1 & 3 & 3 & 728 \\
\hline EGB & 6 & 0 & 49 & 14 & 14 & 16 & 606 \\
\hline Tweemans & 3 & 1 & 85 & 2 & 5 & 4 & 469 \\
\hline Eendragts & 10 & 1 & 21 & 1 & 36 & 31 & 1096 \\
\hline Oost & 15 & 0 & 32 & 5 & 30 & 17 & 254 \\
\hline
\end{tabular}
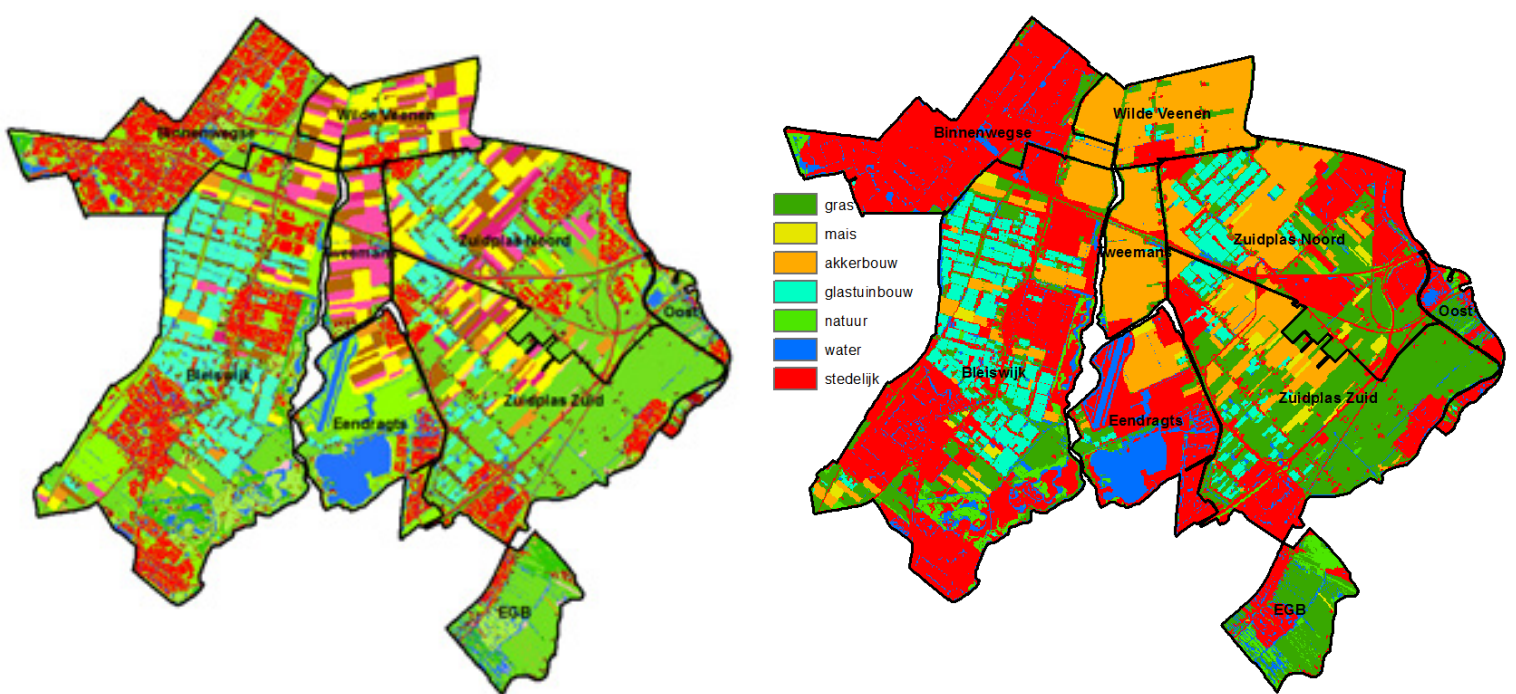

Figuur 2.2 Landgebruik volgens LGN7 (links) en geclusterd naar hoofdgebruikstypen (rechts). Voor de legenda van LGN7 wordt verwezen naar de volgende link: legenda LGN7 


\section{Bodemtype}

Voor de informatie over het bodemtype wordt bij de herschikkingsprocedure standaard gebruikgemaakt van de PAWN-bodemkaart uit 2006, waarin informatie is opgenomen over de bodemfysische kenmerken (figuur 2.3). In het studiegebied komen acht verschillende bodemfysische eenheden voor. De bodemfysische eenheden zijn tevens geclusterd naar hoofdgrondsoort: zand, klei en veen.

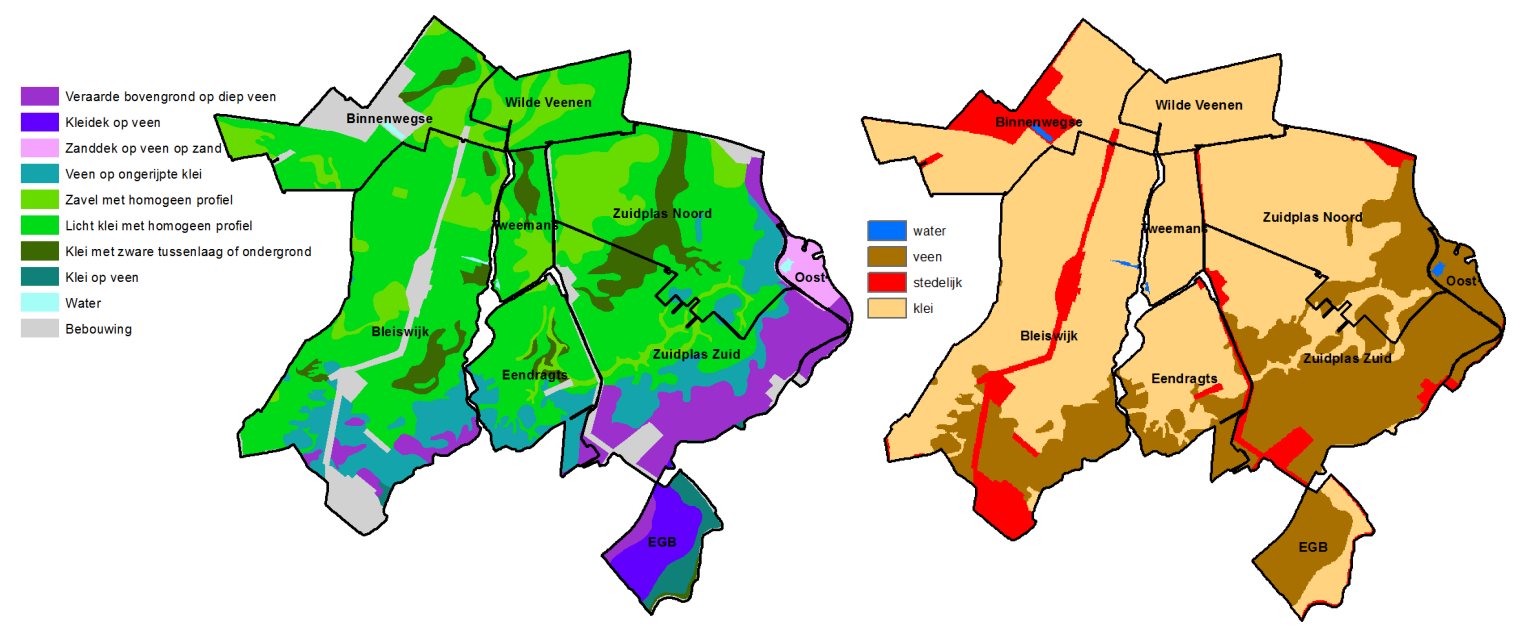

Figuur 2.3 Bodemfysische eenheden op basis van de PAWN-bodemkaart uit 2006 (links) en geclusterd naar de hoofdgrondsoorten (rechts).

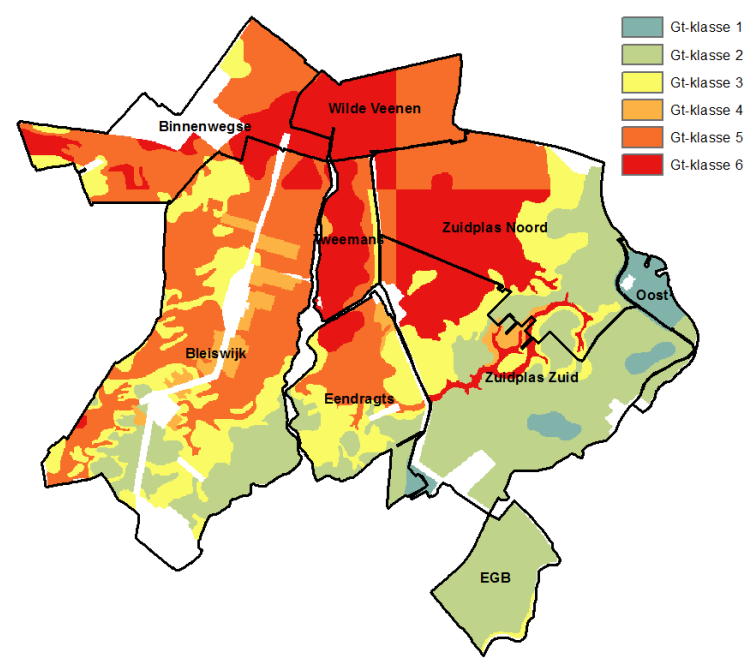

Figuur 2.4 Gt-klasse in het studiegebied.

\section{Kwel en wegzijging}

Voor informatie over de kwel en wegzijging is gebruikgemaakt van de kwelkaart van HHSK, die in 2005 is opgesteld door TNO. Het gaat om de kwel in een gemiddelde situatie in de winter en in de zomer (figuur 2.5). Te zien is dat er veel wegzijging is in de Oostpolder en in Polder EGB. Dit komt mede doordat deze polders hoger liggen dan de andere polders in Schieland. In de andere onderzochte polders is lichte tot zware kwel, in het bijzonder voor de diep gelegen Zuiplaspolder-Zuid. 


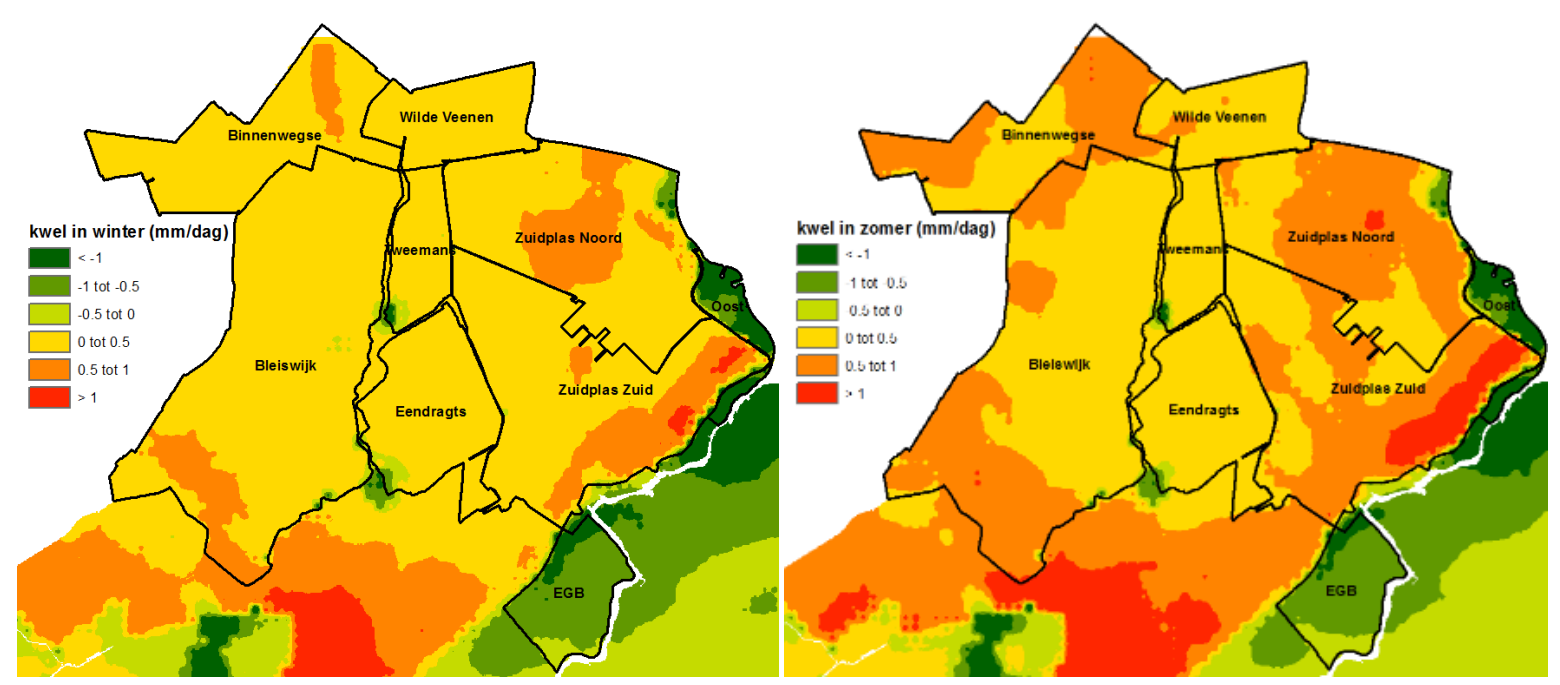

Figuur 2.5 Kwel en wegzijging in het studiegebied (bron: TNO 2005).

\section{Bodemkwaliteit}

Voor de karakterisering van de stikstof- en fosfaattoestand van de landbouwgronden is het noodzakelijk om inzicht te hebben in de fosfaat-pools, fosfaatbinding en de stikstofnalevering.

De eerste sturende factor voor $P$ is de hoeveelheid ijzer- en aluminiumoxides in de bodem (figuur 2.6). Deze bepalen de bindingscapaciteit van de bodem om fosfaat vast te houden. De hoeveelheid aluminiumoxides varieert van gemiddeld $13 \mathrm{mmol}+\mathrm{kg}^{-1}$ in de polders de Wilde Venen en Tweemanspolder, tot $91 \mathrm{mmol}+\mathrm{kg}^{-1}$ in polder EGB. De kleinste hoeveelheid ijzeroxides wordt gevonden in de polders de Wilde Venen, Tweemanspolder en de Binnenwegse Polder (met gehaltes kleiner dan $60 \mathrm{mmol}+\mathrm{kg}^{-1}$ ), terwijl de hoogste hoeveelheid gemeten is in de polders EGB, de Oostpolder en de Zuidplaspolder-Zuid. Dit kan ook consequenties hebben voor het retentievermogen in de polders, omdat gebieden met grote hoeveelheden ijzer- en aluminiumoxides hiermee de slootbodems kunnen verrijken en daarmee het fosfaatbindend vermogen van de slootbodems vergroten.
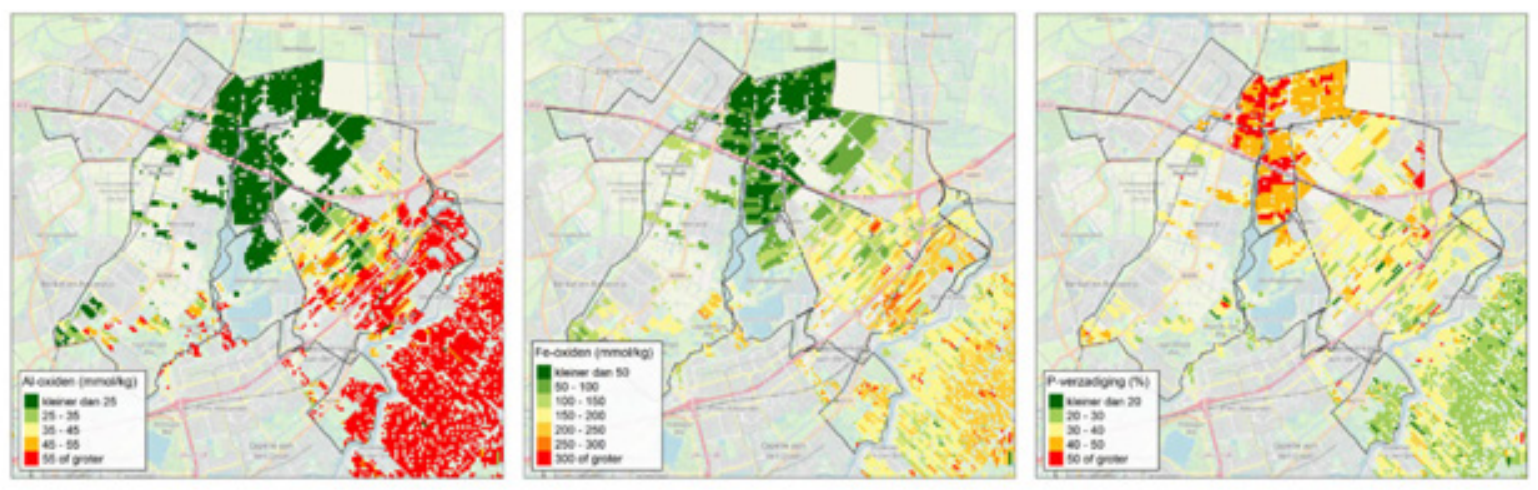

Figuur 2.6 Hoeveelheid Al- en Fe-oxides ( $\mathrm{mmol}+\mathrm{kg}^{-1}$ ) alsook de P-verzadigingsgraad (\%) van de bovengrond van agrarische percelen.

De P-verzadigingsgraad is dat deel van de bindingscapaciteit dat 'bezet' is met fosfaat. Deze parameter geeft daarmee dus een indicatie of er sprake is van fosfaatretentie in de toplaag van de bodem en wat het risico is op eventuele af- en uitspoeling vanuit de bodem. De P-verzadigingsgraad in het ontwaterde bodemprofiel neemt binnen gangbare landbouwpercelen af met de diepte. Bodems met een hoge P-verzadigingsgraad hebben een groter risico op P-verliezen, afhankelijk van of de waterflux via oppervlakkige afspoeling, drainage of ondiepe uitspoeling in het oppervlaktewater terechtkomt. Percelen met een P-verzadigingsgraad groter dan $25 \%$ voor kleigronden of $10 \%$ voor veen worden geclassificeerd als fosfaat-lekkend (Schoumans, 2004). Een fosfaat-lekkend perceel is gedefinieerd als een perceel dat nagenoeg rechtstreeks afwatert op open waterlopen en waarbij als 
gevolg van de fosfaattoestand in de bodem een verhoogde fosfaatbelasting van het oppervlaktewater optreedt (Schoumans, 2004). De gemiddelde P-verzadigingsgraad varieert tussen $28 \%$ in de polder EGB en $49 \%$ in de Binnenwegse Polder en de Tweemanspolder, waarbij de variatie binnen de polders groter is dan de variatie tussen de polders.

De fosfaattoestand van de bodem geeft aan of er voldoende fosfaat in de bodem zit voor een optimale gewasproductie en wordt gebruikt in zowel bemestingsadviezen als de mestwetgeving. Afhankelijk van de hoeveelheid fosfaat wordt een bodem vervolgens geclassificeerd als een toestand 'arm', 'laag', 'neutraal' of 'hoog'. Deze P-toestand bepaalt hoeveel dierlijke mest er mag worden toegediend.

De P-voorraad gemeten via een extractie met ammonium-lactaat is relatief hoog in vrijwel alle polders: de gemiddelde PAL is met $39 \mathrm{mg} \mathrm{P}_{2} \mathrm{O}_{5} 100 \mathrm{~g}^{-1}$ het laagst in de polder EGB, maar ligt voor alle overige polders hoger dan $50 \mathrm{mg} \mathrm{P}_{2} \mathrm{O}_{5} 100 \mathrm{~g}^{-1}$ (figuur 2.7). Dit betekent dat er sprake is van een hoge P-toestand, en de toegestane bemesting is daardoor lager dan de gewasopname. Voor de P-voorraad gemeten via een waterextractie is er sprake van een grotere variatie binnen en tussen polders: polder EGB heeft met gemiddeld $21 \mathrm{mg} \mathrm{P}_{2} \mathrm{O}_{5} 100 \mathrm{ml}^{-1}$ de laagste waarde, terwijl de gemiddelde Pw voor alle andere polders varieert van 31 tot $47 \mathrm{mg} \mathrm{P}_{2} \mathrm{O}_{5} 100 \mathrm{ml}^{-1}$. Met uitzondering van de polders de Wilde Venen, Binnenwegse Polder, Zuidplaspolder-Noord en de Tweemanspolder, ligt de Pw-waarde voor de overige polders in de toestandsklasse laag: op bouwlandpercelen met de toestandsklasse laag mag bemest worden om de P-toestand van de percelen te verhogen.
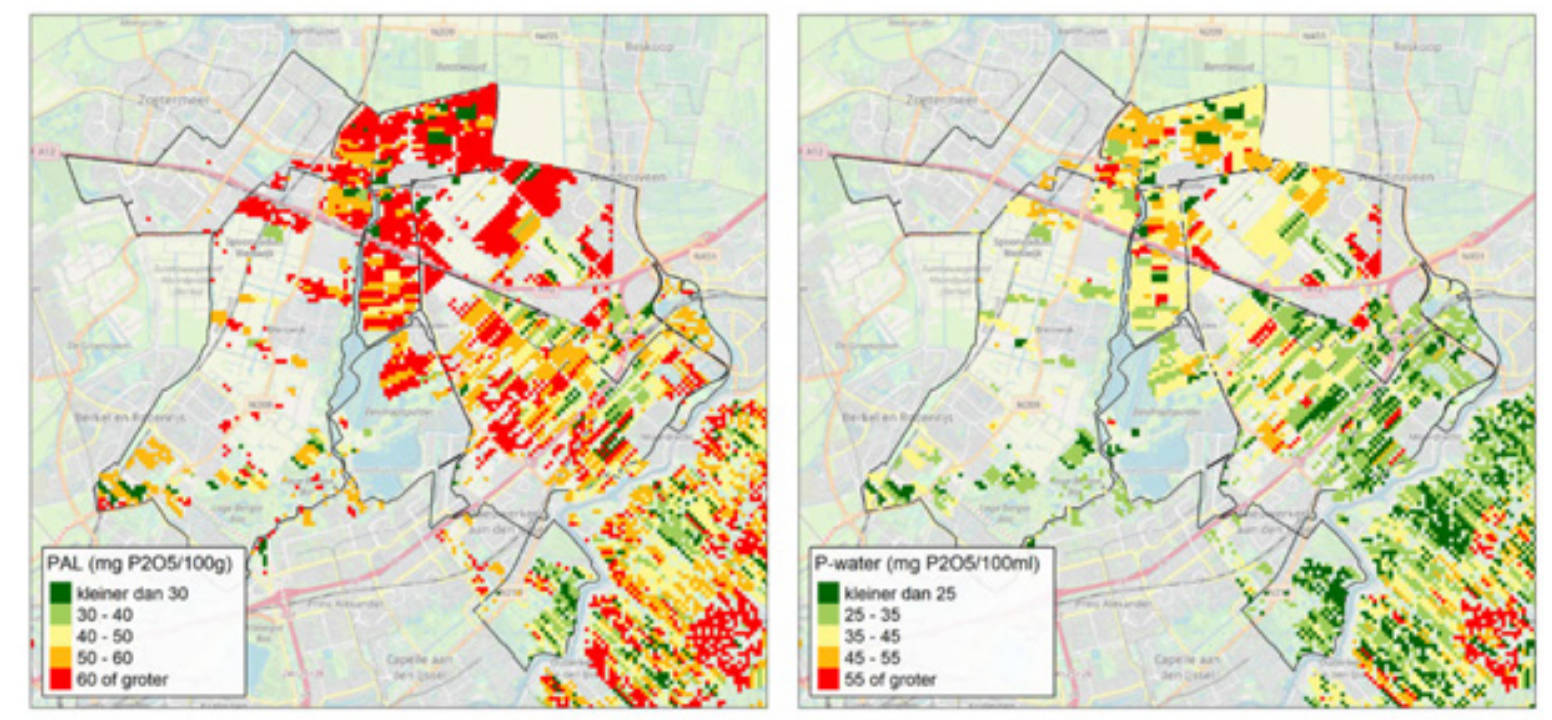

Figuur 2.7 Ruimtelijke variatie in de voorraad van fosfaat in de bouwvoor, gemeten via een extractie met ammonium-lactaat ( $P A L$, links) en een waterextractie ( $P$-water, rechts).

De P-concentratie in de bodemoplossing, gemeten via een extractie met 0,01M

$\mathrm{CaCl}_{2}$ alsook de daarvan afgeleide bufferindex - die aangeeft in welke mate de bodem de

P-concentratie in de bodemoplossing in stand kan houden - worden weergegeven in figuur 2.8. 

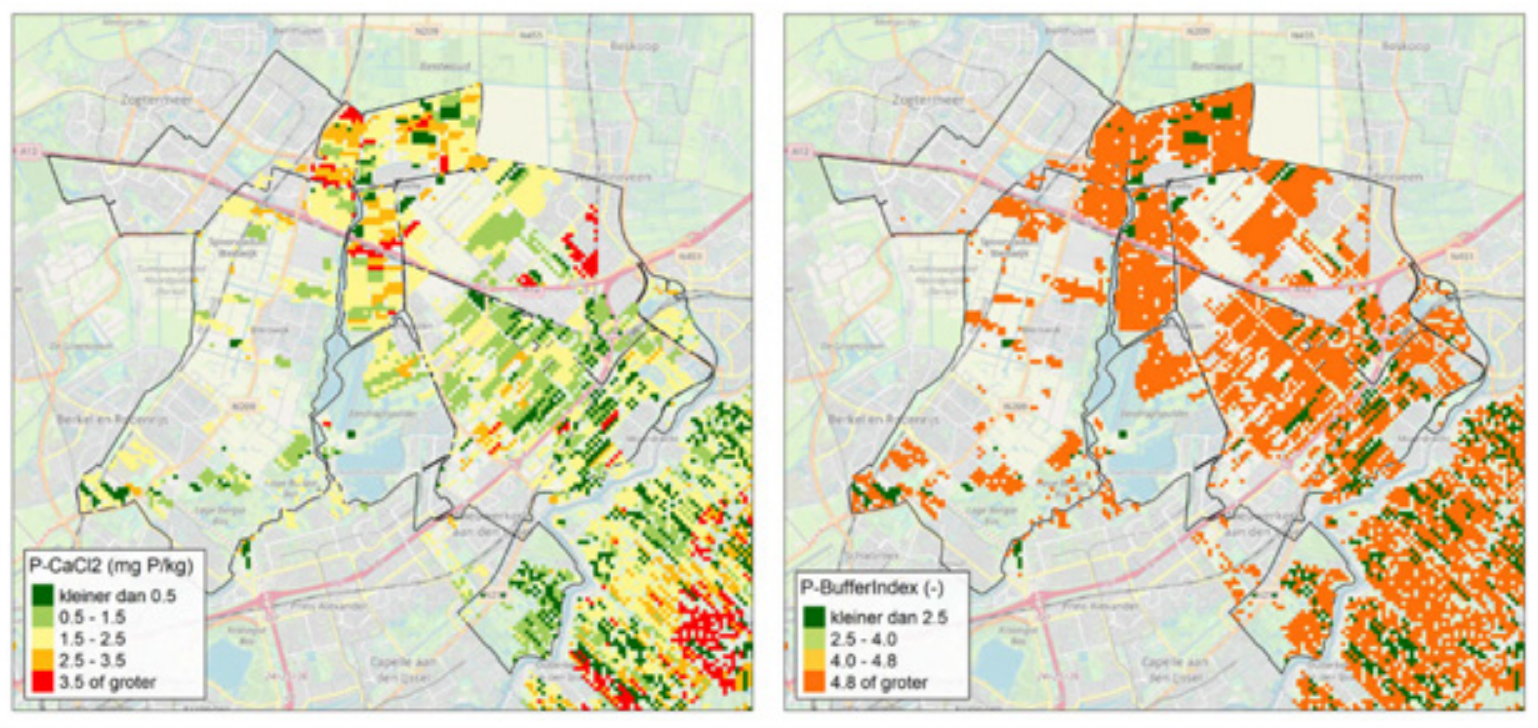

Figuur 2.8 Ruimtelijke variatie in de $P$-concentratie van de bodemlossing en de $P$-bufferindex.

De hoogste gemiddelde concentraties komen voor in de Binnenwegse Polder, de Wilde Venen en de Polder Bleiswijk (allemaal groter dan 2,1 $\mathrm{mg} \mathrm{P} \mathrm{kg}^{-1}$ ). De laagste concentratie komt voor in de polder EGB. De ruimtelijke variatie binnen de polders is aanzienlijk, in het bijzonder voor de Binnenwegse Polder, de Wilde Venen en de Tweemanspolder.

Fundamenteel onderzoek gestart in 2003 door Wageningen Universiteit en NMI geeft aan dat de P-buffering van de bodem goed in beeld kan worden gebracht door rekening te houden met zowel de P-voorraad als de P-concentratie in de bodemoplossing (Bussink, 2011; Van Rotterdam \& Bussink, 2016). De hieruit afgeleide fosfaatbufferindex (PBI) geeft aan hoe goed een bodem in staat is de $\mathrm{P}$-concentratie op evenwicht te houden, en wordt in figuur 2.8 weergegeven vanuit de agronomische beoordeling voor grasgroei. Gemiddeld is de P-buffering in de polders de Wilde Veenen, de Binnenwegse Polder en de Tweemanspolder dermate hoog $(>4,8)$ dat er geen P-bemesting nodig is voor een goede gewasgroei. Er zijn vrijwel geen percelen binnen het hele beheergebied die in de situatie terechtkomen dat er een groot tekort aan P dreigt; de P-buffering is veelal optimaal dan wel verhoogd.

De gemiddelde voorraad organische stof (OS) neemt toe van gemiddeld 2 à $3 \%$ in de polders De Wilde Veenen en de Tweemanspolder tot 5 à $6 \%$ in de Binnenwegse Polder en de Eendragtspolder en tot groter dan 16 à 20\% in de polders Zuidplaspolder-Zuid, EGB en Oostpolder (figuur 2.9). Organische stof heeft belangrijke functies in de bodem en is van directe invloed op de bodemvruchtbaarheid. Het verbetert de structuur, bevordert de bewerkbaarheid en verhoogt op schrale zandgronden het vochtvasthoudend vermogen. Het effect zal echter op de klei- en veenbodems van de hier beschouwde polders waarschijnlijk niet groot zijn. Daarnaast zorgt OS voor extra kation-omwisselcapaciteit, waardoor meer kationen als kalium, calcium en magnesium kunnen worden vastgehouden. De OS bevat daarnaast ook zelf nutriënten als stikstof, fosfor en zwavel, die na afbraak beschikbaar komen voor gewasopname. De huidige landbouwpraktijk streeft naar een positieve OS-balans waarbij de afbraak van OS in de bodem wordt gecompenseerd via de aanvoer van gewasresten, compost en organische mest. 

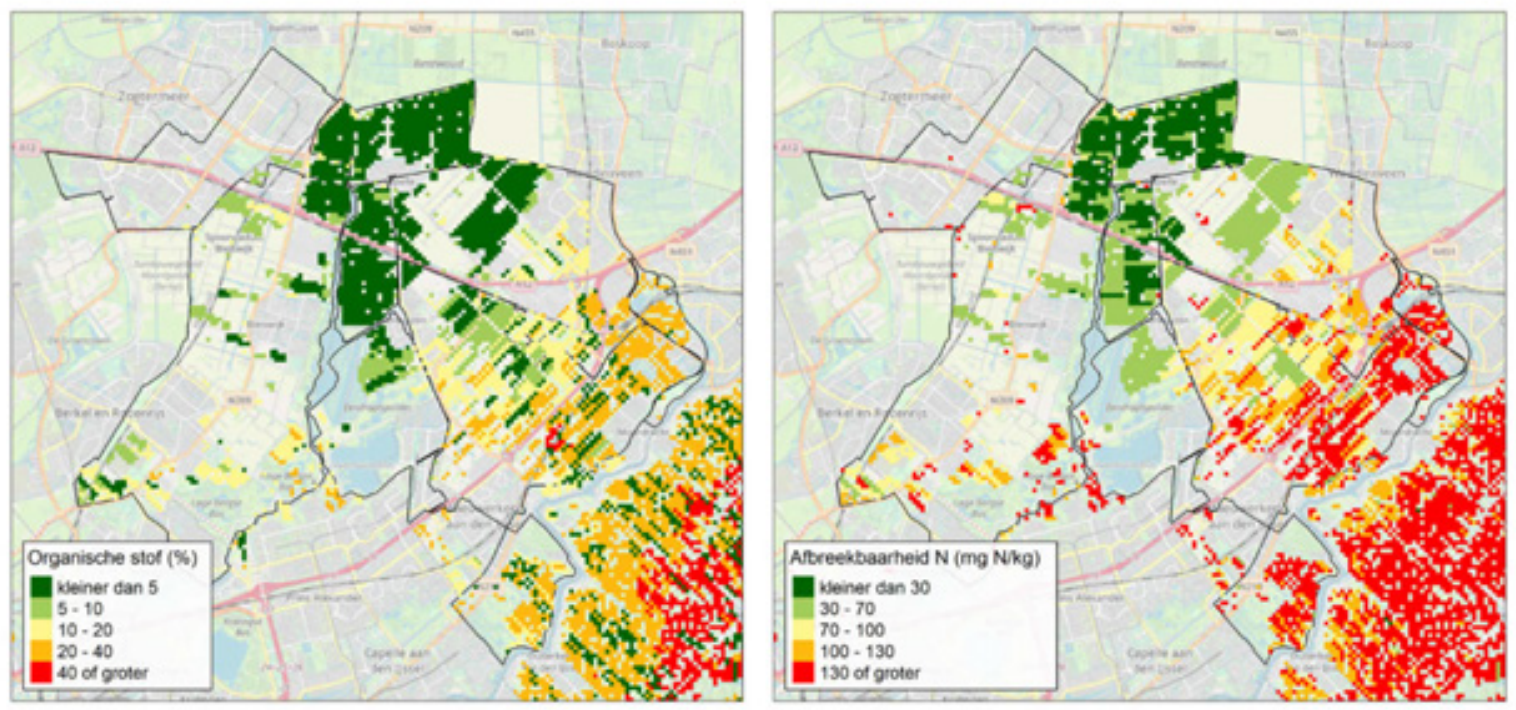

Figuur 2.9 Ruimtelijke variatie in het organische stofgehalte (\%) en potentiële afbreekbaarheid van de organische stikstof ( $N$-mineralisatiesnelheid, $m g \mathrm{Ng}^{-1} 10 \mathrm{~d}^{-1}$ ).

De afbreekbaarheid van de organische stikstof wordt bepaald via een anaerobe incubatieproef, waarbij grondmonsters 10 dagen bij een temperatuur van 40 graden Celsius worden opgeslagen onder anaerobe omstandigheden. De toename van ammonium geeft vervolgens een indicatie van de activiteit van het bodemleven, en daarmee ook van de kwaliteit van de organische $\mathrm{N}$ in de bodem. Bodems met een hoge afbreekbare hoeveelheid $\mathrm{N}$ worden gekenmerkt door een hoge natuurlijke $\mathrm{N}$-levering en door hogere $\mathrm{N}$-verliezen gedurende de winterperiode. De N-levering neemt toe van $<50 \mathrm{mg} \mathrm{N} \mathrm{kg}^{-1}$ in de polders De Wilde Veenen, de Tweemanspolder en de Binnenwegste Polder tot $>100 \mathrm{mg} \mathrm{N} \mathrm{kg}^{-1}$ in de ZuidplaspolderZuid, EGB en de Oostpolder. Bodems met een rijk bemestingsverleden hebben in de praktijk een hogere afbreekbaarheid dan bodems die weinig drijfmest hebben ontvangen.

\subsection{Bepalen af- en uitspoeling van nutriënten}

Om de af- en uitspoeling van nutriënten te berekenen, is gebruikgemaakt van SWAP-ANIMO-rekenplots die via een herschikkingsprocedure (Van Boekel, 2013) zijn geregionaliseerd. In deze paragraaf wordt de herschikkingsprocedure kort beschreven; een uitgebreidere beschrijving is te vinden in bijlage 1.

\section{Gebiedsanalyse}

De eerste stap in de herschikkingsprocedure is het genereren van een zogenaamde MLBG-kaart op basis van de gebiedskenmerken ( kaarten zijn hierbij gebruikt (zie ook figuur $2.2 \mathrm{t} / \mathrm{m} \mathrm{2.5):}$

- Meteodistricten op basis van PAWN-districten (Kroes, 1999; Kroon, 2001)

- Landgebruik op basis van het LGN7-bestand (Hazeu, 2014)

- Bodemtype op basis van de 1:50.000 Bodemkaart (Klijn, 1997)

- Gt-klasse op basis van de 1:50.000 Bodemkaart (Klijn, 1997)

De verschillende kaartlagen zijn gecombineerd tot één kaartlaag met unieke MLBG-eenheden met een resolutie van 25-25m. Deze MLBG-kaart is de input voor de tweede stap van de herschikkingsprocedure (selectieprocedure).

\section{Selectieprocedure rekenplots}

In de tweede stap zijn voor alle MLBG-eenheden representatieve rekenplots gezocht. Bij de zoektocht naar representatieve rekenplots kunnen zich meerdere situaties voordoen:

1. Er worden meerdere representatieve rekenplots per eenheid gevonden;

2. Er wordt één representatieve rekenplot gevonden;

3. Er kunnen geen rekenplots gevonden worden die voldoen aan de opgelegde criteria. 
Situatie 1: Wanneer er sprake is van meerdere representatieve rekenplots wordt een gemiddelde afen uitspoeling naar het oppervlaktewater berekend.

Situatie 2: Indien er één rekenplot gevonden kan worden, worden de berekende af- en uitspoeling van deze plot toegekend aan een MLBG-eenheid.

Situatie 3: Indien er geen representatieve rekenplots gevonden worden, omdat de gewenste combinatie landgebruik, bodemfysische eenheid en Gt-klasse binnen een meteodistrict niet voorkomt, is ervoor gekozen om stapsgewijs steeds meer informatie van de MLBG-eenheden los te laten, net zolang totdat alle eenheden zijn voorzien van een koppeling aan STONE-plots. Het stappenplan voor de toekenning van STONE-plots aan MLBG-eenheden is beschreven in bijlage 1 . In de zoektocht naar representatieve rekenplots bij geen fit is voor landgebruik, bodemtype, GT en meteoregio-combinatie gezocht naar rekenplots met redelijk vergelijkbare bodemtypen en redelijk vergelijkbare GT's. De aansluiting op de onderscheiden klassen qua landgebruik en meteoregio wordt in de selectieprocedure niet losgelaten (harde criteria). Nadat alle stappen zijn doorlopen, is het mogelijk om aan elke MLBGeenheid een stikstof- en fosforvracht toe te kennen.

\subsection{Opstellen stofbalansen en toetsing}

Voor de periode 2000-2013 zijn stofbalansen per jaar opgesteld voor stikstof $(N)$ en fosfor (P) conform de ECHO-methodiek (Kroes, 2011). Tabel 2.4 geeft een overzicht van de verschillende posten van de stoffenbalans en de informatie die is gebruikt om deze posten te bepalen.

Tabel 2.4 Overzicht balanstermen en informatiebronnen voor het opstellen van stofbalansen.

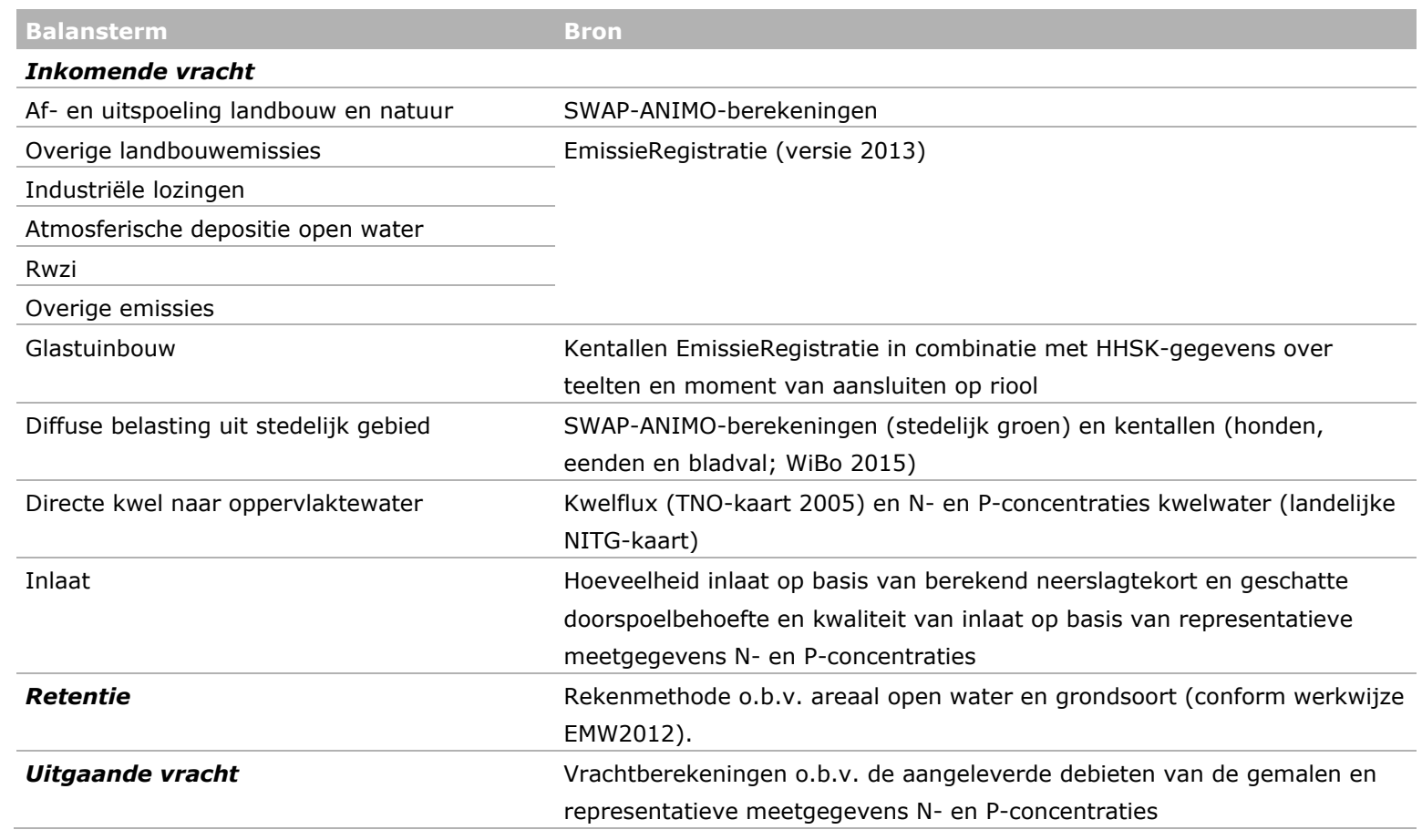

Bij deze bepaling is voor enkele posten afgeweken van de ECHO-methodiek. Het gaat om de posten 'Glastuinbouw', 'Diffuse belasting stedelijk gebied', 'Directe kwel naar oppervlaktewater' en 'Inlaat'. Details per balanspost worden hierna in de paragraaf behandeld. De paragraaf sluit af met de wijze waarop de opgestelde nutriëntenbalans is getoetst aan de uit metingen af te leiden nutriëntenvracht. 


\section{Af- en uitspoeling}

Voor het afleiden van de af- en uitspoeling van stikstof en fosfor uit landbouw- en natuurgronden in de periode 2000-2013 is gebruikgemaakt van bestaande SWAP-ANIMO-berekeningen, die zijn uitgevoerd in het kader van de Evaluatie Meststoffenwet 2016 (Grinsven 2017). Op basis van de herschikkingsmethode (paragraaf 2.3) zijn de representatieve SWAP-ANIMO-plots geselecteerd.

\section{Emissieregistratie}

De EmissieRegistratie is de landelijke database waarin de emissies naar bodem, water en lucht voor veel beleidsrelevante stoffen per emissiebron zijn vastgelegd om (inter)nationale rapportageverplichtingen te kunnen nakomen (www.Emissieregistratie.nl). De EmissieRegistratie omvat gegevens van puntbronnen en diffuse bronnen voor de periode vanaf 1990. Emissiebronnen die bijdragen aan de stikstof- en fosforbelasting van het oppervlaktewater zijn in de EmissieRegistratie toegekend aan 34 subdoelgroepen, die vervolgens geclusterd zijn tot 13 doelgroepen (bijlage 2). Bijlage 3 geeft een overzicht van de bronnen waar in de EmissieRegistratie emissies voor nutriënten naar water worden berekend en een overzicht van de indicaties van de betrouwbaarheid van de emissieschattingen.

Conform de ECHO-methodiek worden de doelgroepen geclusterd tot 6 groepen (zie tabel B2.1):

- LO: overige landbouwemissies (meemesten sloten, afvalwater glastuinbouw, erfafspoeling);

- DW: atmosferische depositie open water;

- EF: rioolwaterzuiveringsinstallaties (rwzi's);

- IND: industriële lozingen;

- OV: overige lozingen (o.a. verkeer, huishoudelijk afval, overige emissies);

- UA: uit- en spoeling vanuit landbouw- en natuurgronden.

Voor het vaststellen van de nutriëntenbelasting van het oppervlaktewater vanuit bovenstaande bronnen is gebruikgemaakt van de EmissieRegistratie versie 2013. Uitzondering hierop zijn de af- en uitspoeling vanuit landbouw- en natuurgronden. De nutriëntenbelasting vanuit landbouw- en natuurgronden is via de herschikkingsmethode (paragraaf 2.3) afgeleid.

Verder is een verfijndere aanpak gekozen voor atmosferische depositie en voor de glastuinbouw. De glastuinbouw is niet overgenomen uit de EmissieRegistratie, maar is bepaald met regionale gegevens (zie volgende onderdeel). De atmosferische depositie is bijgesteld op basis van het oppervlak aan open water. Dit is gedaan, omdat de EmissieRegistratie de hoeveelheid open water onderschat (zie tabel 2.5). Het open water areaal is overgenomen uit gegevens van HHSK (zie tabel 2.3). De uiteindelijke belasting $(\mathrm{kg} \mathrm{N})$ is bepaald door dit areaal te vermenigvuldigen met de $\mathrm{N}$-depositie per eenheid oppervlak waarvoor $18.7 \mathrm{kgN} / \mathrm{ha}$ is aangenomen. Dit getal is de gemiddelde atmosferische depositie volgens de EmissieRegistratie in de periode 2000-2015.

Tabel 2.5 Openwateroppervlak voor vier van de onderzochte polders volgens de EmissieRegistratie (ER) en volgens regionale gegevens (HHSK).

\begin{tabular}{lccc} 
& Openwateroppervlak (ha) & $\begin{array}{c}\text { Verhouding openwater- } \\
\text { oppervlak (\%) ten opzichte van } \\
\text { gegevens ER }\end{array}$ & HHSK \\
\hline Polder Bleiswijk & ER & HHSK & $147 \%$ \\
\hline Eendragtspolder & 178 & 262 & $161 \%$ \\
\hline Zuidplaspolder-Noord & 214 & 345 & $512 \%$ \\
\hline Zuidplaspolder-Zuid & 30 & 155 & $380 \%$ \\
\hline
\end{tabular}

\section{Glastuinbouw}

De nutriëntenbelasting vanuit de glastuinbouw is niet overgenomen uit de EmissieRegistratie, maar is bepaald met regionale gegevens. Dit is gedaan omdat glastuinbouw veel voorkomt in de onderzochte polders en omdat gebiedsexperts aangaven dat de EmissieRegistratie de bijdrage van de glastuinbouw onderschat. 
De nutriëntenbelasting vanuit de glastuinbouw is berekend door gebruik te maken van HHSKgegevens over de aanwezige teelten in de verschillende polders (tabel 2.6). Daarna is het totale oppervlak per teelt bepaald met het glastuinbouwareaal volgens LGN7 (tabel 2.3). Dit glastuinbouwareaal komt goed overeen met het areaal volgens de Basisregistratie Gewaspercelen (BRP). Aangenomen is dat het glastuinbouwareaal van Polder Bleiswijk is toegenomen in de loop der tijd, zoals aangegeven door HHSK. Voor de periode 2000-2004 is gewerkt met een areaal van 575 ha, voor 2005 van 625 ha en voor 2006-nu van 675 ha.

Vervolgens is de nutriëntenbelasting per teelt bepaald met kentallen uit de EmissieRegistratie (tabel 2.7) en zijn deze belasting geaggregeerd tot de totale nutriëntenbelasting per polder. Als laatste stap is gekeken welk deel van deze nutriëntenbelasting daadwerkelijk in het oppervlaktewater belandt. Grofweg zijn er drie afvoerroutes van nutriënten: 1) directe lozing op oppervlaktewater, 2) verliezen naar de bodem en 3) afvoer via het riool. Voor 2010 was de glastuinbouw nog niet aangesloten op het riool (zie tabel 2.8) en waren alleen afvoerroute 1 en 2 van belang. Aangenomen is dat niet alleen de nutriënten van route 1 , maar ook die van route 2 uiteindelijk in het oppervlaktewater terechtkomen. Oftewel, zonder rioolaansluiting komt de gehele nutriëntenbelasting in het oppervlaktewater. Na rioolaansluiting (vanaf 2010) is aangenomen dat een bepaald deel van de nutriëntenbelasting niet in het oppervlaktewater komt, maar wordt afgevoerd via het riool. Voor grondgebonden teelt is op basis van expert judgement (Theo Cuijpers HHSK en Ronald Bakkum Hoogheemraadschap Delfland) aangenomen dat 40\% wordt afgevoerd via het riool en de overige $60 \%$ in het oppervlaktewater terechtkomt. Voor de substraatteelt is $80 \%$ rioolafvoer aangenomen en $20 \%$ oppervlaktewaterafvoer. Voor substraatteelt wijkt deze rioolafvoer af van die van de EmissieRegistratie (die 95\% rioolafvoer hanteert).

Tabel 2.6 Glastuinbouwteelten uitgedrukt als percentage van het glastuinbouwareaal (bron: HHSK).

\begin{tabular}{|c|c|c|c|c|c|c|c|c|}
\hline Type teelt & Gewas & $\begin{array}{r}\text { Bleis- } \\
\text { wijk }\end{array}$ & Oost & $\begin{array}{c}\text { Twee- } \\
\text { mans }\end{array}$ & $\begin{array}{l}\text { Een- } \\
\text { dragts }\end{array}$ & $\begin{array}{r}\text { Wilde } \\
\text { Veenen }\end{array}$ & $\begin{array}{r}\text { Zuidplas } \\
\text { Noord }\end{array}$ & $\begin{array}{r}\text { Zuidplas } \\
\text { Zuid }\end{array}$ \\
\hline \multirow[t]{8}{*}{ Substraat } & Perkplanten & $2 \%$ & & & $11 \%$ & & & $3 \%$ \\
\hline & Anthurium & $2 \%$ & & & & $21 \%$ & $7 \%$ & \\
\hline & Gerbera & $1 \%$ & & & & & $9 \%$ & $19 \%$ \\
\hline & Rozen & $3 \%$ & & & & $14 \%$ & $18 \%$ & $8 \%$ \\
\hline & Aubergines & $1 \%$ & & & & & & $1 \%$ \\
\hline & Aardbei & $1 \%$ & & & & & & \\
\hline & Komkommers & $5 \%$ & & & & & & $2 \%$ \\
\hline & Overig substraat & $6 \%$ & & & $80 \%$ & $17 \%$ & $13 \%$ & $15 \%$ \\
\hline \multirow[t]{2}{*}{ Grondgebonden } & Chrysant & $2 \%$ & & & & & & \\
\hline & Overig grondteelt & $4 \%$ & & & & & $3 \%$ & \\
\hline
\end{tabular}


Tabel 2.7 Nutriëntenbelasting oppervlaktewater van glastuinbouwteelten (bron: EmissieRegistratie 2016).

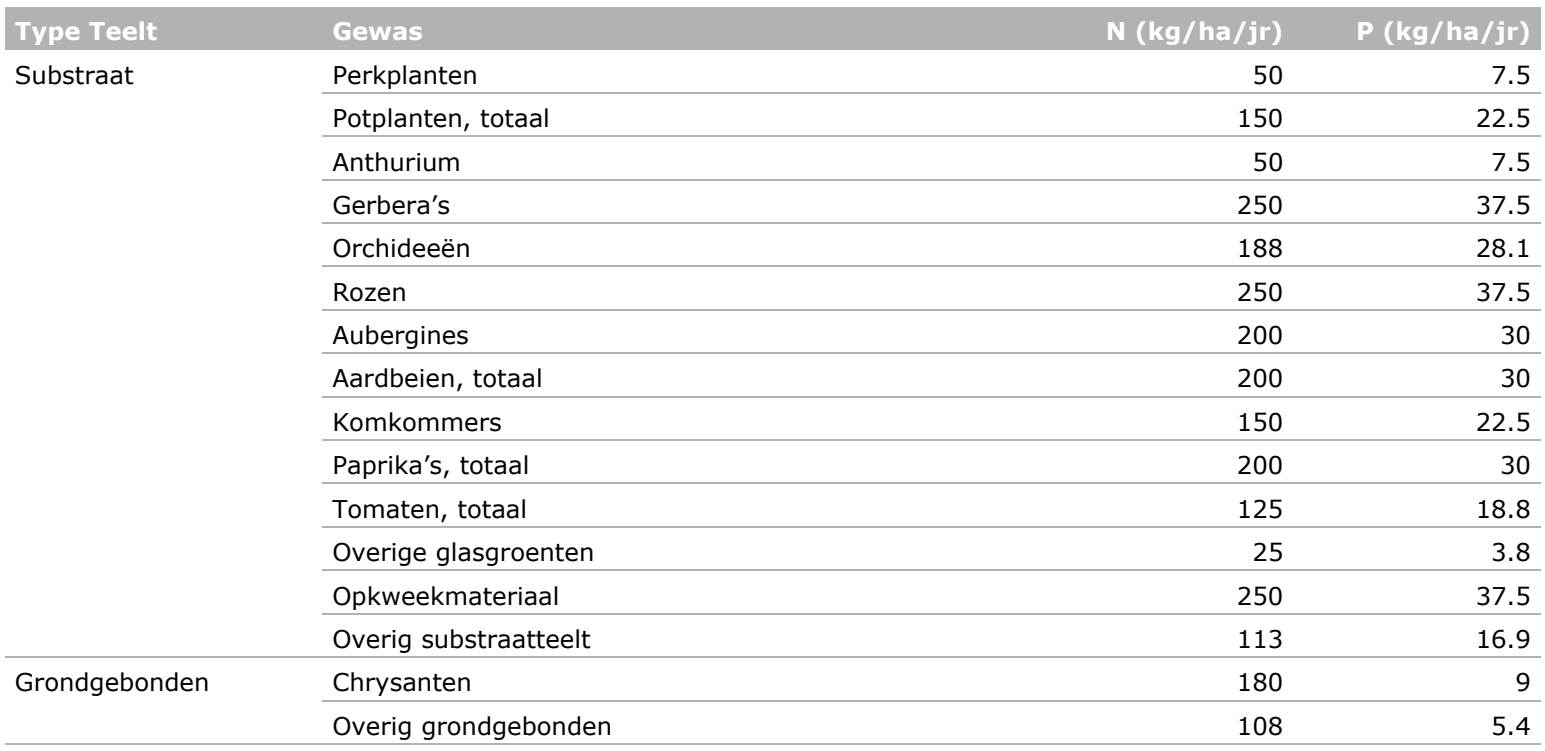

Tabel 2.8 Deel van de glastuinbouw dat is aangesloten op het riool (bron: HHSK).

\begin{tabular}{lrrrrrrr} 
& 2009 en daarvor & 2010 & 2011 & 2012 & 2013 & 2014 \\
Wilde Veenen & $0 \%$ & $50 \%$ & $100 \%$ & $100 \%$ & $100 \%$ & $100 \%$ & $100 \%$ \\
\hline Binnenwegse Polder & $0 \%$ & $50 \%$ & $100 \%$ & $100 \%$ & $100 \%$ & $100 \%$ & $100 \%$ \\
\hline Polder Bleiswijk & $0 \%$ & $0 \%$ & $0 \%$ & $0 \%$ & $0 \%$ & $50 \%$ & $100 \%$ \\
\hline Tweemanspolder & $0 \%$ & $50 \%$ & $100 \%$ & $100 \%$ & $100 \%$ & $100 \%$ & $100 \%$ \\
\hline Oostpolder & $0 \%$ & $50 \%$ & $100 \%$ & $100 \%$ & $100 \%$ & $100 \%$ & $100 \%$ \\
\hline EGB & $0 \%$ & $50 \%$ & $100 \%$ & $100 \%$ & $100 \%$ & $100 \%$ & $100 \%$ \\
\hline Eendrachtspolder & $0 \%$ & $50 \%$ & $100 \%$ & $100 \%$ & $100 \%$ & $100 \%$ & $100 \%$ \\
\hline Zuidplaspolder-Noord & $0 \%$ & $50 \%$ & $100 \%$ & $100 \%$ & $100 \%$ & $100 \%$ & $100 \%$ \\
\hline Zuidplaspolder-Zuid & $0 \%$ & $50 \%$ & $100 \%$ & $100 \%$ & $100 \%$ & $100 \%$ & $100 \%$ \\
\hline
\end{tabular}

\section{Diffuse belasting uit stedelijk gebied}

De emissies vanuit het stedelijk gebied zijn niet volledig gedekt door de EmissieRegistratie (ER). De ER houdt wel rekening met de bijdrage van regenwaterriolen en overstorten (deze bijdrage zit in de term 'overige bronnen'), maar houdt geen rekening met de nutriëntenbelasting vanuit stedelijk groen via bronnen als honden, eenden en bladval. Deze bronnen zijn daarom aanvullend bepaald in deze studie en benoemd als 'diffuse belasting uit stedelijk gebied'.

Voor stedelijk groen is aangenomen dat deze dezelfde af- en uitspoeling hebben als een SWAPANIMO-rekenplot voor natuur. Voor de belasting via honden, eenden en bladval is aangesloten op kentallen voor 'gemiddeld stedelijk gebied' (WiBo, 2015). Deze zijn uitgedrukt per areaal stedelijk water en bedragen $0,25 \mathrm{gP} / \mathrm{m}^{2} /$ jaar en $0,36 \mathrm{gN} / \mathrm{m}^{2} / \mathrm{jaar}$ voor eenden, $0,25 \mathrm{gP} / \mathrm{m}^{2} / \mathrm{jaar}$ en $0,40 \mathrm{gN} / \mathrm{m}^{2} / \mathrm{jaar}$ voor honden en $0,24 \mathrm{gP} / \mathrm{m}^{2} / \mathrm{jaar}$ en $2,75 \mathrm{gN} / \mathrm{m}^{2} / \mathrm{jaar}$ voor bladval. Het oppervlak aan stedelijk water is bepaald door aan te nemen dat $5 \%$ van het totale stedelijk oppervlak (= stedelijk verhard + stedelijk groen) bestaat uit stedelijk water.

Directe kwel naar oppervlaktewater

Directe kwel op waterlopen mist in de EmissieRegistratie, maar kan toch een significante nutriëntenbron zijn, met name in grotere en diepere waterlopen. Daarom is deze bron aanvullend bepaald in dit onderzoek. Dit is gedaan door eerst per polder de gemiddelde jaarlijkse kwelflux te bepalen op basis van de HHSK-kwelkaarten voor de zomer en de winter (figuur 2.5). Daarna is gekeken hoeveel van deze kwel direct in de waterlopen terechtkomt door deze kwelflux te vermenigvuldigen met het oppervlak aan open water. Als laatste stap is de nutriëntenbelasting via 
directe kwel berekend door deze kwelhoeveelheid te vermenigvuldigen met de kwaliteit van het kwelwater zoals deze berekend wordt in het Stone-model.

Inlaat

De nutriëntenbelasting via inlaatwater wordt in de ECHO-methodiek normaal gesproken bepaald met metingen van de inlaathoeveelheden en metingen van de kwaliteit van dit inlaatwater. Metingen van de inlaathoeveelheid missen echter, ook omdat het vrijwel onmogelijk is om alle inlaten (die vaak verlopen via particuliere inlaten) te meten. Daarom is ervoor gekozen de hoeveelheid inlaatwater te berekenen. Dit is gedaan in twee stappen. In de eerste stap is gekeken hoeveel inlaatwater er nodig is voor peilhandhaving. In de tweede stap is deze inlaatbehoefte op basis van expert judgement opgehoogd met een doorspoelbehoefte.

De inlaatbehoefte voor peilhandhaving (stap 1 ) is als volgt bepaald:

$$
\text { inlaat }_{\text {peilhandhaving }}=\text { infiltratie }_{S W A P-A N I M O}+\text { wegzijging }_{\text {direct }}-(N-E)_{\text {openwater }}
$$

Hierbij staat infiltratie voor het water dat vanuit de waterloop infiltreert naar de bodem (gestippelde pijl in figuur 2.10; de tegenhanger van uitspoeling), wegzijging heeft betrekking op de directe wegzijging van de waterloop, $\mathrm{N}$ staat voor neerslag op het open water en $\mathrm{E}$ voor verdamping op het open water. De infiltratie is bepaald op 10-daagse basis met de SWAP-Animo-rekenplots (inclusief stedelijk groen), de kwel/wegzijging volgt uit de HHSK-kwelkaart (figuur 2.5) en de verdamping en neerslag op open water volgt uit KNMI-gegevens van meteostation Rotterdam. Zo is voor elke 10 dagen bepaald of er een wateroverschot of een watertekort is. De watertekorten zijn opgeteld voor het hele jaar om te komen tot een totaal watertekort per polder per jaar. Dit is de inlaatbehoefte voor peilhandhaving.

De doorspoelbehoefte is afgeleid op basis van de totale hoeveelheid water die is ingelaten vanuit buitenwater op boezem. Debietmetingen van HHSK geven aan dat er op dagen met een watertekort gemiddeld $0,3 \mathrm{~m}^{3} / \mathrm{s}$ wordt ingelaten vanuit de Nieuwe Maas op de Rotteboezem (via inlaat 1 in figuur 2.1) en $0,5 \mathrm{~m}^{3} / \mathrm{s}$ op de Ringvaart vanuit de Hollandse IJssel (via inlaat 2 in figuur 2.1). Deze inlaathoeveelheid is vervolgens areaal-gewogen verdeeld over de polders die zijn aangetakt op het boezemstelsel. Tabel 2.9 geeft de resulterende totale inlaatbehoefte per polder. Een deel van deze inlaatbehoefte bestaat uit de in de vorige stap berekende waterinlaat voor peilhandhaving. Het resterende deel is toegekend aan doorspoelen. Deze doorspoelbehoefte is dus berekend met de inlaatbehoefte voor peilhandhaving en het aantal dagen met een watertekort, zodanig dat aan de totale inlaatbehoefte wordt voldaan.

Tabel 2.9 Gemiddelde dagelijkse inlaatbehoefte per polder bij watertekort.

\begin{tabular}{llrr} 
Polder & Inlaatgebied & Aandeel van inlaatgebied (\%) & Inlaatbehoefte (m3/s) \\
Polder De Wilde Veenen & Rotte & 7 & 0.021 \\
\hline Binnenwegse Polder & Rotte & 14 & 0.041 \\
\hline Polder Bleiswijk & Rotte & 36 & 0.108 \\
\hline Tweemanspolder & Rotte & 4 & 0.013 \\
\hline Oostpolder & Ringvaart & 3 & 0.015 \\
\hline Polder EGB & Ringvaart & 7 & 0.035 \\
\hline Eendragtspolder & Rotte & 10 & 0.031 \\
\hline Zuidplaspolder-Noord & Ringvaart & 25 & 28 \\
\hline Zuidplaspolder-Zuid & Ringvaart & 0.126 \\
\hline
\end{tabular}




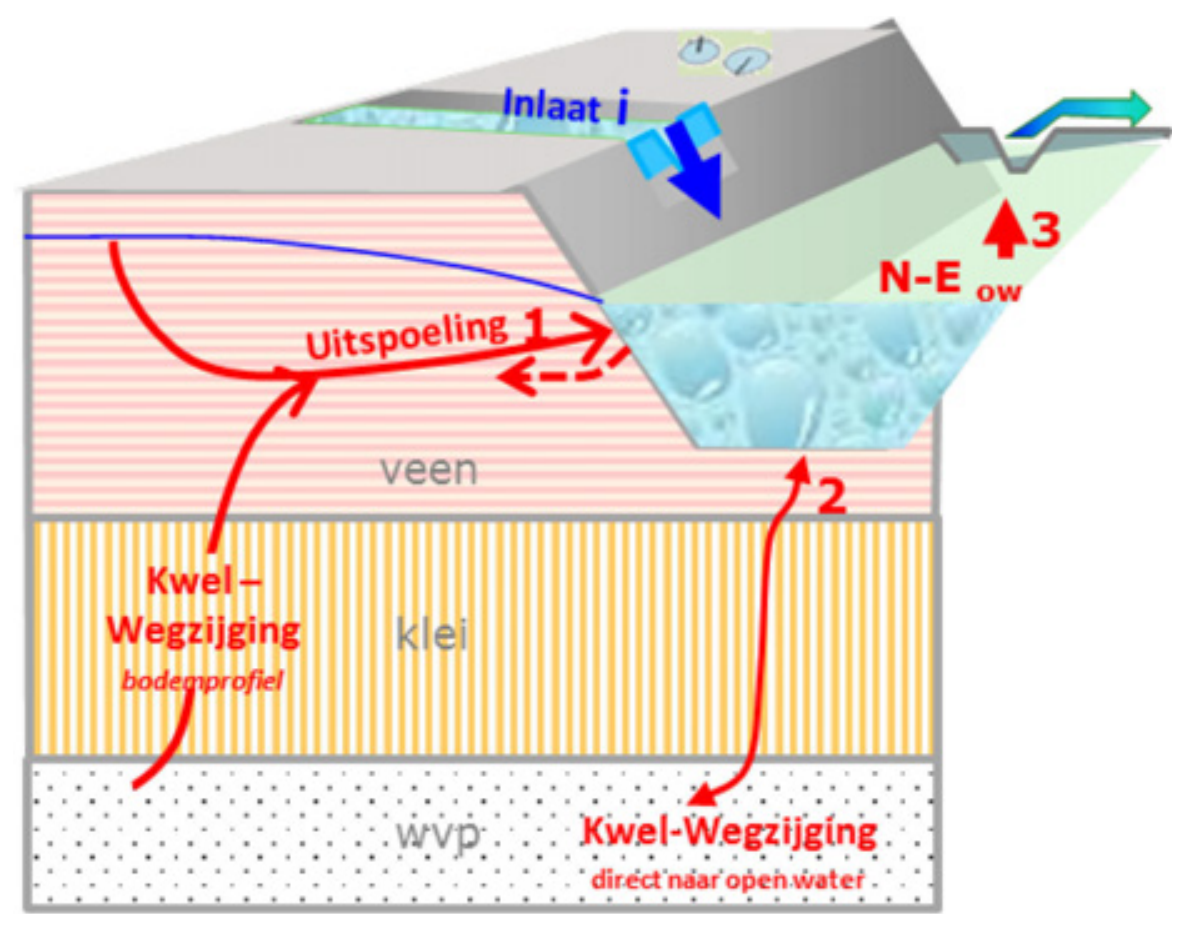

Figuur 2.10 Illustratie van de waterstromen die zijn gebruikt ter bepaling van de inlaatbehoefte voor peilhandhaving.

Om te bepalen welke nutriëntenbelasting is gemoeid met de waterinlaat, is de berekende inlaathoeveelheid vermenigvuldigd met de concentratie van het inlaatwater die volgt uit metingen van HHSK (figuur 2.11). Deze berekening is uitgevoerd op dagbasis, waarbij de concentratie op nietmeetdagen is verkregen via lineaire interpolatie tussen nabije dagen waarop wel is gemeten. In tabel 2.10 is te zien welk meetpunt is toegekend aan welke polder. Niet alle meetpunten zijn gelegen in het boezemstelsel. Zo wordt Polder Bleiswijk gevoed met water van Vaart Bleiswijk (meetpunten 5 en 54). Deze Vaart is feitelijk een verlengde van het boezemstelsel. Daarnaast krijgt de Binnenwegse Polder vooral inlaatwater vanuit Delfland (noordelijke rand) en zijn de meetpunten 211, 210 en 214 enigszins representatief voor de kwaliteit van het ingelaten water.

Tabel 2.10 Herkomst en bijbehorende waterkwaliteitsmeetpunt van het inlaatwater per polder.

\begin{tabular}{|c|c|c|c|c|}
\hline Polder & Herkomst inlaatwater & \multicolumn{3}{|c|}{ Meetpunten } \\
\hline Binnenwegse Polder & Delfland (noordrand van gebied), nauwelijks vanuit boezem & 210 & 211 & 214 \\
\hline De Wilde Veenen & Rotteboezem & 123 & & \\
\hline Eendragtspolder & Ringvaart & 7 & 60 & \\
\hline Zuidplaspolder-Zuid & Ringvaart & 7 & 60 & \\
\hline Oostpolder & Ringvaart & 24 & 36 & \\
\hline Polder EGB & Ringvaart & 38 & & \\
\hline Polder Bleiswijk & Vaart Bleiswijk & 54 & 5 & \\
\hline
\end{tabular}




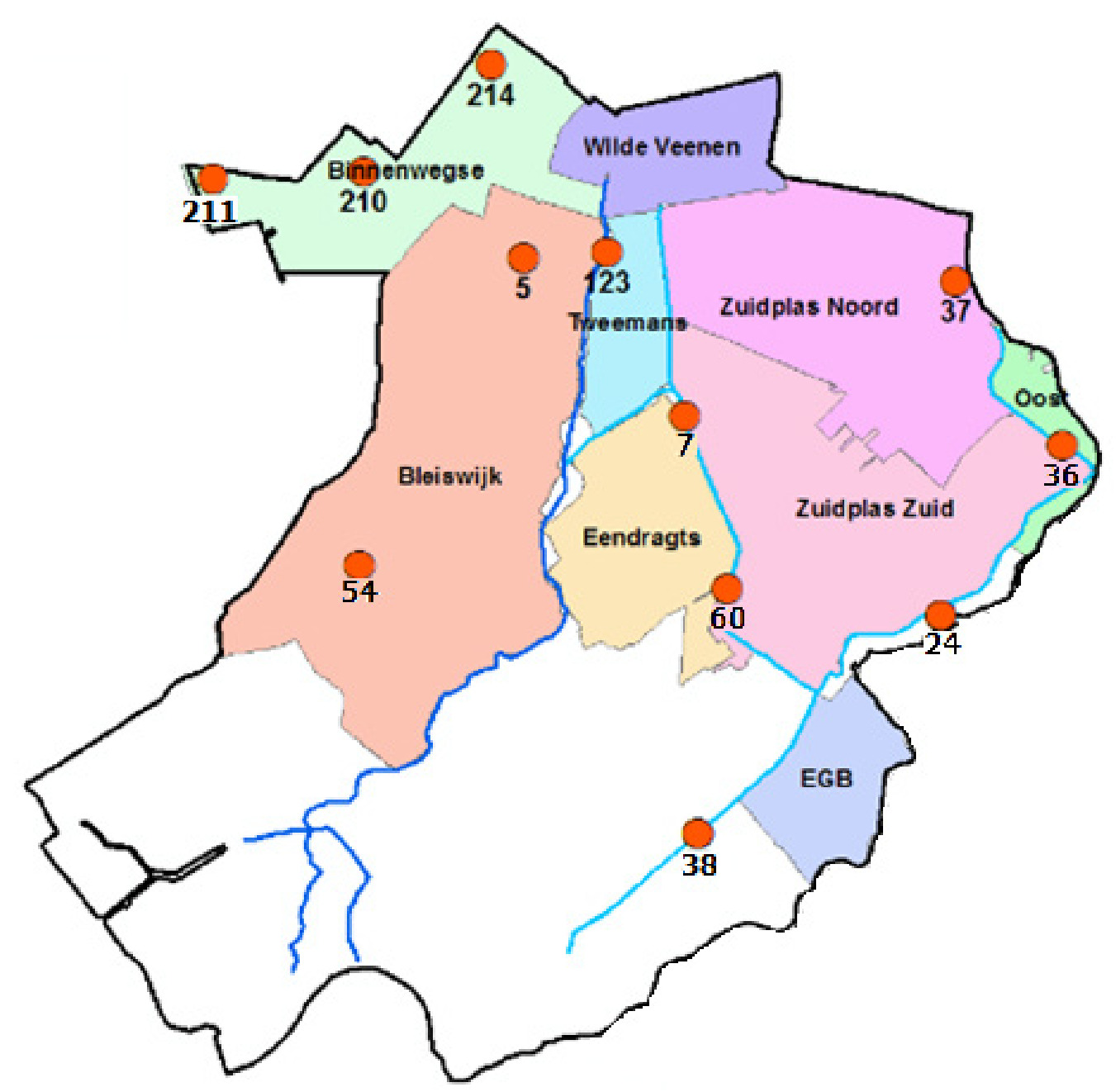

Figuur 2.11 Waterkwaliteitsmeetpunten HHSK die de kwaliteit van het inlaatwater weerspiegelen.

\section{Retentie}

Om te bepalen hoeveel nutriënten de polder verlaten (met het oog op de toetsing, zie volgende onderdeel), is het belangrijk om rekening te houden met retentie in het oppervlaktewater. Een deel van de nutriënten die in de waterlopen terechtkomen, bereikt het uitstroompunt namelijk niet, omdat ze worden vastgelegd, omgezet of verwijderd. Voorbeelden van dergelijke retentieprocessen zijn opname door waterplanten, vastlegging in de waterbodem (via sedimentatie) en gasvormige emissies naar de atmosfeer (denitrificatie).

De retentie is geschat conform de werkwijze die is gehanteerd binnen de Evaluatie Meststoffenwet 2012 (Van Boekel, 2012) en in de studie voor HHNK bij het afleiden van theoretische achtergrondconcentraties (Van Boekel, 2015). In bijlage 4 is een uitgebreide beschrijving van de methode gegeven. De belangrijkste uitganspunten voor de retentie van stikstof en fosfor zijn:

- Stikstof:

- Klei- en veenpolders:

De grootte van de retentieprocessen is voor stikstof afgeleid uit metingen (PLONS-project, www.plons.wur.nl). Op basis van de eigenschappen van de polders is de capaciteit van het oppervlaktewatersysteem bepaald om stikstof vast te leggen, uitgedrukt in gram per $\mathrm{m}^{2}$ waterbodem. De zo berekende absolute stikstofretentie is van toepassing voor alle nutriëntenbronnen in polders met voornamelijk klei of veen in de ondergrond.

- Fosfor:

- Alle polders:

Voor de fosforretentie in poldersystemen zijn dezelfde retentiefactoren aangehouden die zijn gehanteerd bij de evaluatie van de Meststoffenwet 2012. Voor de af- en uitspoeling is een vaste retentiefactor gebruikt van 0,5 en voor de andere bronnen is een vaste retentiefactor van 0,2 aangehouden. 
De retentiefactor is toegepast op het totaal aan inkomende nutriëntenvracht (zie tabel 2.4). Met de op deze manier bepaalde retentievracht kun je de netto uitgaande nutriëntenvracht berekenen (= inkomende nutriëntenvracht minus retentie).

\section{Uitgaande nutriëntenvrachten}

De berekende uitgaande nutriëntenvrachten zijn gevalideerd aan de metingen. De gemeten uitgaande vracht is bepaald door de hoeveelheid uitgeslagen water (zoals gemeten bij de gemalen) te vermenigvuldigen met de gemeten nutriëntenconcentraties van dit uitslagwater. Ter bepaling van de uitslagdebieten heeft HHSK maalstaten aangeleverd (zie tabel 2.2 voor een overzicht van de betreffende poldergemalen). Het betreft maalstaten over de periode 2005-2018. Bij de analyse van deze maalstaten bleek dat de maalstaten onvolledig zijn (tabel 2.11). De gemalen zijn voor 15 tot $78 \%$ bemeten in de onderzochte periode. De totaal uit metingen afgeleide uitgaande nutriëntenvracht geeft dan ook hoogstwaarschijnlijk een onderschatting van de werkelijke uitgaande vracht. De uit metingen afgeleide nutriëntenvracht is bepaald door de op dagbasis aangeleverde debietcijfers te vermenigvuldigen met de bij de gemalen gemeten nutriëntenconcentraties, waarbij de concentraties lineair zijn geïnterpoleerd om te komen tot concentraties op niet-meetdagen.

Tabel 2.11 Databeschikbaarheid (\%) van maalgegevens, per jaar en per gemaal.

\begin{tabular}{|c|c|c|c|c|c|c|c|c|c|}
\hline Jaar & $\begin{array}{r}\text { Lansinger } \\
\text {-land }\end{array}$ & De Graeff & $\begin{array}{r}\text { Leemhuis- } \\
\text { Stout }\end{array}$ & Zuidplas & Hitland & $\begin{array}{l}\text { Wilde } \\
\text { Veenen }\end{array}$ & De Kooi & $\begin{array}{r}\text { Binnenwegse } \\
\text {-polder }\end{array}$ & $\begin{array}{r}\text { Abraham } \\
\text { Kroes }\end{array}$ \\
\hline 2005 & 0 & 36 & 95 & 99 & 94 & 99 & 75 & 94 & 0 \\
\hline 2007 & 5 & 96 & 100 & 93 & 99 & 99 & 98 & 95 & 1 \\
\hline 2008 & 100 & 98 & 98 & 96 & 100 & 95 & 95 & 98 & 2 \\
\hline 2010 & 33 & 18 & 20 & 33 & 0 & 20 & 33 & 20 & 0 \\
\hline 2011 & 100 & 88 & 100 & 97 & 1 & 97 & 100 & 98 & 1 \\
\hline 2012 & 99 & 0 & 84 & 76 & 30 & 87 & 98 & 55 & 1 \\
\hline 2013 & 98 & 0 & 11 & 98 & 1 & 99 & 98 & 0 & 1 \\
\hline 2017 & 34 & 99 & 99 & 99 & 0 & 0 & 98 & 99 & 99 \\
\hline gemiddeld & 46 & 64 & 78 & 75 & 35 & 63 & 73 & 69 & 15 \\
\hline
\end{tabular}

\section{Toetsing van stoffenbalans}

Als een laatste stap zijn de berekende en gemeten uitgaande nutriëntenvracht met elkaar vergeleken. De resultaten van de validatie zijn weergegeven in figuur 2.12. Dit geeft een beeld van de plausibiliteit van de rekenresultaten. Uit de validatie wordt geconcludeerd dat de berekende uitgaande vrachten in dezelfde orde van grootte liggen als hetgeen uit de metingen is afgeleid. Met de kanttekening dat de uit metingen afgeleide nutriëntenvrachten waarschijnlijk een onderschatting geven vanwege de onvolledigheid van de maalstaatgegevens. 


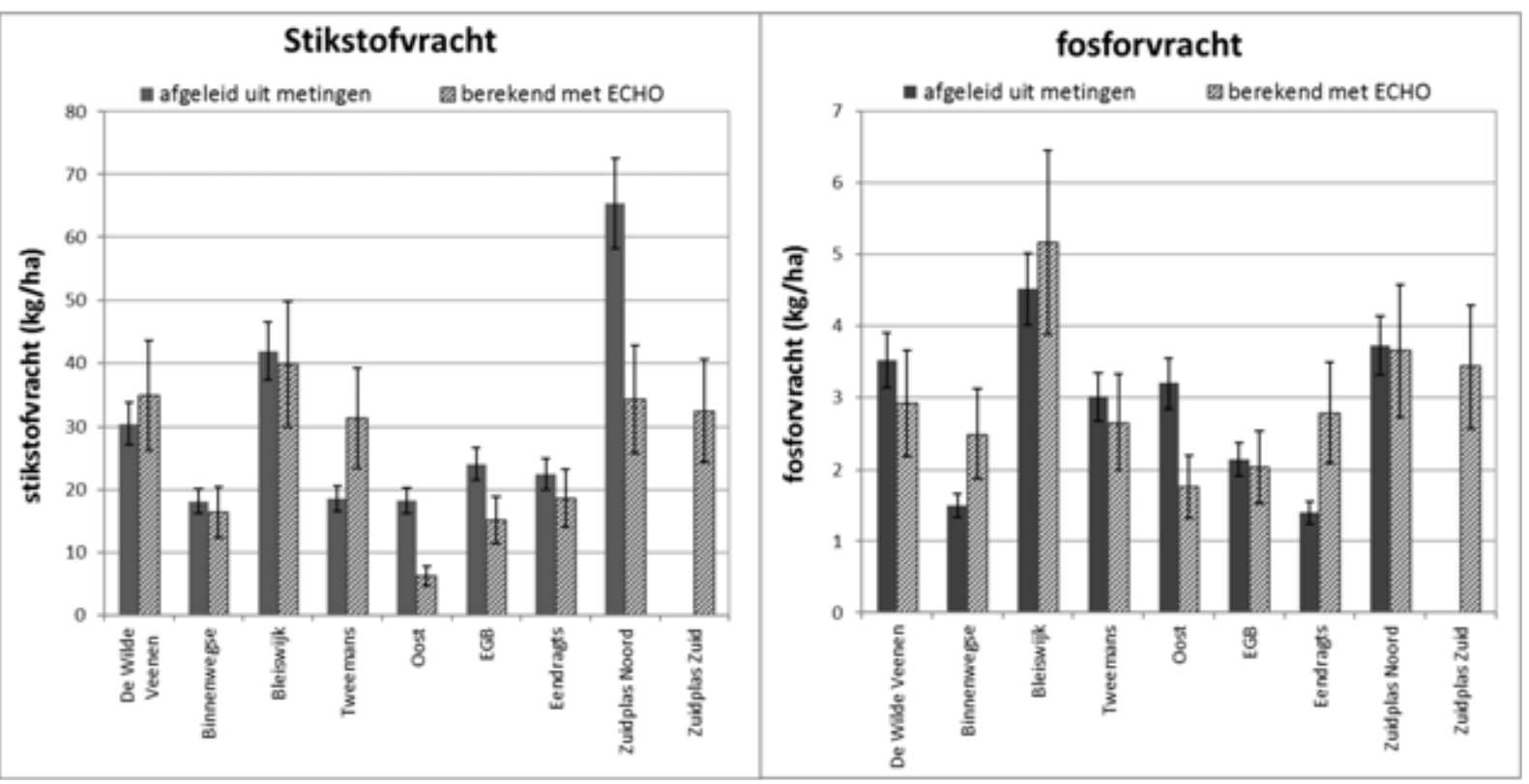

Figuur 2.12 Vergelijking berekende en uit metingen afgeleide uitgaande stikstof- en fosforvrachten.

\subsection{Herkomst nutriënten}

De herkomst van de af- en uitspoeling is verder geanalyseerd door de bronnen achter de af- en uitspoeling te berekenen (Groenendijk, 2014). De af- en uitspoeling worden hierbij uitgesplitst in de bijdrage van kwel (naar de bodem), atmosferische depositie op het land, historische mestgiften, actuele mestgiften en uitspoeling van eerder in het jaar geïnfiltreerd oppervlaktewater. Dit onderscheid is schematisch weergegeven in figuur 2.13. De af- en uitspoeling van stikstof en fosfor uit natuurgebieden worden niet verder uitgesplitst. Nadere informatie over de definitie van 'historische' en 'actuele' mestgiften is te vinden in Groenendijk (2014).

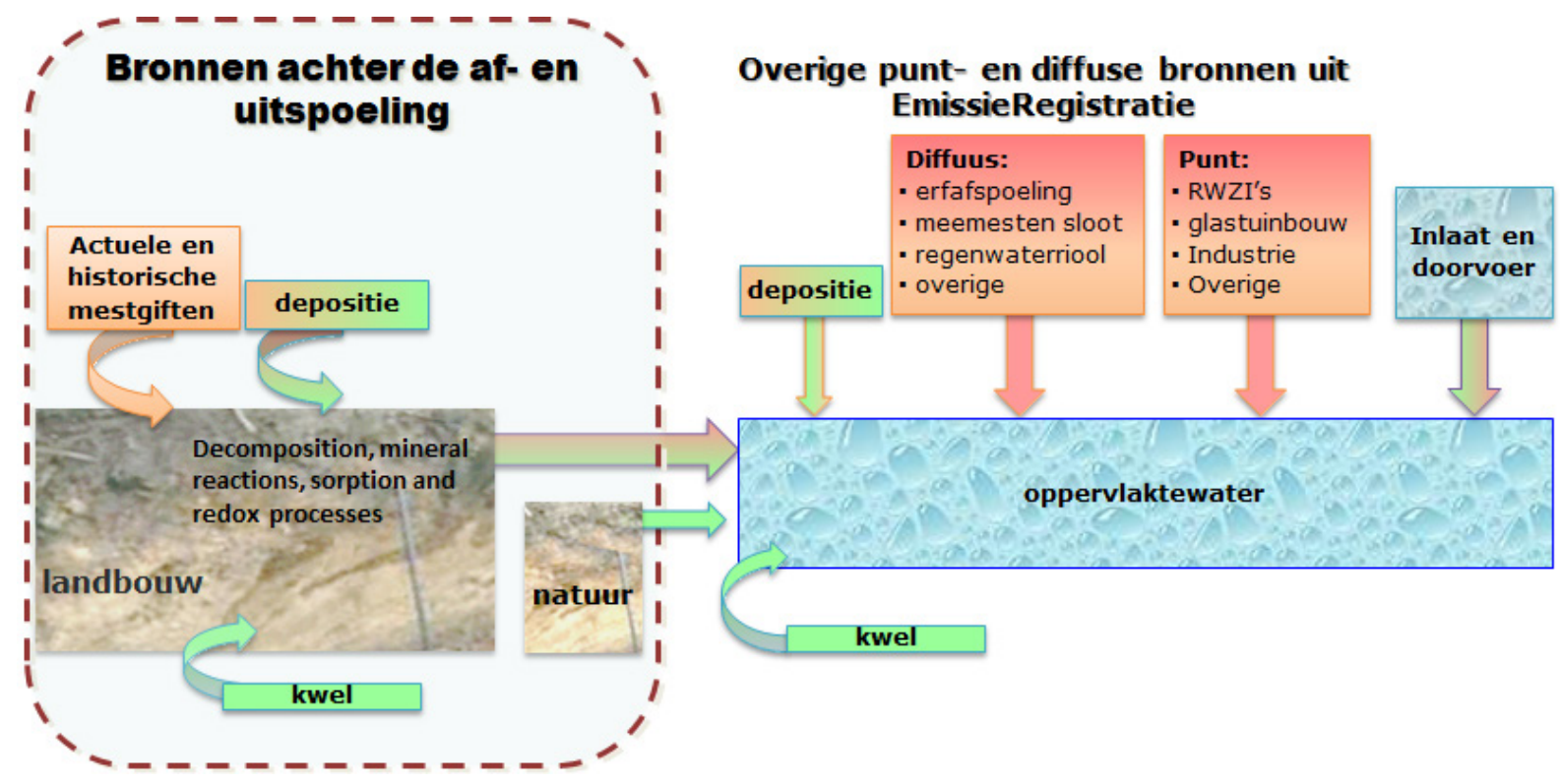

Figuur 2.13 Overzicht van de belangrijkste bronnen/emissieroutes naar het oppervlaktewater. 


\subsection{Maatregelen}

Voor een zestal typen agrarische maatregelen is berekend wat hun effect is op de af- en uitspoeling:

1. Huidige mestbeleid

2. Glastuinbouw aansluiten op riool

3. Onderwaterdrainage

4. Bodemverbetering

5. Precisiebemesting

6. Kringlooplandbouw

De maatregelen 1, 4, 5 en 6 zijn bepaald met modelberekeningen (STONE) van de af- en uitspoeling. $\mathrm{Bij}$ de effectberekening van maatregel 3 is aangesloten op eerdere studies. Effecten van glastuinbouw (aansluiting op riool) zijn gekwantificeerd met de kentallen die ook voor al gerealiseerde aansluiting op het riool zijn aangehouden. Hoofdstuk 4 beschrijft de maatregelen en hun effect in detail. 


\section{Resultaten bronnenanalyse}

\subsection{Nutriëntenbelasting per polder}

Figuur 3.1 toont de totale nutriëntenbelasting en hoe deze is opgebouwd uit de verschillende bronnen. De belasting is uitgedrukt per hectare polder. Te zien is dat de verschillen in landgebruik (zie paragraaf 2.2) tot uiting komen in de nutriëntenbelasting. Zo hebben de glastuinbouwpolders, vooral Bleiswijk, een grote belasting vanuit de glastuinbouw en krijgen de akkerbouwpolders (zoals Polder de Wilde Veenen en de Tweemanspolder) voornamelijk nutriënten via uit- en afspoelende landbouwgronden. In de Binnenwegse polder is het stedelijk gebied de belangrijkste bron van nutriënten. De nutriëntenbelasting is het grootst in polder Bleiswijk. In bijlage 7 zijn de nutriëntenbronnen in meer detail weergegeven, niet gemiddeld over 2000-2013 (zoals in figuur 3.1) maar per jaar, voor zowel stikstof (figuur B7.1) als fosfor (figuur B7.2).

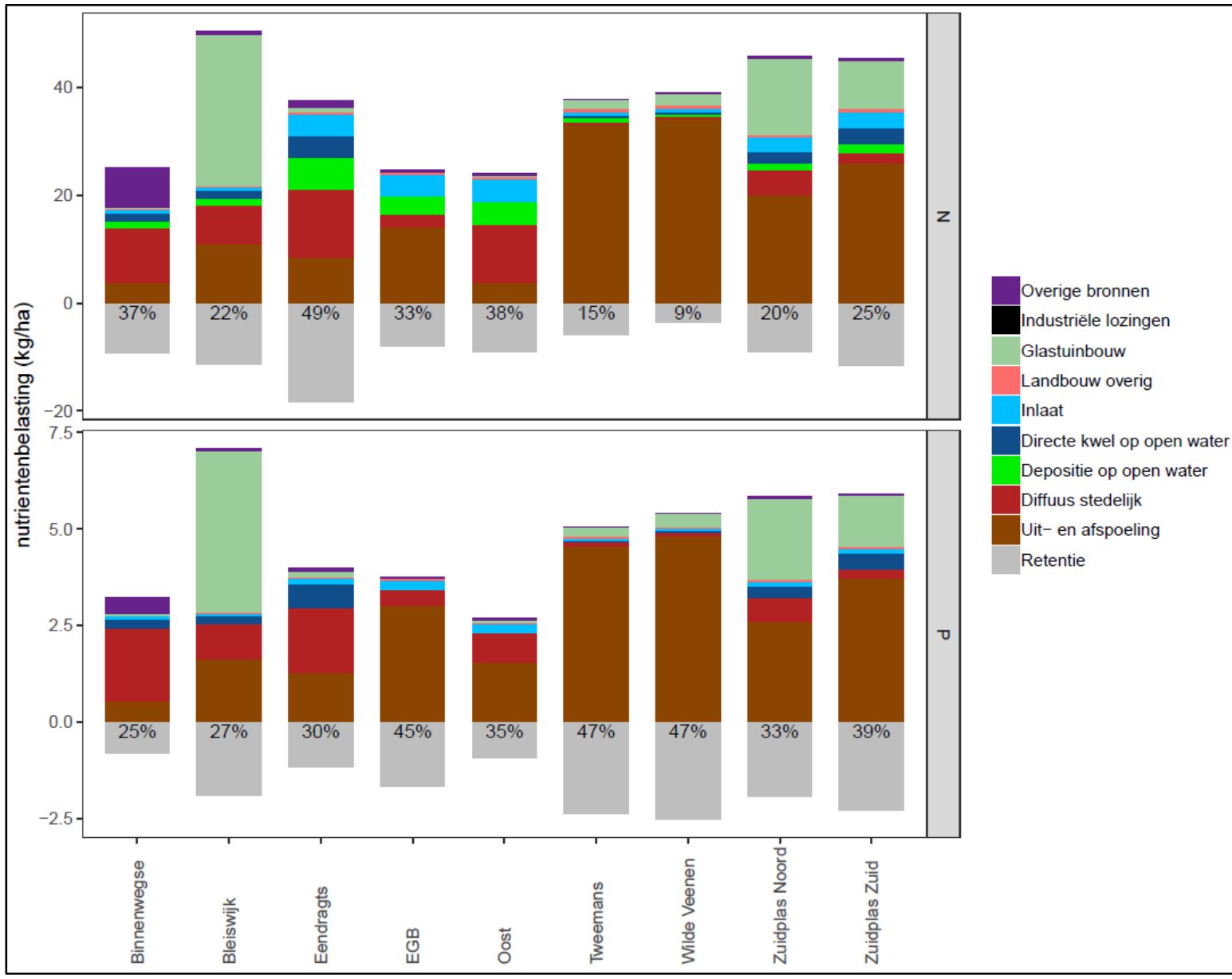

Figuur 3.1 Jaargemiddelde nutriëntenbelasting in kg per hectare polder voor de periode 2000-2013 voor stikstof (boven) en fosfor (beneden). De kleuren geven de verschillende bronnen, waarbij de nutriëntenretentie is weergegeven als een negatieve bron en het percentage aangeeft welk deel van de nutriëntenbelasting wordt vastgelegd in het oppervlaktewater door retentie.

De verschillen in de berekende retentie (figuur 3.1) houden voor N voornamelijk verband met het aandeel oppervlaktewater. Wanneer een polder meer oppervlaktewater heeft, is er meer capaciteit om nutriënten vast te leggen of te verwijderen, waardoor de N-retentie toeneemt. Zo is de N-retentie het grootst in de Eendragtspolder, omdat deze van alle polders procentueel het meeste oppervlaktewater 
heeft. Het oppervlaktewater lijkt daarmee een belangrijkere sturende factor dan de ruimtelijke variatie in afbreekbaarheid van de organische stikstof in de bodem. Voor de retentie van $\mathrm{P}$ is vooral het type bron onderscheidend in de gebruikte retentiemethodiek. Polders met voornamelijk diffuse bronnen (zoals af- en uitspoeling) hebben een retentie van bijna 50\%, terwijl polders met voornamelijk puntbronnen een lagere retentie hebben van richting de $20 \%$. Dit komt omdat nutriënten vanuit puntbronnen vaak een kortere weg afleggen richting uitstroompunt dan nutriënten vanuit diffuse bronnen, waardoor er onderweg minder tijd is voor het vastleggen van nutriënten. De retentiemethodiek houdt overigens geen rekening met seizoensverschillen in de P-retentie door vastlegging en nalevering van $\mathrm{P}$ door de waterbodem.

\section{Toetsing modelresultaten}

De modelresultaten zijn getoetst door de berekende uitgaande nutriëntenvracht (nutriëntenbelasting minus retentie) te vergelijken met de vrachten die uit metingen kan worden afgeleid. Dit vergelijk is alleen gemaakt voor jaren waarin de uitgemalen waterstromen voldoende zijn bemeten. Figuur 3.2 en 3.3 geven het resultaat voor stikstof en fosfor. Voor de Zuidplaspolder-Zuid is deze vergelijking niet gemaakt vanwege het ontbreken van (voldoende) maalstaten.

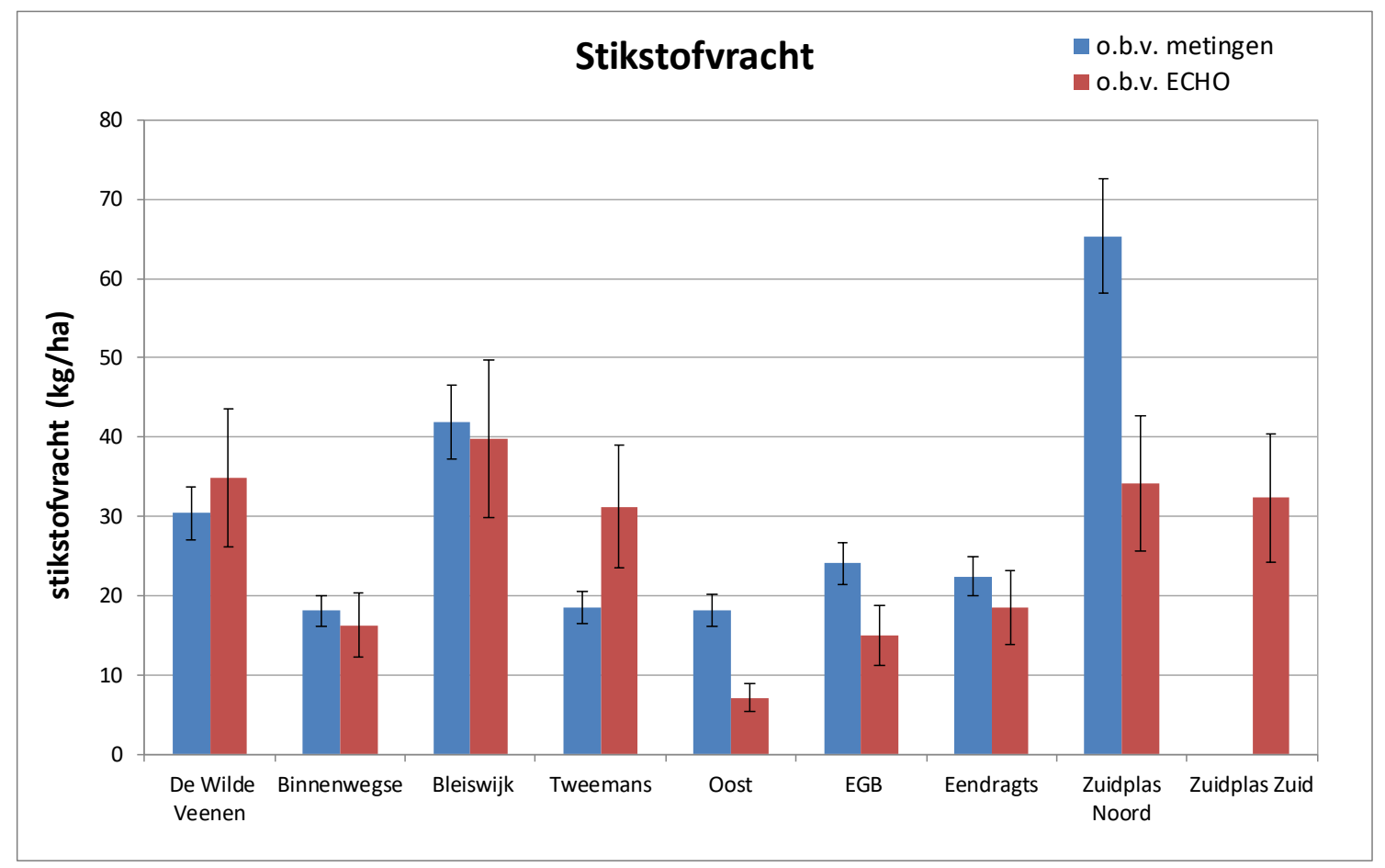

Figuur 3.2 Uitgaande jaarlijkse stikstofvracht per polder, zoals berekend in deze studie (rood) en afgeleid uit metingen (blauw). 


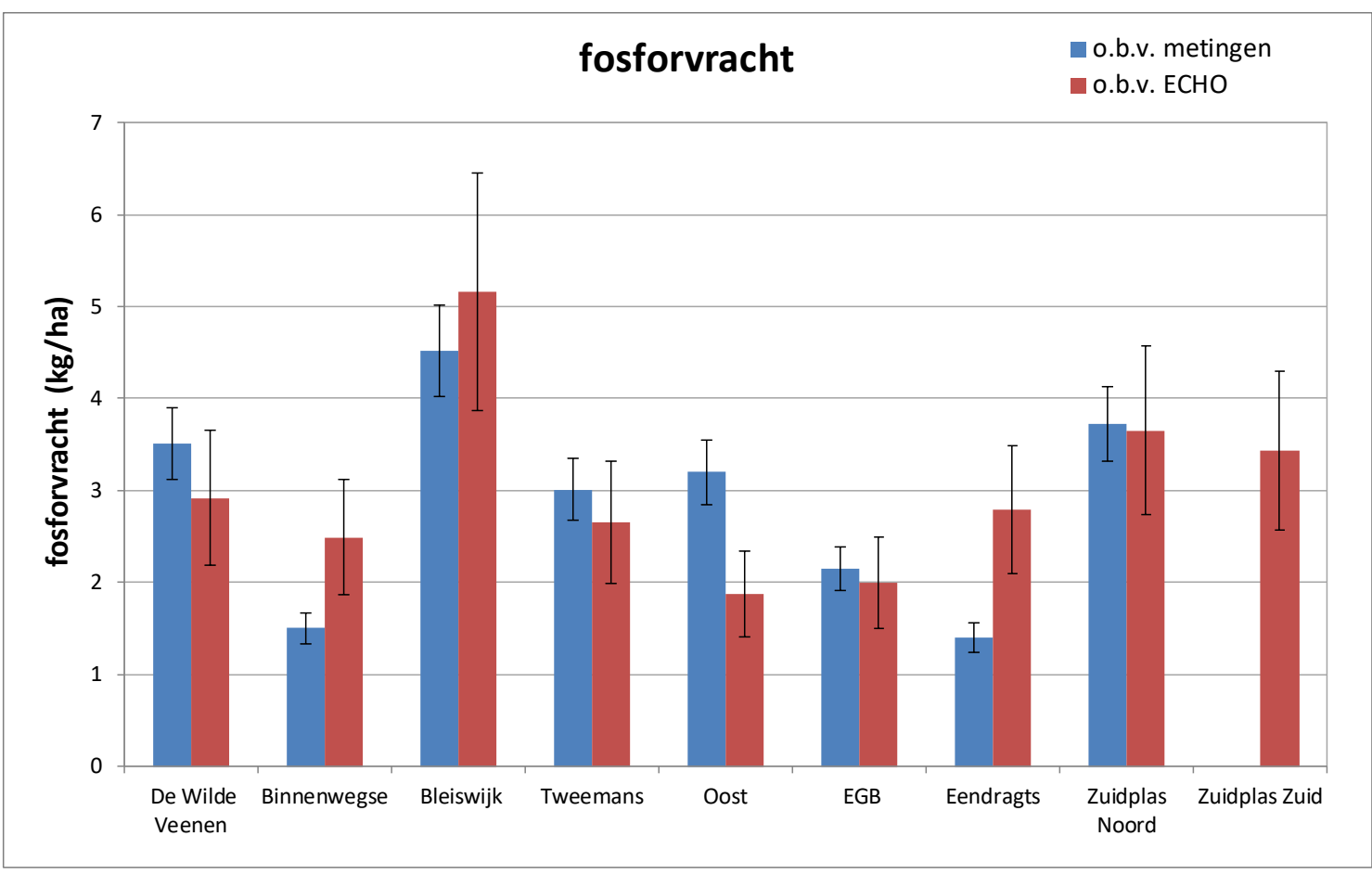

Figuur 3.3 Uitgaande jaarlijkse fosforvracht per polder, zoals berekend in deze studie (rood) en bepaald met metingen (blauw).

Te zien is dat de gemeten en berekende uitgaande vrachten voor fosfor van dezelfde orde van grootte zijn. Voor stikstof zijn de verschillen groter, vooral voor Zuidplaspolder-Noord.

In de figuren zijn ook de geschatte onzekerheden weergeven. Voor het schatten van de onzekerheidsmarge van de uit metingen afgeleide uitgaande nutriëntenvracht is gebruikgemaakt van het onderzoek dat door Deltares is uitgevoerd (Rozemeijer, 2015). Hierin is nagegaan wat het effect is van de meetfrequentie (verschil tussen tweewekelijkse metingen en maandmetingen) op de afgeleide jaarvrachten voor stikstof en fosfor. Uit de resultaten blijkt dat op basis van de maandelijkse metingen ten opzichte van de tweewekelijkse metingen de jaarvrachten voor $\mathrm{N}$-totaal een afwijking hebben van $-35,8$ tot $+19,2 \%$, de jaarvrachten voor $P$ hebben een afwijking van -24 tot $+11,9 \%$.

Voor het afleiden van de onzekerheidsmarges van de met ECHO berekende uitgaande vracht zijn de onzekerheidsmarges gebruikt die in het onderzoek van Alterra (Van Boekel et al., 2011) zijn afgeleid. Voor de berekende netto uitgaande nutriëntenbelasting (totale emissie naar water minus de retentie) is een onzekerheidsmarge van $25 \%$ voor zowel stikstof als voor fosfor aangehouden en is een resultante van alle bronnen met ieder een eigen onzekerheidsmarge.

Voorzichtigheid is geboden bij het interpreteren van de verschillen in figuur 3.2 en 3.3. Het is goed mogelijk dat de onzekerheidsmarges rond de metingen groter zijn dan aangegeven door de onzekerheden rond de geregistreerde debieten. De gebruikte maalstaten voor diverse gebieden en diverse jaren gaven geen betrouwbaar beeld geven van de debieten. Dit geldt ook voor de onzekerheden rond de berekeningen, omdat enerzijds de inlaatdebieten relatief onzeker zijn en de berekening van de retentie een grote invloed heeft. De fit tussen model en meting verbeterde overigens wel duidelijk door het bijstellen van de EmissieRegistratie schattingen voor glastuinbouw en atmosferische depositie en toevoeging van diffuse bronnen in stedelijk gebied (met name uitspoeling vanuit stedelijk groen). De bronnenanalyse zoals hier uitgevoerd, kan beter worden ondersteund als met monitoring meer en betrouwbaardere informatie wordt verzameld over de hoeveelheden die worden ingelaten en uitgemalen. 


\subsection{Af- en uitspoeling van nutriënten}

Figuur 3.4 toont per polder de berekende af- en uitspoeling van nutriënten naar het oppervlaktewater, als nadere specificatie van figuur 3.1. Het gaat om de gemiddelde af- en uitspoeling in het landelijk gebied (landbouw, natuur en stedelijk groen omdat dit is doorgerekend als natuur). De belasting is nu echter niet uitgedrukt per hectare polder (zoals in figuur 3.1), maar per hectare landelijk gebied. Te zien is dat de af- en uitspoeling per hectare landelijk gebied weinig verschillen tussen de verschillende polders, ondanks verschillen in bodemtype en in het aandeel van landbouw versus natuur. Dit correspondeert maar deels met de ruimtelijke variatie in P-concentraties in de bouwvoor alsook de P-verzadigingsgraad en de afbreekbaarheid van organische stikstof in de bodem. Dit kan samenhangen met het feit dat maar een klein deel van de $\mathrm{N}$ - en P-belasting ook daadwerkelijk afkomstig is vanuit de bouwvoor in het landelijk gebied (max. 5\% via oppervlakkige afstroming) dan wel dat de gebruikte herschikkingsprocedure geen rekening houdt met variatie in P-buffering en $\mathrm{N}$-nalevering vanuit de bodem.

Alleen de wegzijgingsgebieden (Polder EGB en Polder Oost) vertonen een 'afwijkend' beeld en hebben de laagste af- en uitspoeling, vooral voor N. Dit komt doordat in wegzijgingsgebieden een deel van het overtollige water/nutriënten wordt afgevoerd naar het grondwater in plaats van naar het oppervlaktewater, resulterend in een kleinere belasting naar het oppervlaktewater in vergelijking met kwelgebieden. Deze kwel en infiltratie overrulen daarmee eventuele verliezen die kunnen optreden door een hogere $\mathrm{N}$-beschikbaarheid in de bovenste laag van de bodem. Desalniettemin is de P-af- en P-uitspoeling in de wegzijgingsgebieden ongeveer even groot als in de kwelgebieden. Dit komt voor een deel door de grote P-nalevering vanuit de diepere veenbodem (zie paragraaf 3.3), aangezien Polder EGB en de Oostpolder beide veenpolders zijn.

De resultaten van de herschikkingsprocedure zijn terug te vinden in bijlage 5 . Deze resultaten laten zien welke Swap-Animo-rekenplots ten grondslag liggen aan de af- en uitspoelingsberekeningen en wat hun eigenschappen zijn. Weergegeven zijn de gebruikte indeling van de polders naar landgebruik, bodemtype en hydrologie en de mate van herschikking die nodig was om de binnen een polder aanwezige combinaties van landgebruik, bodem en hydrologie toe te kennen aan Swap-Animorekenplots. In bijlage 6 zijn de af- en uitspoelingsresultaten te zien in meer detail. Deze resultaten zijn nu niet gemiddeld over de periode 2000-2013, maar zijn weergegeven per jaar (figuur B6.1). Hierin is te zien dat de af- en uitspoeling variëren met ongeveer een factor 2 tussen de verschillende jaren. Zo zijn de af- en uitspoeling significant lager in een droog jaar zoals 2003.

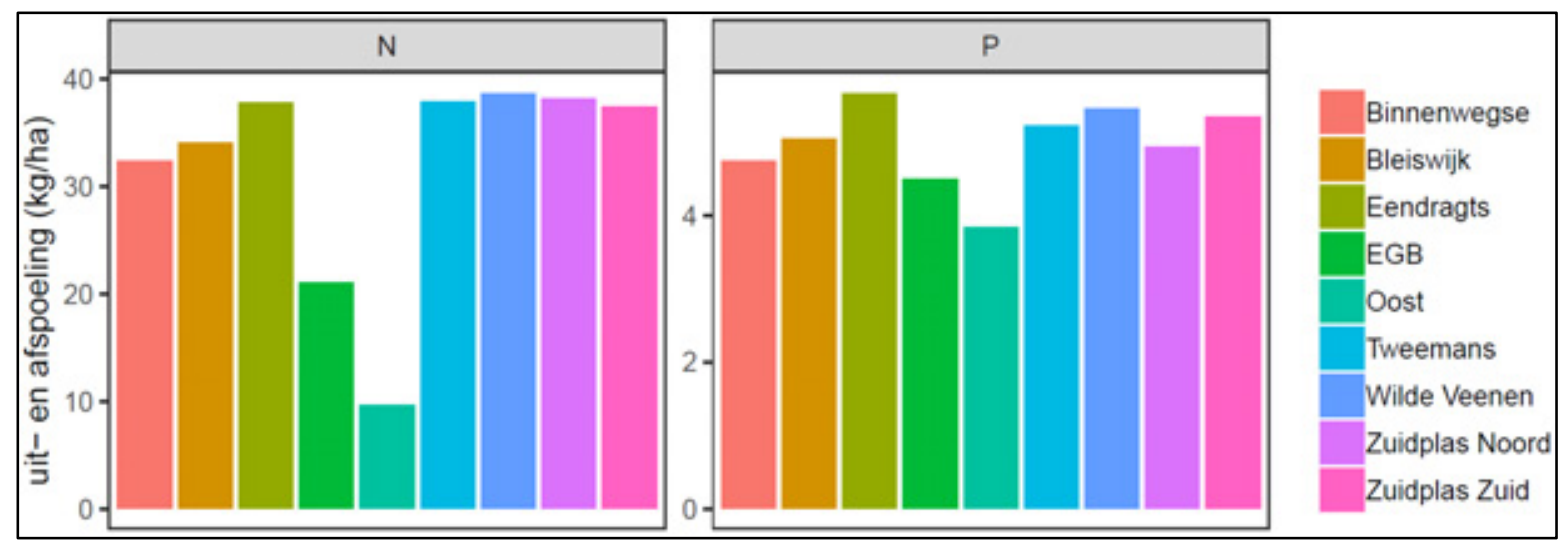

Figuur 3.4 Jaargemiddelde af- en uitspoeling vanuit landelijk gebied in de periode 2000-2013, voor stikstof (links) en fosfor (rechts), uitgedrukt in $\mathrm{kg}$ per hectare landelijk gebied. 


\subsection{Herkomst nutriënten}

In dit onderzoek is de recente belasting (2000-2013) van het oppervlaktewater met stikstof en fosfor in beeld gebracht en de herkomst hiervan afgeleid. Voor waterbeheerders is het vervolgens interessant om te weten welk deel van de belasting door bronmaatregelen te sturen zijn. In een notitie die is opgesteld voor de Nutriëntenwerkgroep Rijn-West (Schipper, 2012) zijn de nutriëntenbronnen ingedeeld naar beïnvloedbaarheid (direct of op korte/lange termijn en niet beïnvloedbaar (tabel 3.1)).

Tabel 3.1 Indeling nutriëntenbronnen naar beïnvloedbaarheid.

\begin{tabular}{|c|c|c|c|c|}
\hline Categorie & $\begin{array}{l}\text { Bronnen / } \\
\text { emissieroutes }\end{array}$ & $\begin{array}{l}\text { Effect } \\
\text { bronreductie }\end{array}$ & Type emissie & Bronnen \\
\hline \multirow{5}{*}{ 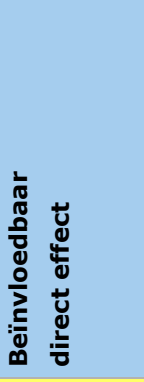 } & Rwzi's & Direct effect & Effluentlozing & $\begin{array}{l}\text { Huishoudelijk afvalwater, lozingen } \\
\text { op riool }\end{array}$ \\
\hline & Industriële lozingen & Direct effect & Effluentlozing & Industrie \\
\hline & $\begin{array}{l}\text { Overige agrarische } \\
\text { emissies }\end{array}$ & Direct effect & Diffuse lozingen & $\begin{array}{l}\text { Meemesten sloten, erfafspoeling, } \\
\text { glastuinbouw }\end{array}$ \\
\hline & Waterinlaat & Direct effect & $\begin{array}{l}\text { Waterinlaat vanuit boezem, } \\
\text { Rijkswateren e.a. }\end{array}$ & Bronnen buiten het gebied \\
\hline & Overige bronnen & Direct effect & Punt en diffuus & $\begin{array}{l}\text { Ongerioleerde lozingen, } \\
\text { overstorten }\end{array}$ \\
\hline \multirow{2}{*}{ 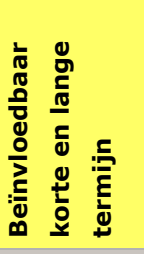 } & Actuele bemesting & $\begin{array}{l}\text { Korte en lange } \\
\text { termijn } \\
1)\end{array}$ & $\begin{array}{l}\text { Afspoeling en uitspoeling } \\
\text { (sloten, greppels, } \\
\text { buisdrainage) }\end{array}$ & Huidige grondgebonden landbouw \\
\hline & $\begin{array}{l}\text { Nalevering } \\
\text { bodemcomplex } \\
\text { landbouwgronden } 2 \text { ) }\end{array}$ & Lange termijn & $\begin{array}{l}\text { Uitspoeling (sloten, } \\
\text { greppels, buisdrainage) }\end{array}$ & $\begin{array}{l}\text { Geogeen, historische bemesting, } \\
\text { kwel en depositie }\end{array}$ \\
\hline \multirow{4}{*}{ 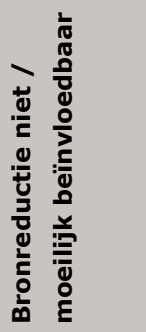 } & $\begin{array}{l}\text { Atmosferische depositie } \\
\text { open water en bodem }\end{array}$ & Niet haalbaar & $\begin{array}{l}\text { Depositie open water en } \\
\text { natuur/landbouw bodems }\end{array}$ & $\begin{array}{l}\text { Luchtemissies landbouw, verkeer, } \\
\text { industrie, energie, buitenland }\end{array}$ \\
\hline & Kwel waterlopen & Niet haalbaar $\left.{ }^{4}\right)$ & $\begin{array}{l}\text { Kwel direct naar waterlopen } \\
\text { en naar bodem }\end{array}$ & $\begin{array}{l}\text { Geogeen, mogelijk verhoogd door } \\
\text { antropogene invloed }\end{array}$ \\
\hline & $\begin{array}{l}\text { Infiltratie } \\
\text { oppervlaktewater }\end{array}$ & Niet haalbaar & $\begin{array}{l}\text { Diffuse infiltratie lokaal } \\
\text { oppervlaktewater }\end{array}$ & Lokale en bovenstroomse bronnen \\
\hline & Natuurgronden & & Diffuse af- en uitspoeling & $\begin{array}{l}\text { Geogeen, door antropogene invloed } \\
\text { verhoogde depositie }\end{array}$ \\
\hline
\end{tabular}

1) Zowel voor $\mathrm{N}$ als $\mathrm{P}$ kan bronreductie voor een deel snel effect hebben door afname afspoeling en uitspoeling vanuit hotpots en korte stromingspatronen. Voor fosfor kan het uiteindelijke effect decennia duren, voor stikstof is deze termijn in het algemeen veel korter. Binnen het huidige mestbeleid heeft sturen op $\mathrm{P}$ op korte termijn geen effect mits maatregelen direct ingrijpen op de belangrijkste verliesroutes.

2) Nalevering door verwering, oplossen metaal(hydr)oxides, oxidatie, historische bemesting, historische kwel en historische depositie.

3) Bronreductie niet haalbaar, maar atmosferische depositie op landbouwgronden zou meegerekend kunnen worden in het bepalen van de mestgiften. In voorgenomen landelijk mestbeleid wordt atmosferische depositie niet meegenomen.

4) Significante bronreductie niet haalbaar, omdat de bron gerelateerd is aan functie van het gebied dan wel de drooglegging en daardoor op te vatten als onomkeerbare hydromorfologische ingreep.

Met deze uitsplitsing van bronnen kan onderscheid worden gemaakt tussen antropogene bronnen en overige bronnen die beleidsmatig als natuurlijke of seminatuurlijk kunnen worden beschouwd. Hierbij wordt opgemerkt dat de keuzes voor het wel of niet beschouwen als natuurlijk of seminatuurlijk een beleidsmatige keuze is. De berekende uitsplitsing van de herkomst van de nutriëntenbelasting is weergegeven in figuur 3.5 en in tabel 3.2 (stikstof) en 3.3 (fosfor). 


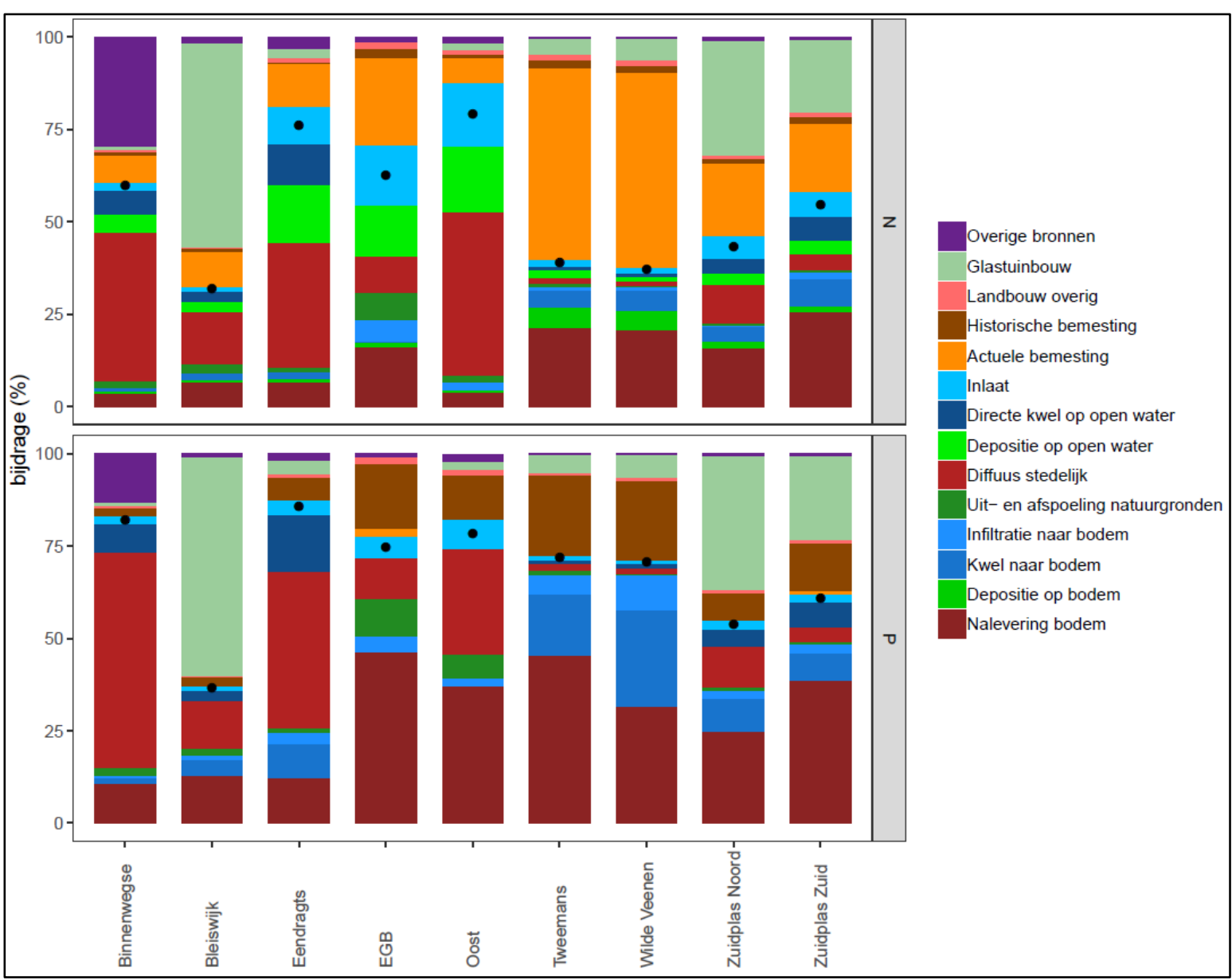

Figuur 3.5 Herkomst nutriënten in de periode 2000-2013 voor stikstof (boven) en fosfor (beneden). De zwarte punten geven het percentage aan achtergrondbelasting. De bronnen onder de punt zijn 'natuurlijk', de bronnen erboven zijn van humane oorsprong. Aangenomen is dat de inlaat voor de helft van natuurlijke oorsprong is en voor dit de helft van humane komaf.

Uit de resultaten blijkt dat de herkomstverdeling per gebied vrij sterk verschilt. Dit is niet vreemd gezien de heterogeniteit in Schieland wat betreft landgebruik (grasland, akkerbouw, glastuinbouw, stedelijk), bodem (klei of veen) en hydrologie (kwel of wegzijging). Zo hebben de veenpolders zoals EGB vaak een grotere term 'nalevering uit de bodem' dan de kleipolders, vooral voor P. Tegelijkertijd zijn de actuele P-concentraties in de bovengrond aan de lage kant en treedt in veenpolders meer retentie op in de bodem. Optredende P-verliezen naar het oppervlaktewater gaan daarbij overigens vaak samen met hoge verliezen van aluminium en ijzer, die samen zorgen voor (extra) retentie van $P$ in het oppervlaktewater dan wel slootbodem.

Voor P is het aandeel 'nalevering bodem' vaak groter dan het aandeel 'bemesting'. Bemesting bestaat vooral uit 'historische bemesting' omdat in het verleden de gebruiksnormen voor P hoger waren.

Voor $\mathrm{N}$ zien we een ander beeld: het aandeel 'nalevering uit de bodem' is op minerale gronden vaak kleiner dan het aandeel uit 'bemesting' en de bemesting bestaat vooral uit 'actuele bemesting'. Dit komt doordat $\mathrm{N}$ minder goed kan binden aan de bodem dan $\mathrm{P}$ en daardoor sneller uit- en afspoelt en meer wordt beïnvloed door actuele bemesting. Veengronden zijn daarbij de uitzondering, omdat daar de natuurlijke $\mathrm{N}$-nalevering van de bodem (afhankelijk van de kwaliteit van het veen en de ontwatering) vele malen hoger kan zijn dan de actuele mestgift. Bij de meer stedelijke polders zoals de Binnenwegse Polder is de bijdrage vanuit 'diffuus stedelijk' het grootst.

Ook is te zien dat de glastuinbouw een groot effect heeft in de polders met glastuinbouw (Bleiswijk, Zuidplaspolder-Zuid en -Noord). Deze glastuinbouwpolders hebben tevens het meeste handelingsperspectief, vooral voor $\mathrm{P}$, omdat de achtergrondbelasting hier procentueel gezien het kleinst is (zie zwarte stippen in figuur 3.5) en er dus de meeste winst is te behalen met het terugdringen van 
humane nutriëntenbronnen (vooral glastuinbouw). Voor $\mathrm{N}$ is er tevens veel handelingsperspectief in de typische akkerbouwpolders (Tweemanspolder en Polder Wilde Veenen), gezien de grote bijdrage van de (actuele) bemesting aan de totale $\mathrm{N}$-belasting op het oppervlaktewater.

Tabel 3.2 Herkomst stikstofbelasting oppervlaktewater (jaargemiddelde 2000 tot en met 2013) in $\mathrm{kg} / \mathrm{ha}$. Bronnen met een aandeel groter dan $10 \%$ zijn gemarkeerd weergegeven.

\begin{tabular}{|c|c|c|c|c|c|c|c|c|c|}
\hline DEELGEBIED & $\begin{array}{l}\frac{5}{0} \\
\frac{5}{0} \\
j \\
0 \\
0 \\
0 \\
0 \\
0 \\
0\end{array}$ & 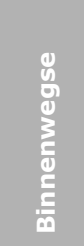 & 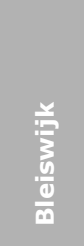 & 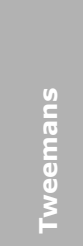 & $\begin{array}{l}\text { 艹 } \\
\text { 。 }\end{array}$ & 芫 & 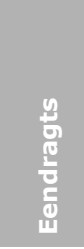 & 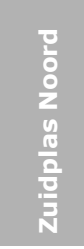 & 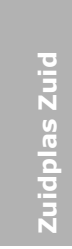 \\
\hline OPPERVLAK (HA) & 728 & 1424 & 3767 & 469 & 254 & 606 & 1096 & 2150 & 2425 \\
\hline actuele bemesting & 20.7 & 1.8 & 4.8 & 19.6 & 1.6 & 5.8 & 4.3 & 9.0 & 8.3 \\
\hline historische bemesting & 0.7 & 0.2 & 0.4 & 0.8 & 0.2 & 0.6 & 0.2 & 0.5 & 0.9 \\
\hline nalevering bodem & 8.1 & 0.9 & 3.3 & 8.1 & 1.0 & 4.0 & 2.5 & 7.3 & 11.6 \\
\hline atmosferische depositie & 2.1 & 0.2 & 0.4 & 2.0 & 0.1 & 0.3 & 0.4 & 0.8 & 0.6 \\
\hline kwel & 2.1 & 0.2 & 0.8 & 1.8 & 0.0 & 0.0 & 0.7 & 1.8 & 3.3 \\
\hline infiltratie & 0.4 & 0.0 & 0.1 & 0.3 & 0.5 & 1.5 & 0.1 & 0.1 & 0.9 \\
\hline uit- en afspoeling natuurgronden & 0.1 & 0.4 & 1.1 & 0.3 & 0.4 & 1.8 & 0.4 & 0.4 & 0.3 \\
\hline diffuus stedelijk gebied & 0.4 & 10.1 & 7.2 & 0.6 & 2.3 & 2.0 & 12.7 & 4.7 & 1.9 \\
\hline overige agrarisch emissies & 0.6 & 0.2 & 0.2 & 0.6 & 0.3 & 0.5 & 0.4 & 0.4 & 0.5 \\
\hline glastuinbouw & 2.2 & 0.2 & 27.9 & 1.6 & 0.4 & 0.0 & 0.9 & 14.3 & 8.9 \\
\hline atmosferische depositie & 0.5 & 1.2 & 1.3 & 0.9 & 4.3 & 3.4 & 5.9 & 1.3 & 1.7 \\
\hline industriële lozingen & 0.0 & 0.0 & 0.0 & 0.0 & 0.0 & 0.0 & 0.0 & 0.0 & 0.0 \\
\hline overige emissies & 0.1 & 7.4 & 0.7 & 0.1 & 0.4 & 0.3 & 1.1 & 0.4 & 0.3 \\
\hline inlaat & 0.6 & 0.5 & 0.7 & 0.6 & 4.2 & 4.0 & 3.9 & 2.8 & 3.1 \\
\hline directe kwel open water & 0.4 & 1.6 & 1.4 & 0.4 & 0.0 & 0.0 & 4.1 & 1.9 & 2.8 \\
\hline Totaal IN & 39.1 & 25.0 & 50.5 & 37.8 & 15.8 & 24.1 & 37.5 & 45.8 & 45.3 \\
\hline
\end{tabular}

Tabel 3.3 Herkomst fosforbelasting oppervlaktewater (jaargemiddelde 2000 tot en met 2013) in $\mathrm{kg} / \mathrm{ha}$. Bronnen met een aandeel groter dan $10 \%$ zijn gemarkeerd weergegeven.

\begin{tabular}{|c|c|c|c|c|c|c|c|c|c|}
\hline DEELGEBIED & $\frac{5}{3}$ & 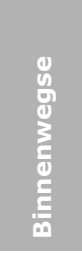 & $\frac{\frac{y}{3}}{\frac{5}{c}}$ & 늘 & 항 & $\frac{m}{\mathrm{C}}$ & $\frac{\text { o }}{5}$ & $\begin{array}{l}\frac{0}{5} \\
8 \\
\frac{0}{2} \\
\frac{4}{10} \\
\frac{10}{2} \\
\frac{7}{3}\end{array}$ & $\begin{array}{l}\text { 을 } \\
\text { N } \\
\frac{2}{10} \\
\frac{0}{2} \\
\frac{0}{3}\end{array}$ \\
\hline actuele bemesting & 0.0 & 0.0 & 0.0 & 0.0 & 0.0 & 0.1 & 0.0 & 0.0 & 0.0 \\
\hline historische bemesting & 1.2 & 0.1 & 0.2 & 1.1 & 0.3 & 0.7 & 0.2 & 0.4 & 0.8 \\
\hline nalevering bodem & 1.7 & 0.3 & 0.9 & 2.3 & 1.0 & 1.7 & 0.5 & 1.4 & 2.3 \\
\hline atmosferische depositie & 0.0 & 0.0 & 0.0 & 0.0 & 0.0 & 0.0 & 0.0 & 0.0 & 0.0 \\
\hline diffuus stedelijk gebied & 0.1 & 1.9 & 0.9 & 0.1 & 0.8 & 0.4 & 1.7 & 0.6 & 0.2 \\
\hline overige agrarisch emissies & 0.0 & 0.0 & 0.0 & 0.0 & 0.0 & 0.1 & 0.0 & 0.0 & 0.1 \\
\hline glastuinbouw & 0.3 & 0.0 & 4.2 & 0.2 & 0.1 & 0.0 & 0.1 & 2.1 & 1.3 \\
\hline atmosferische depositie & 0 & 0 & 0 & 0 & 0.0 & 0.0 & 0 & 0 & 0 \\
\hline industriële lozingen & 0.0 & 0.0 & 0.0 & 0.0 & 0.0 & 0.0 & 0.0 & 0.0 & 0.0 \\
\hline overige emissies & 0.0 & 0.4 & 0.1 & 0.0 & 0.1 & 0.0 & 0.1 & 0.0 & 0.0 \\
\hline inlaat & 0.1 & 0.1 & 0.1 & 0.1 & 0.2 & 0.2 & 0.2 & 0.1 & 0.1 \\
\hline directe kwel open water & 0.1 & 0.2 & 0.2 & 0.1 & 0.0 & 0.0 & 0.6 & 0.3 & 0.4 \\
\hline Totaal IN & 5.4 & 3.2 & 7.1 & 5.1 & 2.7 & 3.7 & 4.0 & 5.8 & 5.9 \\
\hline
\end{tabular}




\subsection{Reflectie op de af- en uitspoeling}

De berekende af- en uitspoeling hebben niet de ruimtelijk gedetailleerde informatie van de bouwvoor benut die gegenereerd is met de Eurofins data. Wat bij de vergelijking opvalt, is dat de met Eurofins data berekende beschikbaarheid van $\mathrm{P}$ in de bouwvoor (zie figuur 2.7-2.9) grotere verschillen laat zien dan de met de ECHO berekende uitspoeling. Het is echter de vraag of die variatie in P-beschikbaarheid ook tot een variatie in P-uitspoeling zou leiden. Want dat zou alleen gelden voor de transportroutes over maaiveld of zeer ondiep onder maaiveld. Dieper dan $25 \mathrm{~cm}$ heeft Eurofins geen data terwijl een groot deel van de bindings- en transportprocessen die de uitspoeling beïnvloeden juist dieper dan $25 \mathrm{~cm}$ plaatsvinden. Verder geldt dat de rekenplots van STONE per bemalingsgebied worden uitgemiddeld en dat de rekeneenheden van STONE (de Swap-Animo-bodemkolommen) niet dezelfde ruimtelijke detailinformatie hebben over de bodemeigenschappen die de $\mathrm{N}$ - en P-verliezen van oppervlakkige afstroming en ondiepe uitspoeling beïnvloeden.

Het is onduidelijk of het meenemen van deze informatie verschillen geeft in de per bemalingsgebied berekende af- en uitspoeling. De studie van Kros et al. (2017) laat zien dat een individueel perceel met een afwijkende P-toestand een grote invloed kan hebben op de P-belasting in polders, maar in deze modelstudie is uitgegaan van een modelprofiel dat niet dieper gaat dan de wortelzone, waardoor processen dieper in het profiel niet worden meegenomen. Eerdere berekeningen in het veenweidegebied (Schipper, 2016; Van den Akker, 2019; Stowa Deltafact) laten zien dat de belangrijkste P-verliezen optreden vanuit de diepere bodemlagen, waardoor de eventuele over- of onderschatting van de toplaag de conclusies van deze studie niet wezenlijk veranderen. Er bleek uit de Swap-Animo van STONE-berekeningen dat de P-toestand van de diepere bodemlagen in veengebieden weinig bepaald worden door de P-toestand van de bouwvoor, vooral ook als sprake is van kwel. Voor stikstof is er wel een sterkere koppeling tussen de $\mathrm{N}$-nalevering zoals gemeten in de bouwvoor en de $\mathrm{N}$-nalevering in de diepere bodemlagen. Niet zozeer voor nitraatuitspoeling (in natte veengebieden wordt dit gereduceerd), maar wel voor de uitspoeling van organische stikstof. Het is niet duidelijk of de berekende uitspoeling van organische stikstof verandert als het model geënt wordt op de $\mathrm{N}$-nalevering die voor de bouwvoor is berekend.

Het waterkwaliteitsbeheer kan beter worden ondersteund als met monitoring meer en betrouwbaardere informatie wordt verzameld over de hoeveelheden die worden ingelaten en uitgemalen. Daarmee kan ook een bijdrage worden geleverd aan mogelijkheden om het energieverbruik te verminderen, want alles wat onnodig wordt ingelaten, moet ook weer worden uitgemalen. 


\section{Maatregelen}

\subsection{Algemene beschouwing over maatregelen}

Er zijn honderden maatregelen bekend om de belasting vanuit landbouwgronden te verlagen, zowel vanuit de BOOT-lijst als de DAW-factsheets. Deze maatregelen kunnen gegroepeerd worden in vier type maatregelen die achtereenvolgens ingrijpen op het nutriëntenoverschot (bron), de efficiëntie van bemesting (maatregelen bodemkwaliteit), de verliesroutes dan wel de retentie in het ontvangende waterlichaam (figuur 4.1). Van de in deze studie doorgerekende maatregelen grijpen maatregel 2 'Glastuinbouw aansluiten op riool' en maatregel 3 'Onderwaterdrainage' aan op de verliesroutes, is maatregel 6 'Kringlooplandbouw' een bron-maatregel en grijpen maatregelen 4 'Bodemverbetering' en maatregel 5 'Precisiebemesting' aan op de efficiëntie van bemesting dan wel het bodemoverschot. Maatregel 1 'Huidige bemesting' bevat een combinatie van verschillende typen maatregelen.

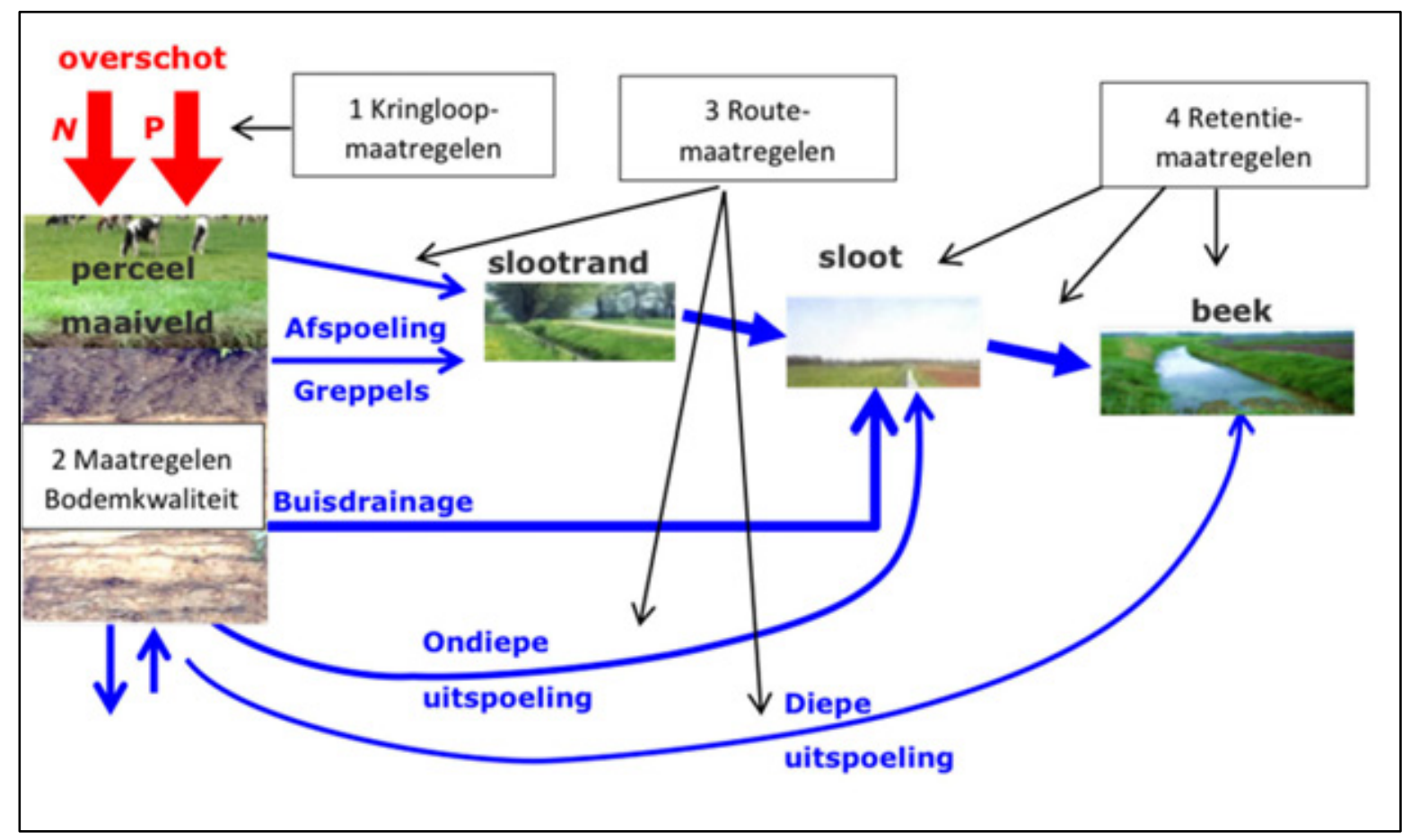

Figuur 4.1 Indeling van maatregelen voor het verlagen van de nutriëntenbelasting van het oppervlaktewater naar aangrijpingspunt: kringloop, bodem, route en retentie (Rozemeijer, 2016).

Het mestbeleid in Nederland was tot 2016 vooral gericht op verlaging van de aanvoer van mest naar de bodem, dat wil zeggen een reductie van het overschot. Dit gebeurde via gewasspecifieke gebruiksnormen voor werkzame N, P-normen afhankelijk van de bodemtoestand, en gebruiksvoorschriften wanneer mest wel of niet toegediend mag worden. In het laatste $\left(6^{\mathrm{e}}\right)$ Nitraatactieprogramma wordt echter meer dan voorheen aandacht besteed aan maatregelen die ingrijpen op de transportroutes richting het oppervlaktewater (routemaatregelen). Uit eerdere studies blijkt dat deze aanvullende acties essentieel zijn om de doelen van de KRW te bereiken (Grinsven \& Bleeker, 2017). Anno 2018 krijgt dat vooral vorm via het bovenwettelijke spoor binnen het Deltaplan Agrarisch Waterbeheer (DAW). Het grootste deel van deze maatregelen focust op kringloopmaatregelen en bodemkwaliteit.

De BOOT-lijst vermeldt groene en rijpe maatregelen zonder onderscheid te maken. Voor de maatregelen op deze lijst geldt overwegend dat een positief effect op de waterkwaliteit wordt verwacht op basis van logisch redeneren, soms ondersteund met modelberekeningen. Slechts van een 
klein aantal maatregelen zijn de effecten werkelijk onderzocht in veldonderzoek. Daarbij komt dat de daadwerkelijke effectiviteit afhangt van de manier waarop de maatregelen worden ingezet. Enkele voorbeelden hiervan zijn:

- Maatregelen die zorgen voor betere bemesting werken alleen als ook daadwerkelijk de hoogte van de gift wordt aangepast aan de hogere werking.

- Maatregelen voor een goed slootkantbeheer / bufferstroken zijn alleen effectief bij een goede uitvoering.

- Maatregelen die pleiten voor meer organische stof werken alleen als er minder dan $2 \%$ in de bodem aanwezig is, en als ze ingepast zijn binnen een goed doordacht bouwplan (met bodembeheer). Zonder deze inbedding kan een verhoging van organische stof via aanvoer van reststromen (die deels buiten de mestboekhouding vallen) zelfs zorgen voor negatieve effecten op de waterkwaliteit.

De meeste maatregelen zijn namelijk alleen effectief in specifieke bodems of bouwplannen of gelden alleen voor $\mathrm{N}$ of voor $\mathrm{P}$. Of bij het combineren van maatregelen versterking of uitdoving van effecten verwacht mag worden, is niet bekend. De link tussen maatregelen en effecten op de ecologische waterkwaliteit is daarbij vaak indirect, en vaak alleen op langere termijn zichtbaar. Op basis van expertkennis is geconcludeerd dat met combinaties van de geselecteerde maatregelen, boven op de maatregelen van bestaand beleid, een substantiële daling van de stikstof- en fosforconcentraties in het oppervlaktewater kan worden gerealiseerd (Groenendijk, 2016; Rozemeijer, 2016). De toepassing, effectiviteit, de kosteneffectiviteit en termijn waarop effecten op de waterkwaliteit zichtbaar zijn, zijn echter sterk afhankelijk van regionale omstandigheden.

De Commissie Deskundigen Meststoffenwet (Velthof, 2018) heeft recentelijk een eerste selectie gemaakt van effectieve maatregelen:

- gewasbeheer: rijenbemesting bij maïs en groentegewassen, voorjaarstoediening van mest op kleigrond in plaats van najaarstoediening, uitbreiding van het areaal vanggewas, geen mest toedienen op gescheurd grasland, afvoer van gewasresten en hergebruik van slootbagger;

- bodembeheer: uitmijnen van bodemfosfaat in landbouwgronden, de teelt van maïs in stroken uitgefreesd in grasland en minimale grondbewerking;

- hydrologische maatregelen: beperken van oppervlakkige afspoeling en verbeterde drainage;

- technische maatregelen: het inrichten van reactieve barrières in en op de bodem van een landbouwperceel en fosforverwijdering uit het oppervlaktewater (waterzuivering);

- ruimtelijke maatregelen: aanpassen van het bouwplan, beperking van beweiding, teelten uit de grond, grasbufferstroken en het saneren van hotspots van af- en uitspoeling.

De mogelijke reductie in $\mathrm{N}$ - en P-belasting die te realiseren is via bodemverbeterende maatregelen of maatregelen die ingrijpen op de efficiëntie van bemesting, varieert tussen klei, veen en zandgronden, waarbij de effecten voor stikstof groter zijn dan die voor fosfaat. Of deze reductie ook daadwerkelijk gerealiseerd kan worden, hangt in sterke mate samen met de implementatiegraad van de maatregelen. Een effectieve aanpak stuurt daarom via goed afgestemd bodem- én waterbeheer op een hoge benutting en retentie, waarbij rekening wordt gehouden met de lokale geohydrologie. De grootste effecten worden verwacht van maatregelen die ingrijpen op ondiepe af- en uitspoelingsroutes, in het bijzonder voor fosfaat. De studie van Groenendijk (2016) laat zien dat binnen een periode van 10 jaar de belasting met maximaal 10 à $15 \%$ kan worden verlaagd voor $\mathrm{P}$ en met maximaal $35 \%$ voor $\mathrm{N}$.

\subsection{Huidige mestbeleid}

De effecten van het mestbeleid op de af- en uitspoeling naar het oppervlaktewater zijn afgeleid op basis van bestaande berekeningen met STONE (Groenendijk, 2015) die zijn uitgevoerd in het kader van de exante-evaluatie KRW (Van Gaalen, 2016). Dit betreft modelberekeningen waarin alleen de veranderingen in gebruiksnormen en werkingscoëfficiënten zijn meegenomen. Andere ontwikkelingen (o.a. groei melkveestapel) en/of beleid (o.a. Wet verantwoorde Groei Melkveehouderij) zijn hierin niet meegenomen. De reden hiervoor is dat voor de inschatting van de effecten van het $5^{\mathrm{e}}$ Actieprogramma is uitgegaan van mestberekeningen met MAMBO die eind 2014 zijn uitgevoerd, waarbij gebruikgemaakt is van cijfers uit 2013. Op dat moment waren nog geen cijfers bekend over de groei van de melkveehouderij. Met het beschikbaar komen van de Evaluatie Meststoffenwet 2016 in 2017 zullen voor 
het eerst cijfers beschikbaar komen waarin de groei van de veestapel is doorgerekend naar de mestintensiteiten en toepassing van mesttypen.

Het voorgenomen mestbeleid grijpt voornamelijk aan op de nutriëntenbelasting van het oppervlaktewater via af- en uitspoeling vanuit landbouwgronden. De belasting vanuit andere bronnen verandert niet, hoewel verwacht kan worden dat het voorgenomen mestbeleid ook enige invloed heeft op de emissies vanuit overige agrarische bronnen (meemesten sloten, erfafspoeling, glastuinbouw). Het effect van het voorgenomen mestbeleid op de bijdrage van deze bronnen is niet bekend en derhalve niet meegenomen.

De effecten van het huidige mestbeleid op de af- en uitspoeling voor het zichtjaar 2027-2030 zijn berekend door een link te leggen tussen de rekeneenheden die bij de herschikking voor Schieland zijn geselecteerd en de rekeneenheden waarmee met de landelijke modelstudie het effect van het huidige mestbeleid ( $5^{\mathrm{e}} \mathrm{NAP}$ ) is berekend.

\subsection{Glastuinbouw aansluiten op riool}

Vanaf 2015 zijn alle glastuinbouwbedrijven in Schieland aangesloten op het riool. Hierdoor neemt de belasting naar het oppervlaktewater af en dragen alleen nog lekverliezen vanuit de glastuinbouw naar de bodem bij aan de oppervlaktewaterbelasting.

In de beschouwde referentieperiode (2010-2013) zijn veel glastuinbouwbedrijven nog niet aangesloten op het riool, vooral de bedrijven in Polder Bleiswijk (zie tabel 2.8). Deze maatregel berekent het effect als in de periode 2010-2013 alle bedrijven volledig zijn aangesloten op het riool, zoals nu feitelijk al het geval is.

\subsection{Onderwaterdrainage}

Onderwaterdrainage (OWD) is een vorm van drainage waarbij de drains 10 tot $20 \mathrm{~cm}$ onder het slootpeil worden aangelegd. De grondwaterstand zakt daardoor in de zomerperiode minder ver uit. Het veen blijft natter en wordt minder snel afgebroken (geoxideerd). Omdat de drains alle wateruitwisseling tussen sloot en veenbodem versnellen, kan bij piekbuien water tijdelijk in de veenbodem worden opgeslagen en daaruit weer snel worden afgevoerd (Hendriks en Van den Akker, 2012). Meer achtergrondinformatie over de werking en effecten van onderwaterdrainage is te vinden in een van de Deltafacts van Deltaproof. ${ }^{4}$

Verondersteld wordt dat onderwaterdrainage een aantal gunstige effecten heeft:

- Door de hogere grondwaterstand in het perceel blijft de grond vochtig en daarmee zuurstofloos, waardoor afbraak van veen door oxidatie met ongeveer de helft wordt afgeremd.

- Door onderwaterdrainage vermindert de fluctuatie van de grondwaterstand, waardoor de kans op verdroging of vernatting afneemt met betere gewasopbrengsten en nutriëntenbenutting als gevolg.

- Zowel door de verandering van transportroutes in de bodem als door de afname van veenafbraak (waardoor minder $\mathrm{N}$ en $\mathrm{P}$ onder de wortelzone wordt gemineraliseerd) als door de verbeterde nutriëntenbenutting, vermindert de uitspoeling van zowel $\mathrm{N}$ als $\mathrm{P}$ naar het oppervlaktewater.

- Door onderwaterdrainage kan de snelheid van de bodemdaling mogelijk met de helft worden vertraagd. De dikte van een kleidek heeft hier wel invloed op.

- In natte perioden zijn de percelen beter te berijden.

\footnotetext{
4 http://deltaproof.stowa.nl/Publicaties/deltafact/Onderwaterdrains.aspx
} 
Uit de diverse studies naar onderwaterdrainage volgt dat dit vooral succesvol is onder de volgende omstandigheden:

- De bodem bestaat uit veen en bevat geen dik kleidek.

- De drooglegging (zomerpeil) bedraagt maximaal $60 \mathrm{~cm}$ en minimaal $30 \mathrm{~cm}$ t.o.v. maaiveld. Uit oogpunt van nutriëntenuitspoeling lijkt $45 \mathrm{~cm}$ een gunstige drooglegging. Te grote drooglegging kan namelijk leiden tot meer sulfaatuitspoeling, doordat de drains de oxidatie van pyriet dan stimuleren i.p.v. remmen. Bij te geringe drooglegging neemt de kans op uitspoeling van meststoffen toe, vooral voor stikstof.

- Er is geen sterke kwel.

Voor het onderhavige onderzoek is het effect van onderwaterdrainage ingeschat op basis van de modelstudie met SWAP-ANIMO naar de effecten van grootschalige toepassing van onderwaterdrainage in peilvak 9 in polder Groot-Wilnis Vinkeveen (Hendrik, 2014). In dit onderzoek is een verlaging van de nutriëntenbelasting door onderwaterdrainage op de lange termijn (40 jaar) berekend van $17 \%$ voor $\mathrm{N}$ en van $23 \%$ voor $\mathrm{P}$.

Voor de rekenplots die voor de polders van Schieland zijn geselecteerd, is nagegaan welke hiervan voldoen aan de bovengenoemde criteria (veen zonder kleidek, droogleggen 40-60 cm -mv, geen sterke kwel). De arealen die voldoen aan de toepasbaarheidscriteria zijn aangegeven in tabel 4.1. In deze tabel is ook de afname van de uitspoeling weergegeven. Het effect, uitgedrukt in het percentage van de huidige af- en uitspoeling, is vooral groot in de Oostpolder, omdat hier het meeste areaal beschikbaar is waar OWD succesvol kan worden toegepast. Hierbij moet worden bedacht dat juist in de Oostpolder voor stikstof een relatief lage af- en uitspoeling is berekend.

Tabel 4.1 Effect Onderwaterdrainage (OWD) op de nutriëntenbelasting van het oppervlaktewater.

\begin{tabular}{|c|c|c|c|c|}
\hline Polder & $\begin{array}{c}\text { Totaal } \\
\text { areaal (ha) }\end{array}$ & Geschikt areaal OWD (ha) & \multicolumn{2}{|c|}{ Afname af-en uitspoeling door OWD } \\
\hline Bleiswijk & 727 & 29 & $-0.2 \%$ & $-0.6 \%$ \\
\hline Oost & 85 & 85 & $-15.0 \%$ & $-20.2 \%$ \\
\hline Zuidplas-zuid & 1276 & 417 & $-2.6 \%$ & $-7.0 \%$ \\
\hline
\end{tabular}

\subsection{Bodemverbetering}

Voor een goede gewasopbrengst en bijbehorende goede benutting van nutriënten is het belangrijk dat de bodem van voldoende kwaliteit is. Dat betekent dat de bodem bij voorkeur voldoende organisch materiaal bevat en niet verdicht is, zodat er een goede beschikbaarheid is van voedingsstoffen, water en zuurstof. De maatregel 'bodemverbetering' berekent het gecombineerde effect van de volgende maatregelen:

- Tegengaan bodemverdichting: verdichte grond loswoelen of diepploegen, en geen grondbewerkingen meer uitvoeren in ongunstige (natte) perioden (op minerale gronden).

- Organisch stofgehalte (in schrale gronden met minder dan $2 \%$ organische stof) verhogen.

- Gewassen en rassen kiezen die dieper wortelen.

Deze maatregel is landelijk doorgerekend met STONE (Groenendijk, 2016). De in die studie berekende maatregel heeft betrekking op zand, zavel en kleigronden met risico op ondergrondverdichting (zie figuur 4.2). Veengebieden zijn buiten beschouwing gelaten gezien hun beperkte risico op bodemverdichting. De maatregel is dus vooral van toepassing op de akkerbouwpolders in het studiegebied: de Wilde Veenen, Zuidplas-Noord en de Tweemanspolder. Deze polders lopen door intensieve bodembewerking en ruggenteelten een verhoogd risico op $\mathrm{N}$ - en $\mathrm{P}$-afspoeling en de bodemkwaliteit staat onder druk. 
Het met het STONE-model berekende effect op de af- en uitspoeling van nutriënten is geschaald met een factor voor de mate van het risico voor ondergrondverdichting. Bij het berekenen van het effect is ervan uitgegaan dat de gewasopname stijgt door het nemen van maatregelen die de bodemstructuur verbeteren: $10 \%$ hogere $\mathrm{N}$ - en P-opname akker- en tuinbouw gewassen, en $5 \%$ hogere $\mathrm{N}$ - en P-opname grasland en snijmais. Daarnaast is aangenomen dat de waterhuishouding verbetert door het tegengaan van verdichting: door de betere doorlatendheid van de bodem neemt de kans op oppervlakkige afstroom af en verbetert de capillaire nalevering van grondwater met minder kans op droogteschade tot gevolg.

Meer details over de gekozen modelaanpak bij het doorrekenen van deze maatregel is te vinden in Groenendijk (2016). De effecten van bodemverbetering zijn berekend door een link te leggen tussen de rekeneenheden die bij de herschikking voor Schieland zijn geselecteerd en de rekeneenheden waarmee met de landelijke modelstudie het effect van bodemverbetering op de af- en uitspoeling is berekend.

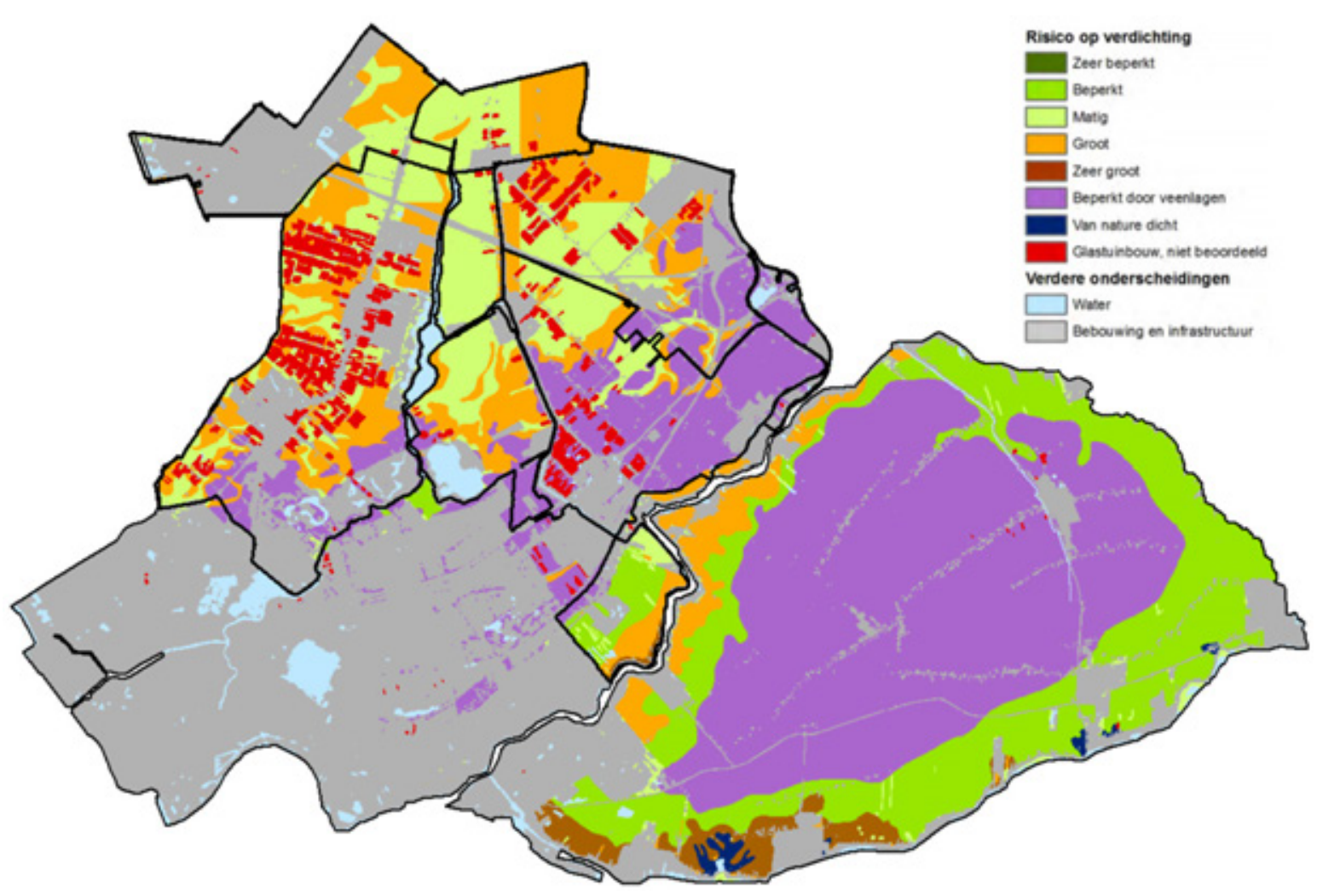

Figuur 4.2 Gevoeligheid voor ondergrondverdichting in het beheergebied van HHSK. Het gaat om een uitsnede van een landelijke bodemverdichtingskaart die is gemaakt voor het PRISMA-project 'Gevoeligheid voor ondergrondverdichting in het landelijk gebied' (Van den Akker, 2012).

\subsection{Precisiebemesting}

De af- en uitspoeling van nutriënten naar het oppervlaktewater kan worden verminderd door het beter timen en plaatsen van de mestgift, zodat het gewas de nutriënten in de mest beter benut. Ook het telen van een vanggewas na de oogst zorgt voor een betere nutriëntenbenutting. De maatregel 'precisiebemesting' berekent het gecombineerde effect van de volgende maatregelen:

- Stel voorjaarstoediening van dierlijke mest met 4 weken uit t.o.v. wat nu is toegestaan.

- Geef iets minder N-kunstmest, want de werkzaamheid van dierlijke mest is door latere toediening iets groter.

- Pas op zuidelijke zandgronden rijenbemesting toe bij maisteelt.

- Teel een vanggewas na (vroeg rijpe) snijmais op zand- en lössgrond.

- Teel een vanggewas op $40 \%$ van het areaal aan akker- en tuinbouwgewassen (granen en helft consumptieaardappelen). 
Voor ons studiegebied zijn alleen de bovenste twee maatregelen en de laatste maatregel van toepassing. De bovenste twee maatregelen gelden voor zowel bouwland als grasland, terwijl de laatste maatregel alleen betrekking heeft op de akkerbouwpolders in Schieland. Bij het met het STONE-model berekende effect van 'precisiebemesting' is aangenomen dat de N-kunstmest gift daalt met $5 \%$ voor zangronden en met $2 \%$ voor kleigronden. Daarnaast is aangenomen dat het vanggewas na akker- en tuinbouwgewassen $90 \mathrm{~kg} \mathrm{~N} \mathrm{ha-1}$ opneemt vanaf medio augustus; dit vereist overigens wel vakmanschap, omdat dit in de praktijk niet vaak gerealiseerd wordt. Omdat de maatregel geldt voor $40 \%$ van het akker- en tuinbouwareaal komt dit neer op gemiddeld $36 \mathrm{~kg} \mathrm{~N} \mathrm{ha}^{-1}$. Meer details over de gekozen modelaanpak bij het doorrekenen van deze maatregel is te vinden in Groenendijk (2016).

\subsection{Kringloopwijzer-plus}

Onder 'kringloopwijzer-plus' wordt verstaan het nemen van maatregelen om de kringloop van stikstof op het bedrijf zodanig te verbeteren dat de stikstofbodemoverschotten afnemen. Daling van het stikstofbodemoverschot is in de praktijk vaak rendabel gebleken voor melkveehouders (Verloop, 2017), maar kan ook haalbaar zijn voor diverse akkerbouwgewasrotaties, met name als daar binnen de rotatie effectieve vanggewassen worden ingezet. Zinvol is ook om de mest slim te verdelen over de percelen van een bedrijf: percelen met een hoge benutting zouden meer mest moeten krijgen dan percelen met een lage benutting. Indirecte parameters voor een hoge bodemvruchtbaarheid zijn de fosfaatbuffer-index als het $\mathrm{N}$-leverend vermogen.

Met uitgekiend mineralenmanagement kunnen melkveebedrijven het stikstofbodemoverschot veelal verlagen. Gebruikmakend van historische meetgegevens in het westelijke veenweidegebied laat een analyse van kringloopcijfers zien dat de best presterende kringloopboeren gemiddeld $11 \mathrm{~kg} \mathrm{P}^{-1}$ minder fosfaatoverschot hebben en $40-72 \mathrm{~kg} \mathrm{ha}^{-1}$ minder stikstofoverschot. Het vakmanschap van de ondernemer is hierbij cruciaal; door te sturen op de 4xR-strategie (de mest in de juiste vorm, de juiste hoeveelheid, de juiste locatie en het juiste tijdstip) kan efficiënt gestuurd worden op een hoge benutting van nutriënten en lage verliezen naar het watersysteem. Goede kennis van de natuurlijke bodemvruchtbaarheid en kennis van de belangrijkste verliesroutes is hierbij erg belangrijk.

Heel concreet betekent dat bijvoorbeeld:

- Het toepassen van minder uitspoelingsgevoelige minerale $\mathrm{N}$-meststoffen in het voorjaar.

- Het verdiepen van de beworteling van grasland.

- Het gebruik van vanggewassen en groenbemesters, waarbij de bemesting van het volggewas wordt aangepast op de vrijkomende $\mathrm{N}$ uit de ondergewerkte gewasresten.

- Het beperken van het scheuren van grasland en het aanpassen van de bemesting na het scheuren.

- Het beter inzetten van mest op die percelen waar de hoogste opbrengstpotentie kan worden gerealiseerd, rekening houdend met de natuurlijke levering van $\mathrm{N}$ en $\mathrm{P}$ van percelen.

- Het actief sturen op lagere P-concentraties in de bodemoplossing bij gelijkblijvende of hogere P-buffering.

- Het beperken van stikstof-kunstmest in het najaar, in afhankelijkheid van de afbreekbaarheid van de organische stikstof in de bodem (zie paragraaf 3.4).

In samenwerking met betrokken waterschappen, provincies, LTO en agrarische collectieven heeft het NMI in 2017 bijvoorbeeld een kringlooplandbouwpakket ontwikkeld waarmee agrarisch ondernemers beloond worden op basis van hun kringloopefficiëntie. Het kringlooppakket is een combinatie van een beperkt aantal vaste maatregelen en een vrije keuze aan flexibel te kiezen maatregelen. De maatregelen kunnen met een bepaalde intensiteit worden uitgevoerd en zijn van toepassing op het gehele bedrijf. Maatregelen betreffen onder andere:

- Mestvrije zones langs de sloot;

- Het op orde brengen van de bodem pH;

- Het beperkt scheuren van grasland;

- Sturen op de timing van de N-bemesting met kunstmest;

- Het eiwitarm en structuurrijk voeren en sturen op het ureumgehalte van de melk;

- Het gebruik van vanggewassen na vroeg geoogste maisrassen. 
Gericht op vermindering van de N-uitspoeling naar water is de daling van het N-bodemoverschot maatgevend. Op basis van berekeningen die in een eerdere studie is uitgevoerd (Groenendijk, 2016), is per rekeneenheid van Swap-Animo berekend hoeveel de af- en uitspoeling van $\mathrm{N}$ afneemt bij daling van het bodemoverschot met $1 \mathrm{~kg} / \mathrm{ha}$. Door een link te leggen tussen de rekeneenheden die bij de herschikking voor Schieland zijn geselecteerd en de rekeneenheden van de landelijke studie is berekend hoeveel de $\mathrm{N}$-af- en $\mathrm{N}$-uitspoeling afneemt. Hierbij is aangenomen dat het voor de melkveehouders mogelijk is om met 'Kringloopwijzer+'-maatregelen het $\mathrm{N}$-bodemoverschot te verlagen met $60 \mathrm{~kg} \mathrm{~N} / \mathrm{ha}^{-1}$. Gegeven de huidige bemestingspraktijk, bodemtoestand en de mestmarkt (met negatieve prijs), is het waarschijnlijk dat de P-voorraden op grasland verder zullen afnemen. Wel gaat deze ontwikkeling langzaam. Op bouwland mag nog relatief veel P worden aangevoerd, en die ruimte wordt binnen de huidige mestwetgeving maximaal benut. Conform eerdere modelstudies zal een verlaging van de P-bemesting weinig tot geen effect hebben op de af- en uitspoeling van fosfaat.

\subsection{Effecten van maatregelen}

De berekende effecten van de maatregelen huidig mestbeleid, onderwaterdrainage, kringloopwijzer+, bodemverbetering en precisiebemesting zijn weergegeven in tabel 4.2. De verandering van de af- en uitspoeling voor het zichtjaar 2027-2030 is uitgedrukt ten opzichte van de af- en uitspoeling die is berekend voor de periode 2010-2013 (zelfde weerjaren). De effecten van de overige maatregelen zijn uitgedrukt in het percentage dat de huidige (2010-2015) af- en uitspoeling verandert.

Tabel 4.2 Effecten huidig mestbeleid 2027-2030, onderwaterdrainage (OWD), bodemverbetering, kringloopwijzer+ en precisiebemesting op de huidige af- en uitspoeling van stikstof naar het oppervlaktewater. Afname van de af- en uitspoeling is negatief uitgedrukt.

\begin{tabular}{|c|c|c|c|c|c|c|c|c|c|c|}
\hline \multirow[t]{2}{*}{ Polder } & \multicolumn{2}{|c|}{ Mestbeleid } & \multicolumn{2}{|c|}{ OWD } & \multicolumn{2}{|c|}{ Kringloopwijzer+ } & \multicolumn{2}{|c|}{ Bodemverbetering } & \multicolumn{2}{|c|}{ Precisie } \\
\hline & $\mathbf{N}$ & $\mathbf{P}$ & $\mathbf{N}$ & $\mathbf{P}$ & $\mathbf{N}$ & $P$ & $\mathbf{N}$ & $\mathbf{P}$ & $\mathbf{N}$ & $P$ \\
\hline Binnenwegse & $-0.7 \%$ & $-0.8 \%$ & & & $-8.6 \%$ & 0 & $-14.7 \%$ & $-0.5 \%$ & $-0.5 \%$ & $0.4 \%$ \\
\hline Oost & $-4.4 \%$ & $-3.3 \%$ & $-15.0 \%$ & $-20.2 \%$ & $-6.1 \%$ & 0 & - & - & $-2.0 \%$ & $0.2 \%$ \\
\hline Bleiswijk & $2.0 \%$ & $-1.5 \%$ & $-0.2 \%$ & $-0.6 \%$ & $-3.2 \%$ & 0 & $-8.1 \%$ & $-2.4 \%$ & $0.1 \%$ & $0.6 \%$ \\
\hline EGB & $-3.0 \%$ & $-2.9 \%$ & $-0.5 \%$ & $-1.0 \%$ & $-8.1 \%$ & 0 & $-0.6 \%$ & $2.2 \%$ & $-1.1 \%$ & $-0.2 \%$ \\
\hline Tweemans & $-1.6 \%$ & $-1.1 \%$ & & & $-1.3 \%$ & 0 & $-8.9 \%$ & $-0.8 \%$ & $-0.8 \%$ & $1.5 \%$ \\
\hline Zuidplas-Noord & $2.2 \%$ & $-2.1 \%$ & & & $-1.2 \%$ & 0 & $-6.8 \%$ & $-1.2 \%$ & $-0.6 \%$ & $0.7 \%$ \\
\hline Zuidplas-Zuid & $2.2 \%$ & $-2.8 \%$ & $-2.6 \%$ & $-7.0 \%$ & $0.6 \%$ & 0 & $-3.9 \%$ & $-0.2 \%$ & $-1.1 \%$ & $0.1 \%$ \\
\hline
\end{tabular}

De effecten zijn alleen berekend voor de percelen waarvan wordt aangenomen dat de maatregel in principe toepasbaar is. Voor onderwaterdrainage zijn dit alle graslandpercelen op veenbodems zonder kleidek met grondwatertrap II, voor kringloopwijzer+ alle gras- en maispercelen (melkveehouderijen) en voor bodemverbetering alleen landbouw op kleibodems. Precisielandbouw wordt in principe op alle landbouwgronden toepasbaar geacht.

De af- en uitspoeling zullen volgens de modelmatige prognose voor de zichtjaren 2027-2030 slechts weinig veranderen. Voor fosfor neemt deze af met enkele procenten. De af- en uitspoeling van stikstof nemen in diverse polders met enkele procenten af, met name waar relatief veel akkerbouw is, terwijl in de andere polders de af- en uitspoeling juist met enkele procenten toenemen. Dit hangt vooral samen met de aannames over de stikstofmestgiften in het recente verleden. Daar waar gebruiksruimten voor mestgiften in het verleden geheel zijn opgevuld, zal de uitspoeling met het huidige mestbeleid iets afnemen. Dat de veranderingen gering zijn, komt vooral omdat de af- en uitspoeling in sterke mate worden beïnvloed door nalevering en kwel. Datzelfde geldt daarmee ook voor precisiebemesting.

Verlaging van het $\mathrm{N}$-bodemoverschot alsmede bodemverbetering geven een grotere verlaging (tot $15 \%$ ) op de af- en uitspoeling van stikstof. Dat geldt ook voor onderwaterdrainage in de Oostpolder en, zij het in iets minder mate, de polder Zuidplas-Zuid. Daarbij nemen ook de af- en uitspoeling van fosfor 
duidelijk af (20 en 7\%). Dit zijn wel onzekere prognoses vanuit een modelstudie in een ander veengebied.

Bedacht moet worden dat de percentages in tabel 4.2 betrekking hebben op de verandering van de totale af- en uitspoeling (landbouw en natuurgronden). Het aandeel van de af- en uitspoeling in de totale nutriëntenbelasting verschilt sterk per polder (zie tabel 4.3). Daarmee is het effect van de maatregelen op de totale nutriëntenbelasting kleiner dan aangegeven in tabel 4.2. Als voorbeeld hiervan is in tabel 4.3 het effect van bodemverbetering op de totale belasting weergegeven.

Uit tabel 4.4 blijkt dat de aansluiting voor Bleiswijk verreweg het meeste effect heeft: de glastuinbouwemissies nemen af met ongeveer $85 \%$ en gezien het grote aandeel van de glastuinbouw in de totale belasting ( $55 \%$ voor $\mathrm{N}$ en $59 \%$ voor $\mathrm{P}$ ) zorgt dit ervoor dat de totale nutriëntenbelasting ongeveer halveert. Voor de andere gebieden met glastuinbouw nemen de emissies met ongeveer een derde af en is het effect op de totale nutriëntenbelasting veel geringer (een paar procent voor ZuidplasNoord en -Zuid en minder dan $1 \%$ voor de overige polders). Dit komt door het geringere aandeel van glastuinbouw in de nutriëntenbelasting en doordat al meer aansluitingen op het riool in de referentieperiode gerealiseerd waren. Dat de afname voor Bleiswijk zo groot is, komt omdat hier pas in 2014 aansluitingen op gang zijn gekomen. Bedacht moet worden dat de maatregel vanaf 2016 in alle polders al gerealiseerd is en de hiermee bereikte emissiereducties (in theorie) dus al zijn opgetreden.

Tabel 4.3 Aandeel af- en uitspoeling op de totale nutriëntenbelasting referentie (2000-2013) en het effect van bodemverbetering op de totale belasting.

\begin{tabular}{|c|c|c|c|c|}
\hline \multirow[t]{2}{*}{ Polder } & \multicolumn{2}{|c|}{$\begin{array}{l}\text { Aandeel uit en afspoeling landbouwgrond } \\
\text { op de totale belasting }\end{array}$} & \multicolumn{2}{|c|}{$\begin{array}{l}\text { Verandering totale nutriëntenbelasting } \\
\text { door bodemverbetering }\end{array}$} \\
\hline & $\mathbf{N}$ & $\mathbf{P}$ & $\mathbf{N}$ & P \\
\hline Bleiswijk & $19 \%$ & $21 \%$ & $-1.5 \%$ & $-0.5 \%$ \\
\hline Eendragts & $22 \%$ & $31 \%$ & $-1.7 \%$ & $-0.9 \%$ \\
\hline Oost & $22 \%$ & $50 \%$ & & \\
\hline Tweemans & $87 \%$ & $89 \%$ & $-7.7 \%$ & $-0.7 \%$ \\
\hline Wilde Veenen & $87 \%$ & $89 \%$ & $-9.5 \%$ & $-2.0 \%$ \\
\hline Zuidplas-Noord & $43 \%$ & $44 \%$ & $-2.9 \%$ & $-0.5 \%$ \\
\hline
\end{tabular}

De effecten voor glastuinbouw (volledig aansluiten op riolering) zijn weergegeven in tabel 4.4. De effecten van volledige aansluiting zijn geprojecteerd op de aansluiting die in de referentieperiode 2010-2013 gerealiseerd was.

Tabel 4.4 Effecten volledige aansluiting van glastuinbouw op de riolering.

\begin{tabular}{|c|c|c|c|c|c|c|c|c|}
\hline \multirow[t]{2}{*}{ Polder } & \multicolumn{2}{|c|}{$\begin{array}{l}\text { Belasting } \\
\text { glastuinbouw } \\
\text { referentie } \\
(2010-2013) \\
\end{array}$} & \multicolumn{2}{|c|}{$\begin{array}{l}\text { Aandeel } \\
\text { glastuinbouw in } \\
\text { totale belasting } \\
(2010-2013) \\
\end{array}$} & \multicolumn{2}{|c|}{$\begin{array}{c}\text { Verlaging belasting } \\
\text { glastuinbouw bij volledige } \\
\text { aansluiting op riool }\end{array}$} & \multicolumn{2}{|c|}{$\begin{array}{c}\text { Verandering totale } \\
\text { nutriëntenbelasting door } \\
\text { rioolaansluiting }\end{array}$} \\
\hline & $\mathbf{N}($ ton/j) & $P($ ton $/ \mathrm{j})$ & $\mathbf{N}$ & P & $\mathbf{N}($ ton / j) & $P($ ton/j) & $\mathbf{N}$ & $\mathbf{P}$ \\
\hline Wilde Veenen & 0.61 & 0.09 & $1 \%$ & $1 \%$ & 0.20 & 0.03 & $-0.8 \%$ & $-0.8 \%$ \\
\hline Binnenwegse & 0.11 & 0.02 & $3 \%$ & $4 \%$ & 0.04 & 0.01 & $-0.1 \%$ & $-0.1 \%$ \\
\hline Bleiswijk & 108.26 & 15.75 & $55 \%$ & $59 \%$ & 91.45 & 13.50 & $-47.6 \%$ & $-50.4 \%$ \\
\hline Tweemans & 0.28 & 0.04 & $2 \%$ & $2 \%$ & 0.09 & 0.01 & $-0.6 \%$ & $-0.6 \%$ \\
\hline Oost & 0.04 & 0.01 & $6 \%$ & $6 \%$ & 0.01 & 0.003 & $-0.2 \%$ & $-0.3 \%$ \\
\hline EGB & - & - & - & - & - & - & - & - \\
\hline Eendragts & 0.39 & 0.06 & $4 \%$ & $5 \%$ & 0.13 & 0.02 & $-0.3 \%$ & $-0.5 \%$ \\
\hline Zuidplas-Noord & 11.72 & 1.71 & $31 \%$ & $36 \%$ & 3.79 & 0.57 & $-4.8 \%$ & $-5.7 \%$ \\
\hline Zuidplas-Zuid & 8.10 & 1.22 & $20 \%$ & $23 \%$ & 2.70 & 0.41 & $-2.8 \%$ & $-3.2 \%$ \\
\hline
\end{tabular}




\section{Effecten van combinaties aan maatregelen}

De hierboven beschreven maatregeleffecten gelden voor afzonderlijke maatregelen. Bij het combineren van maatregelen valt het gecombineerde effect hoogstwaarschijnlijk lager uit dan de som van de afzonderlijke effecten. Dat is zeker het geval wanneer de maatregelen overlap vertonen en/of op hetzelfde deelsysteem/gebied worden toegepast. In een recent rapport over het effect van maatregelen in het kader van de Nationale Analyse Waterkwaliteit wordt de volgende formule gebruikt om het gecombineerde effect te berekenen (Groenendijk et al., in prep.):

$$
\begin{aligned}
\text { Totaal effect }= & 1-(1-\text { deeleffect bronmaatregelen }) \times(1-\text { deeleffect routemaatregelen }) \\
& \text { x }(1-\text { deeleffect effectgerichte maatregelen })
\end{aligned}
$$

Het deeleffect van een bepaald type maatregelen (bron, route of effectgericht) is hierbij als volgt gedefinieerd, waarbij het maatregeleffect is uitgedrukt in een fractie in plaats van een percentage:

$$
\begin{aligned}
\text { Deeleffect } & =1 \times \text { effect_beste_maatregel }+0.5 \times \text { effect_op_een_na_beste_maatregel } \\
& +0.25 \times \text { effect_op_twee_na_beste_maatregel }+0.125 \times \ldots \ldots \ldots .
\end{aligned}
$$

De landbouwmaatregelen in deze studie zijn te typeren als bronmaatregel (mestbeleid, kringloopwijzer+, bodemverbetering en precisiebemesting) en routemaatregel (onderwaterdrainage). Het toepassen van bovenstaande methode leidt tot de gecombineerde effecten die zijn weergegeven in tabel 4.5 (exclusief het aansluiten van de glastuinbouw op het riool). Waarschijnlijk geven deze percentages een overschatting van het effect, gezien de overlap tussen bepaalde maatregelen. Zo liggen bijvoorbeeld deels dezelfde maatregelen ten grondslag aan 'kringloopwijzer + ' en 'precisiebemesting'. Daarnaast zijn niet alle maatregelen te combineren op eenzelfde landbouwperceel. Zo is onderwaterdrainage bijvoorbeeld niet overal toepasbaar. Vandaar dat tabel 4.5 een bovengrens geeft voor het te verwachten gecombineerde effect en zal het effect waarschijnlijk

\begin{tabular}{|c|c|c|}
\hline \multirow[t]{2}{*}{ Polder } & \multicolumn{2}{|c|}{ Gecombineerd effect landbouwmaatregelen op af- en uitspoeling } \\
\hline & $\mathbf{N}$ & $\mathbf{P}$ \\
\hline Binnenwegse & $-19.2 \%$ & $-0.9 \%$ \\
\hline Oost & $-22.5 \%$ & $-22.8 \%$ \\
\hline Bleiswijk & $-9.6 \%$ & $-3.6 \%$ \\
\hline EGB & $-10.4 \%$ & $-3.4 \%$ \\
\hline Tweemans & $-10.1 \%$ & $-1.1 \%$ \\
\hline Zuidplas-Noord & $-7.3 \%$ & $-2.5 \%$ \\
\hline Zuidplas-Zuid & $-6.5 \%$ & $-9.7 \%$ \\
\hline
\end{tabular}
lager uitvallen.

Tabel 4.5 Grove inschatting van het gecombineerde effect van de in deze studie doorgerekende landbouwmaatregelen (zie tabel 4.2).

Hoewel de berekende effecten van de beschouwde maatregelen op de totale nutriëntenbelasting gering zijn, kunnen maatregelen gestimuleerd worden voor verbetering van de nutriëntenbenutting en bodembeheer, omdat deze in de regel bijdragen aan een positiever bedrijfsresultaat.

Onderwaterdrainage draagt naast verbetering van de waterkwaliteit ook bij aan het afremmen van maaivelddaling. Bufferstroken kunnen effectief zijn om risico's van oppervlakkige afstroming te beperken. Deze hebben dan tegelijkertijd een positieve invloed op de biodiversiteit.

Om N- en P-concentraties in het oppervlaktewater te verlagen, kan het effectiever zijn om maatregelen te nemen waardoor de retentie in de watergangen toeneemt. Dit kan door vergroening van de slootranden (kruidenrijke akkerranden, bufferstroken), hetgeen ook bijdraagt aan biodiversiteit, maar ook door de sloten op diepte houden, slootmaaisel te verwijderen en vertrapping van oevers te voorkomen. De potentie hiervan kan ingeschat worden met een tool die recentelijk door de WUR is ontwikkeld (Gerven, 2019, in prep.). Daarbij wordt aanbevolen om meer kennis op te 
bouwen over de huidige retentie, bijvoorbeeld door monitoring van de kwaliteit van de waterbodems en de hoeveelheden en samenstelling van bagger en waterplanten die uit de watergangen worden verwijderd.

\subsection{Maatwerk op perceelniveau}

De bronnenanalyse geeft informatie op het niveau van de bemalingsgebieden. De $\mathrm{N}$ - en P-toestand van de toplaag geeft, in combinatie met informatie die ook op perceelniveau bekend is (maaiveldhoogte, grondwatertrap, bodemtype), houvast hoe boeren op perceelniveau met maatregelen de verliezen naar water kunnen beperken en zo een bijdrage kunnen leveren aan verbetering van de waterkwaliteit op polderniveau. Juist hiermee kunnen agrariërs de nutriëntenefficiency verbeteren met uitgekiende mestpraktijk. Zo kan op percelen waar een hoge fosfaatbufferindex is minder dierlijke mest worden toegediend zonder dat dit ten koste gaat van de gewasopbrengsten. Het toedienen van die mest op percelen met een lage bufferindex zorgt op bedrijfsniveau voor een hogere P-benutting en lagere P-verliezen (Verhoeven, 2018; Ros, 2019; Schipper, 2016). In 2021 komt voor de mestwetgeving een nieuwe systematiek om de P-toestand van bodems te bepalen. Daarmee kunnen de mestgiften beter afgestemd worden op de behoefte van het gewas, rekening houdend met de nalevering vanuit de bodem.

In het Kennisimpulsproject Nutriënten is een landelijke percelenkaart gegenereerd die de beloftevolste maatregelen geeft (Groenendijk, 2019, in prep.). Deze kaart kan verfijnd worden door de daarin gebruikte openbare data van de bouwvoor te vervangen door de Eurofins data, die voor de onderhavige studie zijn aangeschaft. Ook is een methodiek voor de Nationale Analyse Waterkwaliteit ontwikkeld om met perceelinformatie de effectiviteit van bufferzones in te schatten (Groenendijk, 2019, in prep.).

Als naast de hier verzamelde bodemeigenschappen ( $\mathrm{N}$-nalevering, grondwatertrap) op perceelniveau bekeken wordt wat de gewasopbrengsten zijn geweest, is voor de boer de N-benutting per perceel bekend. Met die informatie kan hij beter sturen op de hoogte en timing van de stikstofmestgiften. 


\section{$5 \quad$ Conclusies en aanbevelingen}

\section{$5.1 \quad$ Conclusies}

\section{Nutriëntenbelasting}

De onderzochte polders in Schieland vertonen vooral door de hydrologie (kwel/wegzijging en wateraanvoer) grote verschillen qua totale nutriëntenbelasting (per hectare), een factor 2 voor stikstof $(\mathrm{N})$ en een factor 3 voor fosfor $(\mathrm{P})$. De sturendste factor op de hoogte van de diffuse N- en P-belasting is de dynamiek met het grondwater: polders met overwegend infiltratie vertonen substantieel lagere verliezen naar het oppervlaktewater dan polders met kwel. Om die reden is de belasting in polder EGB en Oost minimaal $x \%$ lager dan de overige polders. Als tweede factor is het landgebruik van grote invloed.

Polders met veel glastuinbouw (Zuidplaspolder-Zuid, Zuidplaspolder-Noord en vooral Polder Bleiswijk) hebben de grootste belasting (per hectare) voor zowel N als P. Daarna volgen de akkerbouwpolders (Tweemanspolder en Polder de Wilde Venen), waarbij de belasting voornamelijk bestaat uit af- en uitspoeling vanuit het landelijke gebied. De veenweidepolders (Polder EGB en de Oostpolder) en de polders met veel stedelijk gebied (Eendragtspolder en vooral Binnenwegse polder) hebben de laagste nutriëntenbelasting voor zowel $\mathrm{N}$ als $\mathrm{P}$.

Het landelijke gebied levert voor elke polder een vergelijkbare bijdrage (per hectare) via af- en uitspoeling, ondanks ruimtelijke verschillen in nutriëntentoestand, bodemtype en hydrologie. De ruimtelijke verschillen in bodemtype en hydrologie zorgen wel voor een andere verdeling van de af- en uitspoeling naar de onderliggende bronnen. Zo is de nalevering vanuit de bodem de belangrijkste bron in de veenweidegebieden (Polder EGB en Oostpolder) en is de bijdrage van actuele/historische bemesting het grootst in de akkerbouwpolders (Tweemanspolder en Polder de Wilde Venen).

De $\mathrm{N}$ - en P-toestand van de toplaag (10 $\mathrm{cm}$ bij grasland, $25 \mathrm{~cm}$ bij bouwland) tonen grote ruimtelijke verschillen. Het is onduidelijk of informatie over deze ruimtelijke verschillen leidt tot wijzigingen in het beeld van de per bemalingsgebied berekende af- en uitspoeling. Berekeningen in deze andere veenweidegebieden laten zien dat de belangrijkste P-verliezen optreden vanuit de diepere bodemlagen, vooral als sprake is van kwel. De eventuele over- of onderschatting van de af- en uitspoeling uit de toplaag zal de totale af- en uitspoeling en daarmee de bekende herkomst waarschijnlijk niet wezenlijk veranderen.

\section{Handelingsperspectief om nutriëntenbelasting te verminderen}

Qua herkomst van de nutriënten zijn er grote verschillen binnen Schieland voor zowel N als $\mathrm{P}$, veroorzaakt door verschillen in landgebruik, nutriëntentoestand, bodemtype en hydrologie. Voor de haalbaarheid van de waterkwaliteitsdoelen is het belangrijk om te weten welk deel van de nutriëntenbelasting opgevat kan worden als achtergrondbelasting.

Een deel van de belasting is afkomstig van bronnen die beleidsmatig aangewezen kunnen worden als natuurlijk of seminatuurlijk. Deze bronnen worden ook wel gekarakteriseerd als moeilijk of nietbeïnvloedbare bronnen. Het totale aandeel hiervan wordt beleidsmatig aangeduid als theoretische achtergrondbelasting. Bij de berekening van deze achtergrondbelasting is ervan uitgegaan dat de volgende bronnen als natuurlijk of seminatuurlijk worden beschouwd: uitspoeling vanuit natuurgronden, uitspoeling vanuit landbouwgronden die veroorzaakt wordt door kwel, nalevering, depositie en eerder geïnfiltreerd oppervlaktewater, atmosferische depositie op open water en kwel die direct uittreedt naar oppervlaktewater.

Tabel 5.1 geeft aan welk deel van de totale belasting bestaat uit 'achtergrondbelasting' en de resterende 'antropogene'. Inlaatwater is hierbij gerekend onder antropogeen, hoewel dit deels ook 
beïnvloed wordt door natuurlijke bronnen. Dit onderscheid is voor de grote wateren - waaruit wordt ingelaten - echter niet in deze studie te maken.

Voor stikstof varieert deze achtergrondbelasting tussen de 30 en $70 \%$ (gemiddeld 48\%). De achtergrondbelasting van stikstof is relatief laag in de polders met veel glastuinbouw (Bleiswijk, Zuidplas-Noord en -Zuid) en de polders met veel akkerbouw (Wilde Veenen en Tweemans). Voor fosfor is de achtergrondbelasting een stuk hoger, namelijk gemiddeld $67 \%$ (variërend tussen 35 en $85 \%)$. Dit komt vooral door een grotere bijdrage in de uitspoeling door nalevering en kwel. In de akkerbouwpolders en de veenweidepolders met infiltratie (EGB en Oostpolder) is een belangrijk deel afkomstig van 'historische bemesting'.

Tabel 5.1 Onderverdeling nutriëntenbelasting in achtergrond en antropogene belasting. Onder achtergrondbelasting is gerekend: nalevering bodem, atmosferische depositie, kwel, infiltratie, af- en uitspoeling natuurgronden en stedelijk groen, excretie van honden, bladval en eenden voeren. Inlaat is gerekend onder antropogeen, hoewel de kwaliteit van het inlaatwater ook deels door natuurlijke bronnen wordt bepaald. Dit aandeel kan voor de onderhavige studie echter niet worden ingeschat.

\begin{tabular}{|c|c|c|c|c|}
\hline \multirow[b]{2}{*}{ Polder } & \multicolumn{2}{|c|}{ Achtergrondbelasting ( $\%)$} & \multicolumn{2}{|c|}{ Antropogene belasting $(\%)$} \\
\hline & $\mathbf{N}$ & $\mathbf{P}$ & $\mathbf{N}$ & $\mathbf{P}$ \\
\hline De Wilde Veenen & $36 \%$ & $70 \%$ & $64 \%$ & $30 \%$ \\
\hline Bleiswijk & $31 \%$ & $36 \%$ & $69 \%$ & $64 \%$ \\
\hline Tweemans & $38 \%$ & $71 \%$ & $62 \%$ & $29 \%$ \\
\hline EGB & $54 \%$ & $72 \%$ & $46 \%$ & $28 \%$ \\
\hline Eendragts & $71 \%$ & $84 \%$ & $29 \%$ & $16 \%$ \\
\hline Zuidplas-Noord & $40 \%$ & $53 \%$ & $60 \%$ & $47 \%$ \\
\hline Zuidplas-Zuid & $51 \%$ & $60 \%$ & $49 \%$ & $40 \%$ \\
\hline
\end{tabular}

In polders met veel glastuinbouw (Zuidplas-Zuid, Zuidplas-Noord en vooral Bleiswijk) is de reductie in lozingen een effectieve maatregel (geweest) om de $\mathrm{N}$ - en P-verliezen naar het oppervlaktewater te verkleinen. In principe kunnen de emissies door aansluiting op het riool nog lager zijn of worden indien er bij de uitvoering geen enkele foute aansluiting wordt gemaakt en er op de bedrijven geen morsingen of andere calamiteiten plaatsvinden. Zoals aangegeven in hoofdstuk 2, is er van uitgegaan dat bij aansluiting op het riool de emissies vanuit substraatteelt naar water met $80 \%$ afnemen, terwijl in EmissieRegistratie wordt uitgegaan van $95 \%$.

De berekende effecten van landbouwmaatregelen zijn vrij gering. De af- en uitspoeling kunnen weliswaar met enkele procenten (tot zo'n 15\%) afnemen door betere benutting van de nutriënten met bodemverbeterende en 'Kringloopwijzer-plus' maatregelen en waar mogelijk onderwaterdrainage, maar omdat de af- en uitspoeling van landbouwgronden geen dominant aandeel hebben in de totale nutriëntenbelasting is het effect van deze maatregelen op de totale belasting gering.

Voor $\mathrm{P}$ is het handelingsperspectief voor agrarisch bodem- en bemestingsbeheer klein in de meeste polders, vanwege het grote aandeel 'achtergrondbelasting' (vaak groter dan 70\%), en omdat de resterende 'antropogene belasting' vaak vooral bestaat uit 'historische bemesting' waarop moeilijk te sturen is binnen het huidige mestbeleid en de huidige mestmarkt. Een uitgekiende mestverdeling die rekening houdt met de P-buffering van de bodem (d.w.z. de P-bufferindex, die deels wordt ingevoerd na 2021) kan zorgen voor een netto verlaging van de P-concentratie in het bodemvocht en daardoor ook de af- en uitspoeling verlagen.

Voor $\mathrm{N}$ is het handelingsperspectief op korte termijn in het algemeen beter dan voor $\mathrm{P}$, vooral voor de akkerbouwpolders (Tweemanspolder en Polder de Wilde Veenen). Dit komt doordat $\mathrm{N}$ minder goed bindt aan de bodem dan $\mathrm{P}$, waardoor $\mathrm{N}$ sneller uit- en afspoelt en landbouwmaatregelen vaak eerder en een groter effect hebben. Het positieve effect van maatregelen die ingrijpen op het $\mathrm{N}$-bodemoverschot en de bodemstructuur in akkerbouwmatige teelten wordt weerspiegeld door de 
grote bijdrage van 'actuele bemesting' aan de totale belasting. Een goede bodemvruchtbaarheid, als resultante van een doordacht bouwplan, bodembeheer en bemesting zorgt hier voor meer buffering in de bodem en minder $\mathrm{N}$-verliezen. Mogelijkheden voor een hogere benutting hebben vooral te maken met de gewasopvolging in het bouwplan en het tijdstip van dierlijke mesttoediening (in akkerbouw) als wel het tijdstip van toedienen van kunstmest en organische mest (grasland).

Het handelingsperspectief voor verlaging van de nutriëntenbelasting is het grootst in de polder met veel glastuinbouw. In de veenweide- en akkerbouwpolders (EGB en Oostpolder) is een belangrijk deel afkomstig is van 'historische bemesting'. Deze bron is niet meer te beïnvloeden, maar met ander landgebruik en maatwerk in bemesting kan de invloed ervan wel worden beperkt.

\subsection{Aanbevelingen}

Met de berekende onderverdeling in wel/niet/moeilijk beïnvloedbare (semi)natuurlijke en antropogene bronnen kunnen keuzes voor het afleiden van achtergrondconcentraties, het eventueel bijstellen van waterkwaliteitsdoelen en de inzet voor maatregelen worden onderbouwd. De studie laat ook zien dat het aan te bevelen is om Eurofins data in de bronnenanalyse mee te nemen. Dit geeft een beter zicht op de handelingsperspectieven voor landbouw(maatwerk)maatregelen. Ook is daarbij aan te bevelen om met deze informatie de ECHO-methode te verfijnen door de herschikkingsprocedure zo aan te passen dat de $\mathrm{P}$ - en $\mathrm{N}$-toestand van de toplaag meegewogen worden bij de selectie van de rekenplots.

Voor de polder Bleiswijk was het aandeel van glastuinbouw op de nutriëntenbelasting groot. Aanbevolen wordt om hier met handhaving en communicatie te volgen of er situaties zijn waar de aansluitingen op het riool niet goed zijn aangelegd en of morsingen en calamiteiten die leiden tot lozingen van het gietwater kunnen worden voorkomen.

Hoewel de berekende effecten van de beschouwde maatregelen op de totale nutriëntenbelasting gering zijn, kunnen maatregelen worden gestimuleerd voor verbetering van de nutriëntenbenutting en bodembeheer, omdat deze in de regel bijdragen aan een positiever bedrijfsresultaat én een betere waterkwaliteit. Onderwaterdrainage draagt naast verbetering van de waterkwaliteit ook bij aan het afremmen van maaivelddaling. Bufferstroken kunnen effectief zijn om risico's van oppervlakkige afstroming te beperken. Deze hebben dan tegelijkertijd een positieve invloed op de biodiversiteit.

Om N- en P-concentraties in het oppervlaktewater te verlagen, kan het effectiever zijn om maatregelen te nemen waardoor de retentie in de watergangen toeneemt. Dit kan door vergroening van de slootranden (kruidenrijke akkerranden, bufferstroken), hetgeen ook bijdraagt aan biodiversiteit, maar ook door de sloten op diepte te houden, slootmaaisel te verwijderen en vertrapping van oevers te voorkomen. De potentie hiervan kan ingeschat worden met een tool die recentelijk door de WUR is ontwikkeld (Gerven, 2019 in prep.). Daarbij wordt aanbevolen om meer kennis op te bouwen over de huidige retentie, bijvoorbeeld door het monitoren van de kwaliteit van de waterbodems en de hoeveelheden en samenstelling van bagger en waterplanten die uit de watergangen worden verwijderd.

Aanbevolen wordt om met monitoring meer en betrouwbaardere informatie te verzamelen over de hoeveelheden die worden ingelaten en uitgemalen. 


\section{Literatuur}

Akker, J.J.H. van den, F. de Vries, G.D. Vermeulen, M.J.D. Hack-ten Broeke en T. Schouten, 2012. Risico op ondergrondverdichting in het landelijk gebied in kaart. Wageningen, Alterra, AlterraRapport 2409.

Akker, J.J.H. van den, R.F.A. Hendriks, I.E. Hoving, J. van Kleef, B. Meerkerk, M. Pleijter en A. van den Toorn, 2013. Pilot onderwaterdrains Krimpenerwaard. Wageningen, Alterra Wageningen UR, Alterra-rapport 2466.

Akker, Jan J.H.; Idse Hoving, Rob Hendriks en Martin Knotters 2019. Onderwaterdrains zijn effectief. Wageningen Environmental Research (Wageningen Environmental Research rapport 2922).

Boekel, E.M.P.M. van, P. Groenendijk en L.V. Renaud, 2016. Bronnen van nutriënten in het oppervlaktewater in het beheergebied van Wetterskip Fryslân; studie naar de herkomst en beïnvloedbaarheid van stikstof en fosfor in het oppervlaktewater voor zes polders in het beheergebied van Wetterskip Fryslân. Wageningen, Alterra, Alterra-rapport 2727.

Boekel, E.M.P.M. van, J. Roelsma, H.T.L. Massop, H.M. Mulder, P.C. Jansen, L.V. Renaud, R.F.A. Hendriks en P.N.M. Schipper, 2015. Achtergrondconcentraties in het oppervlaktewater van HHNK: Hoofdrapport; Analyse achtergrondconcentraties voor stikstof en fosfor op basis van wateren nutriëntenbalansen voor het beheergebied van HHNK. Wageningen, Alterra, Alterra-rapport 2475.

Boekel, E.M.P.M., Smit, A.A.M.F.R., Mulder, H.M., Groenendijk P., 2013. Procedure afleiden regionale af- en uitspoelingcijfers voor stikstof en fosfor (herschikkingsprocedure). Wageningen, Alterra.

Boekel, E.M.P.M. van, P.N.M. Schipper, R.F.A. Hendriks, H.T.L. Massop, H.M. Mulder en J. Roelsma, 2013. Herkomst nutriëntenbelasting afvoergebieden HDSR, pilotstudie ECHO: regionale bronnenanalyse nutriëntenbelasting: Keulevaart, Eiland van Schalkwijk, Langbroekerwetering en Zegveld. Wageningen, Alterra, Alterra-rapport 2408.

Boekel, E.M.P.M. van, P. Bogaart, L.P.A. van Gerven, T. van Hattum, R.A.L. Kselik, H.T.L. Massop, H.M. Mulder, P.E.V. van Walsum en F.J.E. van der Bolt, 2012. Evaluatie Landbouw en KRW. Evaluatie meststoffenwet 2012: deelrapport ex post. Wageningen, Alterra, Alterra-rapport 2326.

Emissieregistratie, 2016. Emissieschattingen Diffuse Bronnen - Lozingen vanuit glastuinbouw.

Van Gerven, L.P.A., in prep. Zuiveringstool oppervlaktewaterkwaliteit. Een rekeninstrument ter voorspelling van het effect van zuiveringsmaatregelen op de $\mathrm{N}$ - en $\mathrm{P}$-concentraties in het oppervlaktewater.

Grinsven, H. van, A. Bleeker, S. van der Sluis, M. van Schijndel, J. van Dam, A. Tiktak, F. van Gaalen, R. den Uyl, S. Kruitwagen, J. Beck, G. Velthof, O. Schoumans, C. de Lauwere, 2017. Evaluatie Meststoffenwet 2016: syntheserapport. PBL-rapport 2258, Planbureau voor de Leefomgeving, Den Haag.

Groenendijk, P., L.P.A. van Gerven, E.M.P.M. van Boekel, in prep. Maatregelen op en rond landbouwpercelen ter vermindering van de af- en uitspoeling van nutriënten. Achtergrondinformatie over maatregelen ten behoeve van de Nationale Analyse Waterkwaliteit.

Groenendijk, P., L. Renaud, H. Luesink, P.W. Blokland \& T. de Koeijer, 2016. Gevolgen van mestnormen volgens het $5^{e}$ Actieprogramma voor nitraat en $\mathrm{N}$ - en P-belasting van het oppervlaktewater. Wageningen, Alterra, Alterra-rapport 2647.

Groenendijk, P., R.F.A. Hendriks, F.J.E. van der Bolt, H.M. Mulder, 2014. Bronnen van diffuse nutriëntenbelasting van het oppervlaktewater. Evaluatie Meststoffenwet 2012: deelrapport ex post. Wageningen, Alterra, Alterra-rapport 2328.

Groenendijk, P., E. van Boekel, L. Renaud, A. Greijdanus, R. Michels, T. de, Koeijer, 2016. Landbouw en de KRW-opgave voor nutriënten in regionale wateren: het aandeel van landbouw in de $K R W$ opgave, de kosten van enkele maatregelen en de effecten ervan op de af- en uitspoeling uit landbouwgronden. Wageningen Environmental Research rapport 2749.

Groenendijk, P., L.P.A. van Gerven, E.M.P.M. van Boekel, in prep. Maatregelen in het landelijk gebied ter vermindering van nutriëntengehalten in het oppervlaktewater. Wageningen, Wageningen Environmental Research. 
Hazeu, G.W., C. Schuiling, G.J. Dorland, G.J. Roerink, H.S.D. Naeff en R.A. Smidt, 2010. Landelijk Grondgebruiksbestand Nederland versie 7 (LGN7); Vervaardiging, nauwkeurigheid en gebruik. Wageningen, Alterra Wageningen UR (University \& Research centre), Alterra-rapport 2548.

Hendriks, R.F.A. en J.J.H. van den Akker, 2012. Effecten van onderwaterdrains op de waterkwaliteit in veenweiden. Modelberekeningen met SWAP-ANIMO voor veenweide-eenheden naar veranderingen van de fosfor-. stikstof- en sulfaatbelasting van het oppervlaktewater bij toepassing van onderwaterdrains in het westelijke veenweidegebied. Wageningen, Alterra Wageningen UR Alterrarapport 2354

Hendriks, R.F.A., J.J.H. van den Akker, K. van Houwelingen, J. van Kleef, M. Pleijter en A. van den Toorn, 2013. Pilot onderwaterdrains Utrecht. Wageningen, Alterra Wageningen UR. Alterra-rapport 2479.

Hendriks, R.F.A., J.J.H. van den Akker, P.C. Jansen en H.Th.L. Massop, 2014. Effecten van onderwaterdrains in peilvak 9 van polder Groot-Wilnis Vinkeveen. Modelstudie naar de effecten van onderwaterdrains op maaivelddaling, waterbeheer, wateroverlast en waterkwaliteit in peilvak 9. Wageningen, Alterra Wageningen UR, Alterra-rapport 2480.

Kroes, J.G., E.M.P.M. van Boekel, F.J.E. van der Bolt, L.V. Renaud en J. Roelsma, 2011. ECHO, een methodiek ter ondersteuning van waterbeleid; methodiekbeschrijving en toepassing Drentse Aa. Wageningen, Alterra, Alterra-rapport 1913.

Kroes, J.P., P. Groenendijk, J. Huygen, 1999. Hydrologie voor STONE: berekeningen met SWAP 2.0. Technical Document 57. Alterra, Research Instituut voor de Groene Ruimte, Wageningen.

Klijn, 1997. Vertaaltabellen bodem voor MOZART-SMART-DEMNAT, T2178. Delft, Waterloopkundig Laboratorium.

Kroon, T., P. Finke, I. Peerenboom en A. Beuzen, 2001. Redesign STONE. De nieuwe schematisatie voor STONE; de ruimtelijke indeling en de toekenning van hydrologische en bodemchemische parameters. Lelystad, RIZA, rapport 2001.017.

Kros, Hans, Debby van Rotterdam, Arjan Reijneveld, Wim de Vries en Gerard Ros 2017. Gebiedsgericht inzicht in effecten van landbouwmaatregelen op emissies van stikstof en fosfor. Water Matters: Kenniskatern voor Waterprofessionals - Dutch edition (2017)1. - p. 4 - 7.

Linden, W. van der, e.a. 2008. Grondwatermodellering Rivierenland (MORIA). Deltares / TNO-rapport 2008-U-R0827/A, Utrecht.

Ros, G.H., P. Groenendijk en J. Rozemeijer, 2018. Advies Nutriëntenvisie Rijn-Oost. Inventarisatie van knelpunten en oplossingen om nutriëntenverliezen uit de landbouw terug te dringen. NMI-rapport 1589.N.18.21, 31 pp.

Ros G.H., H. Kros, P. van Vliet P \& K. van Duijvendijk, 2018. Kwantificering nutriëntensituatie van de bodem in het beheergebied van Wetterskip Fryslân. NMI-rapport 1708.N.17, 27pp.

Ros G.H. \& S.E. Verweij, 2019. Ontwikkeling maatwerkpakketten waterkwaliteit. Deel 1. Ruimtelijke gebiedsanalyse. NMI-rapport 1742.N.18, 44 pp.

Ros G.H. en Merel Honderbrink 2019. Proefpolder kringlooplandbouw, een compilatie van onderzoeksgegevens. Rapport Waternet 2019.

Rotterdam, D. van, H. Honkoop, J. van Milternburg en A. Koelemeijer. Pilot kringlooppakket, ontwikkeling pakket en toetsing in de praktijk. Resultaten 2018. NMI-rapport 1706.N.18., 26 pp.

Rozemeijer, J., I.G.A.M. Noij, E.M.P.M. van Boekel \& V. Linderhof, 2016. Expertbeoordeling van landbouwmaatregelen voor oppervlaktewaterkwaliteit. $\mathrm{H} 2 \mathrm{O}$ online 2016, 28 nov.

Schipper, P., R. Hendriks, H. Massop, E. van Boekel, 2016. Belasting van waterlichamen in de Krimpenerwaard met stikstof en fosfor. Wageningen, Wageningen Environmental Research rapport 2738.

Hendriks, Rob, Jan van den Akker en Joost Heijkers 2018. Delfact Onderwaterdrains. https://www.stowa.nl/deltafacts/zoetwatervoorziening/droogte/onderwaterdrains

WiBo, 2015. Watersysteemstudie Krimpen aan den IJssel. Witteveen+Bos rapport in opdracht van Hoogheemraadschap Schieland en Krimpenerwaard.

Salm, C. van der, P. Groenendijk, R. Hendriks, L. Renaud \& H. Massop (2015), Opties voor benutten van de bodem voor schoon oppervlaktewater. Wageningen, Alterra, Alterra-rapport 2588.

Velthof, G.L., W. Bussink, W. van Dijk, P. Groenendijk, J.F.M. Huijsmans, W.A.J. van Pul, J.J. Schröder, Th.V. Vellinga en O. Oenema, 2013. Protocol gebruiksvoorschriften dierlijke mest, versie 1.0. Wageningen, Wettelijke Onderzoekstaken Natuur \& Milieu. WOt-rapport 120. 98 blz. 
G.L. Velthof, F.H. Kistenkas, P. Groenendijk, E.M.P.M. van Boekel en O. Oenema, 2018. Wettelijk instrumentarium voor landbouwmaatregelen om waterkwaliteit te verbeteren. Realisatie van nutriëntendoelstellingen uit de Kaderrichtlijn Water. WOt-rapport 129, Wageningen mei 2018.

Verloop, Koos; Agtmaal, Maaike van; Busink, Wim; Eekeren, Nick van; Groenendijk, Piet; Jansen, Stefan; Noij, Gert-Jan; Zanen, Marleen, 2018. Achtergronden bij informatie in de BOOTlijst factsheets. Wageningen Plant Research, Business unit Agrosysteemkunde, Rapport WPR 842.

Verhoeven, Frank en Gerard Ros 2018. Kansenkaart waterkwaliteit, slimme combinaties. V-focus februari 2018.

Verweij, S., P. van Vliet, G.H. Ros, 2018. Bodemkaarten Hoogheemraadschap Schieland en Krimpenerwaard. NMI Rapport 1736.N.18. Nutriënten Management Instituut NMI B.V., Wageningen.

Vries, F. de, W.J.M. de Groot, T. Hoogland,. J. Denneboom, 2003. De bodemkaart van Nederland digitaal; Toelichting bij inhoud, actualiteit en methodiek en korte beschrijving van additionele informatie. Wageningen, Alterra, Alterra-rapport 811.

Woestenburg, M. en T.P. van Tol-Leenders, 2011. Sturen op schoon water: eindrapportage project Monitoring Stroomgebieden.

Wösten, J.H.M., F. de Vries, J. Denneboom en A.F. van Holst, 1988. Generalisatie en bodemfysische vertaling van de Bodemkaart van Nederland, 1: 250 000, ten behoeve van de Pawnstudie. Stiboka, Wageningen. Rapport 2055.

Zanen M., P. Belder, W. Cuijpers en M. Bos, 2011. Literatuurstudie deel 1: Duurzaam bodembeheer \& Functionele Agrobiodiversiteit in de bodem. Interregproject BodemBreed. 37 p. 


\section{Bijlage 1 Herschikkingsprocedure}

\section{STONE-schematisering}

STONE (Samen Te Ontwikkelen Nutriënten Emissiemodel) is een landelijk model dat erop gericht is om op nationale schaal de effecten van nationaal of Europees landbouw- en milieubeleid en de ontwikkelingen in de landbouwsector op de uitspoeling van stikstof en fosfor naar grond- en oppervlaktewater te kwantificeren.

De ruimtelijke indeling voor STONE is opgesteld door Kroon (2001) en is gemaakt op basis van hydrologische en bodemchemische eigenschappen. Nederland is hierbij ingedeeld in 6405 ruimtelijke eenheden (plots) voor het landelijk gebied, één plot voor het bebouwde gebied en één plot voor water. Een plot bestaat uit meerdere gridcellen van $250 * 250 \mathrm{~m}$ die dezelfde unieke combinatie van eigenschappen hebben. De gridcellen kunnen verspreid liggen in een gebied.

De ruimtelijke verdeling is gebaseerd op vijf basiselementen:

- hydrologische hoofdindeling (hydrotypen, drainage-groepen, grondwatertrappen, kwel/wegzijgingsflux);

- indeling in landgebruik (gras, mais, overig landbouw, natuur, water en bebouwing);

- indeling in bodemtype (zand, klei, veen);

- indeling in chemische eigenschappen van de bodem (fosfaatbindend vermogen, mineralisatiecapaciteit, kationencapaciteit);

- indeling naar overige kenmerken (o.a. meteorologische kenmerken).

In figuur B1.1 is een overzicht gegeven van kaartlagen (kenmerken) die gebruikt zijn om tot een ruimtelijke verdeling te komen van de rekeneenheden (STONE-plots).

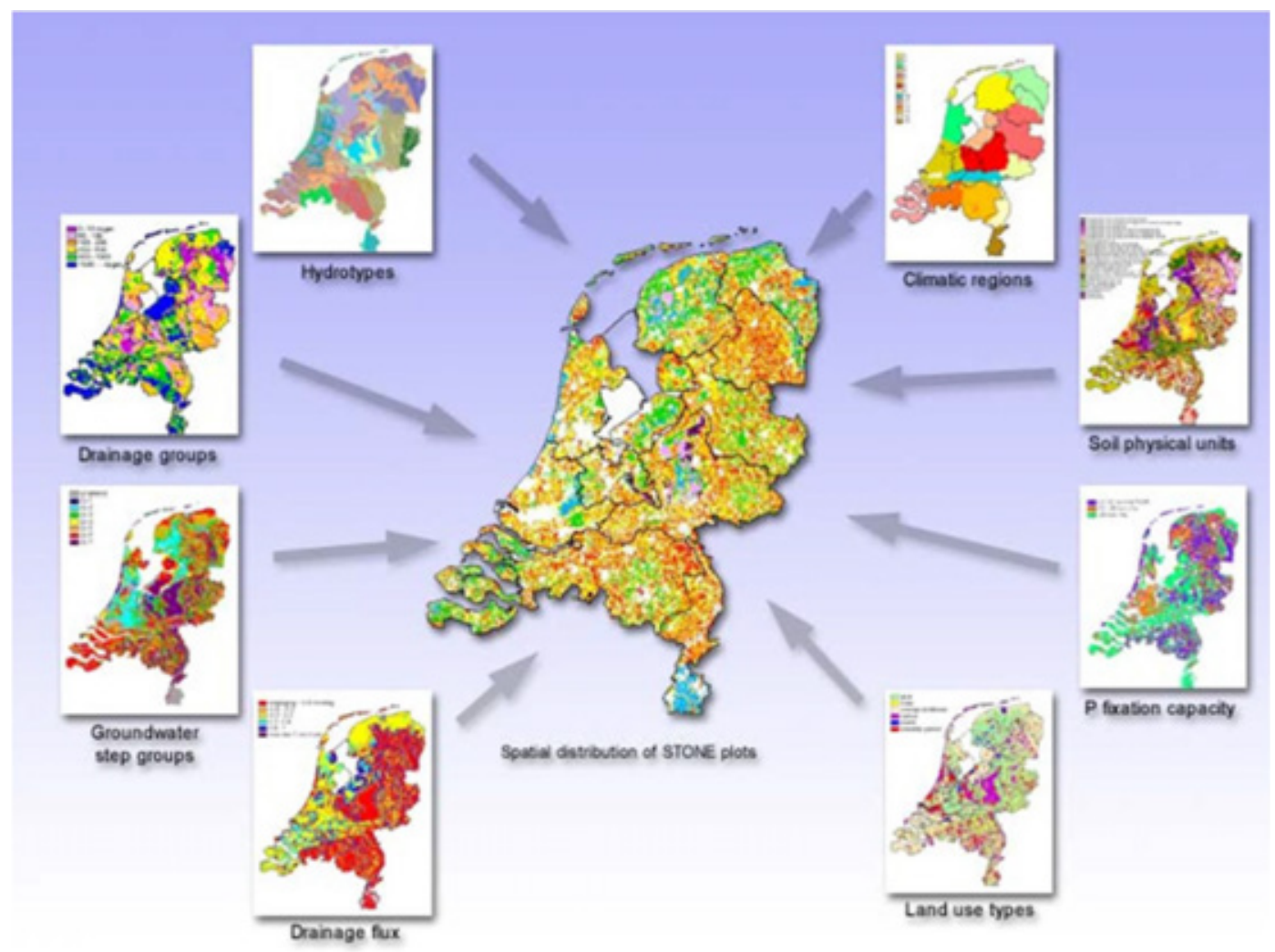

Figuur B1.1 Overzicht van de(belangrijkste) kaartlagen die gebruikt zijn voor de ruimtelijke verdeling van de STONE-plots. 
Omdat de huidige STONE-schematisering dateert uit 2000 en omdat het een landelijke schematisering betreft, is het mogelijk dat, indien STONE wordt ingezet voor een regionale studie, de schematisering in STONE onvoldoende overeenkomt met de regionale of lokale situatie van het betreffende studiegebied.

\section{Herschikkingsprocedure}

De herschikkingsprocedure is toegepast in verschillende regionale studies voor verschillende opdrachtgevers (Monitoring Stroomgebieden (Woestenburg en Van Tol-Leenders, 2011), HDSR (Van Boekel, 2013), Achtergrondbelasting HHNK (Van Boekel, 2015), Bronnenanalyse Wetterskip Fryslân (Van Boekel, 2016).

De herschikkingsprocedure bestaat uit verschillende onderdelen:

1. Gebiedsanalyse - vervaardigen nieuwe geclassificeerde kaarten - overlay van kaarten en afleiden van MLBG $^{5}$-combinaties

2. Afleiden nieuwe $\mathrm{N}$ - en $\mathrm{P}$-uitspoelingcijfers - selectie van representatieve STONE-plots die passen bij MLBG-combinaties

- Aggregeren van $\mathrm{N}$ - en P-belasting op ERC-niveau

- Neerschalen van $\mathrm{N}$ - en P-belasting naar het studiegebied (LSW-niveau)

3. Validatie (vergelijking met eerdere studies)

\section{Stap 1: Gebiedsanalyse}

Bij het genereren van de ruimtelijke verdeling van de STONE-plots worden verschillende kaartlagen gebruikt (figuur B.2):

De eerste stap in de herschikkingsprocedure is het genereren van een landsdekkende MLBG-kaart waarin een aantal kaartlagen is meegenomen:

- landgebruik

- bodemfysische eenheid

- Gt-klasse (hydrologische toestand)

- Meteodistrict

Landgebruik

Voor het huidige landgebruik wordt op dit moment gebruikgemaakt van het LGN7-bestand (Hazeu, 2014). Het LGN7-bestand onderscheidt 39 landgebruikstypen. Het is een grid-bestand met een ruimtelijke resolutie van $25 * 25 \mathrm{~m}$. Het bestand geeft een tijdsbeeld van het landgebruik voor 2012, dat voor zowel beleidsanalyses als voor modelinput is te gebruiken. In het bestand worden de belangrijkste landbouwgewassen, bos, water, natuur en stedelijke klassen onderscheiden.

De landgebruiksvormen in LGN7 komen niet een-op-een overeen met de landgebruiksvormen die in de STONE-schematisering worden onderscheiden, m.a.w. er is een vertaalslag nodig. De landgebruikstypen in LGN7 worden geclusterd tot zes landgebruiksvormen: grasland, akkerbouw, maïs, natuur, stedelijk gebied en open water, waarna een nieuwe LGN-kaart wordt vervaardigd met een resolutie van $25 \times 25 \mathrm{~m}$.

\section{Bodemtype}

Om inzicht te krijgen in de verschillen in bodemtype, is gebruikgemaakt van de 1:50.000-bodemkaart. In STONE komen twee indelingen voor de bodem voor: 1) volgens de PAWN-kaart en 2) volgens de CLEAN-kaart. In de huidige herschikkingsprocedure is er gekozen voor de PAWN-kaart.

Een veelgebruikte indeling voor het clusteren van de eenheden van de bodemkaart is de indeling naar bodemopbouw. Deze indeling wordt ook wel de PAWN-indeling genoemd (Wösten, 1988) en onderscheidt naar bodemopbouw $\mathbf{2 1}$ verschillende eenheden. In de huidige herschikkingsprocedure is er gekozen voor de PAWN-kaart. Ook hiervoor geldt dat de eenheden die in de bodemkaart worden

\footnotetext{
5 MLBG is een afkorting voor Meteo Landgebruik Bodemfysische eenheid en Grondwatertrap
} 
onderscheiden, opnieuw geclassificeerd/geclusterd moeten worden. Eindresultaat van stap $1 \mathrm{~b}$ is een nieuwe bodemkaart op basis met de PAWN-bodem met een resolutie van $25 \times 25 \mathrm{~m}$.

\section{Hydrologische toestand}

Naast het bodemtype wordt de 1:50.000-bodemkaart ook gebruikt om informatie te krijgen over de diepte en fluctuatie van het grondwater (Vries, 2003). In de bodemkaart worden deze weergegeven met 11 Gt-klassen (tabel B1.1). Eindresultaat van stap $1 \mathrm{c}$ is een nieuwe Gt-kaart met een resolutie van $25 \times 25 \mathrm{~m}$.

Tabel B1.1 Overzicht van grondwatertrappenindeling voor de Bodemkaart van Nederland 1:50.000.

\begin{tabular}{lll} 
Code grondwatertrap & $\begin{array}{l}\text { GHG } \\
(\mathrm{cm}-\mathrm{mv})\end{array}$ & $\begin{array}{l}\text { GLG } \\
(\mathrm{cm}-\mathrm{mv})\end{array}$ \\
I & - & $50-80$ \\
\hline II & - & $50-80$ \\
\hline II* & $25-40$ & $80-120$ \\
\hline III & $<40$ & $80-120$ \\
\hline III* & $25-40$ & $80-120$ \\
\hline IV & $>40$ & $>120$ \\
\hline V & $<40$ & $>120$ \\
\hline V* & $25-40$ & $>120$ \\
\hline VI & $40-80$ & $>120$ \\
\hline VII & $80-140$ & $>120$ \\
\hline VII* & $>140$ & \\
\hline
\end{tabular}

\section{Meteodistricten}

Naast landgebruik, bodemtype en Gt-klasse zijn de STONE-plots ook ruimtelijk ingedeeld in weerregio's. De indeling is tot stand gekomen door een directe toekenning van weerregio's aan PAWNdistricten. Er worden vijftien weerregio's onderscheiden.

\section{Stap 2: Genereren landsdekkende kaart met MLBG-eenheden}

In de eerste stap zijn nieuwe kaarten vervaardigd/verzameld met informatie over het landgebruik, bodemtype, hydrologische toestand (Gt-klasse) en meteoregio. In de tweede stap worden de verschillende kaarten gecombineerd, waardoor er zogenaamde MLBG-eenheden ontstaan met een resolutie van $25 \times 25 \mathrm{~m}$ (figuur B1.2).

Door de overlay van de verschillende kaartlagen ontstaan er MLBG-eenheden met unieke kenmerken. In tabel B1.2 zijn voorbeelden gegeven van een aantal eenheden en bijbehorende kenmerken.

Tabel B1.2 Aantal voorbeelden van (willekeurige) MLBG-eenheden.

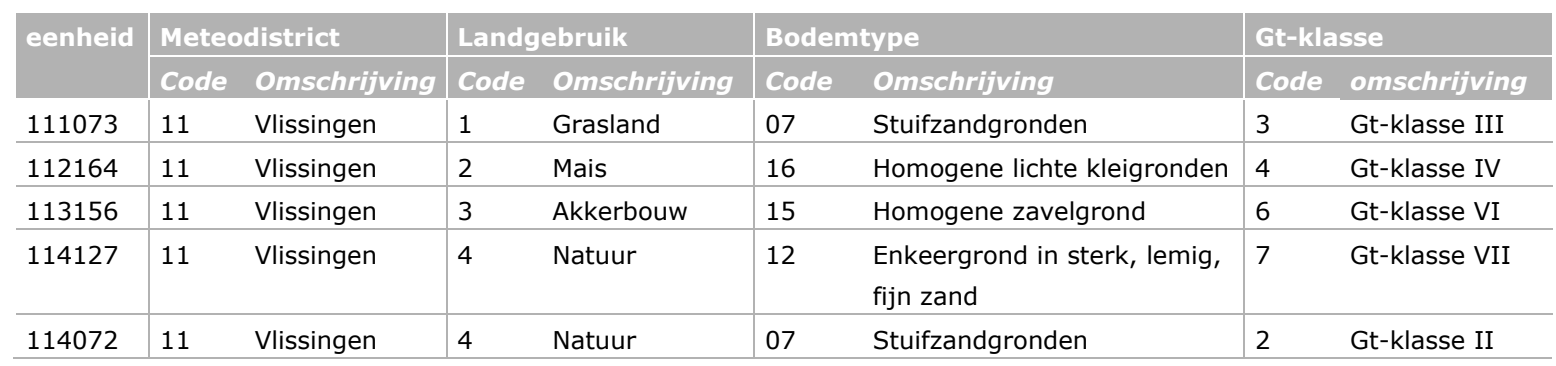

\section{Aandachtspunt}

Voor het genereren van de eenhedenkaart is een overlay gemaakt tussen de verschillende kaartlagen (LGN7, bodemkaart). Doordat de kaarten verschillende indelingen hanteren, is het mogelijk dat er een mismatch is tussen beide kaarten. In tabel B1.3 zijn een paar voorbeelden gegeven. Het meteodistrict is in dit voorbeeld weggelaten. 


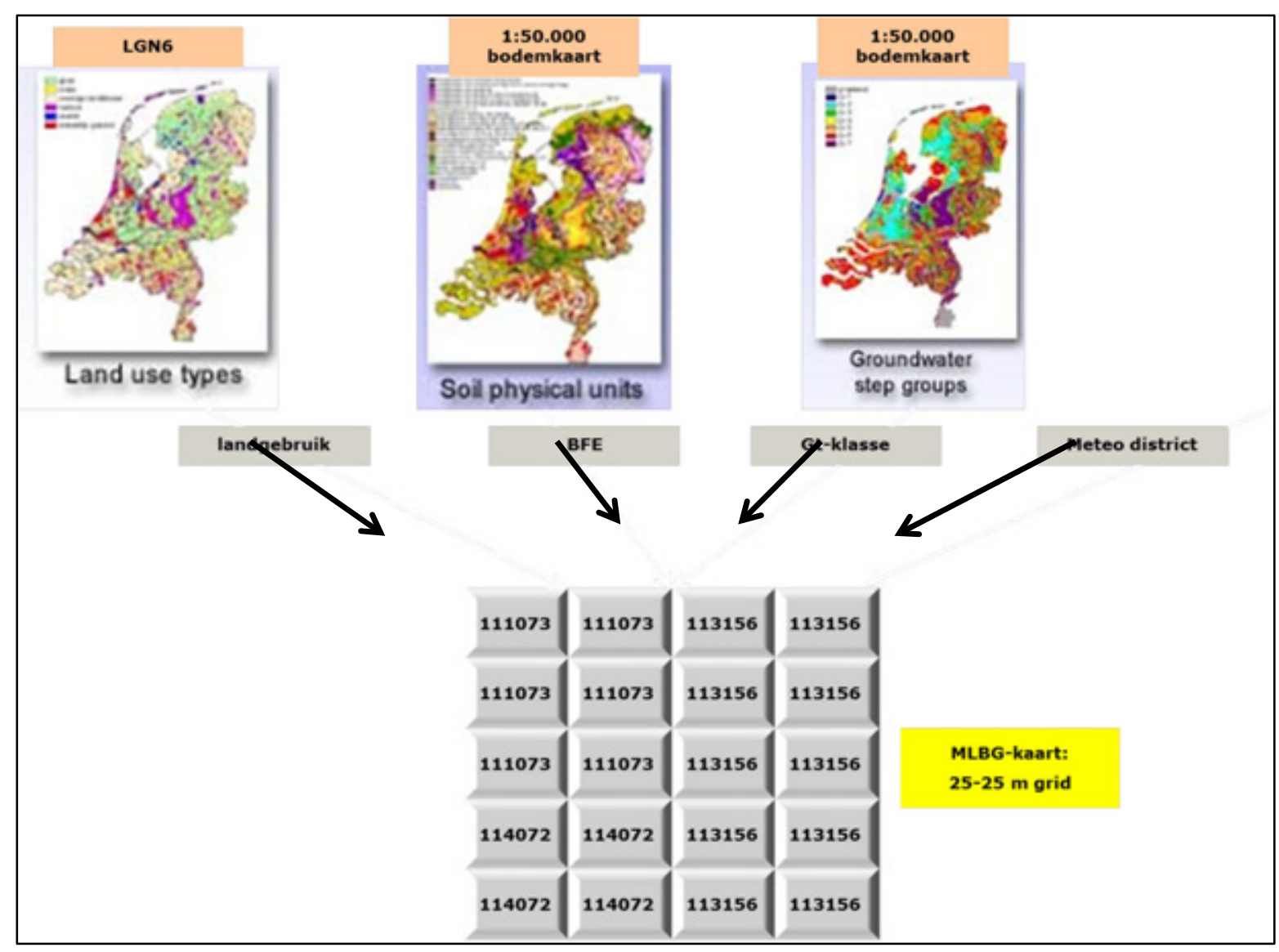

Figuur B1.2 Overzicht van de bestanden die gebruikt zijn bij het genereren van een kaart met MLBG-eenheden.

In bovenstaande voorbeelden is het landgebruik op basis van LNG7 grasland of natuur. Op basis van de 1:50.000-bodemkaart is dit echter open water en stedelijk gebied. Er wordt dan ook geen Gtklasse toegekend. Ook kan het voorkomen dat op basis van LGN7 aan een gebied 'open water' of 'stedelijk' gebied wordt toegekend, terwijl op basis van de 1:50.000-bodemkaart wel een bodemtype en Gt-klasse worden toegekend. Op voorhand is hierdoor al duidelijk dat er voor dit type MLBGeenheid geen representatieve STONE-plots gevonden kunnen worden.

In het script is een tussenstap voorzien waarin de MLBG-eenheden met een combinatie waarvoor sowieso geen STONE-plots gevonden kunnen, worden omgezet in een nieuwe eenheid. Hierbij is gekozen om het landgebruikstype op basis van LGN7 leidend te maken; met andere woorden: het landgebruik verandert niet.

Als op basis van LGN7 een gebied wordt geclassificeerd als 'open water' of als 'stedelijk gebied' worden er geen STONE-plots aan gekoppeld; het bodemtype en de Gt-klasse spelen dan geen rol. MLBG-eenheden die op basis van LGN7 geclassificeerd zijn als landbouw of natuur, in combinatie met bodemtype 22 (open water) en 23 (stedelijk gebied) en een ontbrekende Gt-klasse, worden 'omgezet' naar nieuwe eenheden op basis van de meest voorkomende MLBG-eenheden binnen een $E R C$ gebied/ECHO-gebied.

Tabel B1.3 Aantal voorbeelden van een mismatch tussen de LGN7-kaart en de 1: 50.000-bodemkaart.

\begin{tabular}{|c|c|c|c|c|c|c|}
\hline \multirow[t]{2}{*}{ MLBG-eenheid } & \multicolumn{2}{|c|}{ Landgebruik } & \multicolumn{2}{|r|}{ Bodemtype } & \multicolumn{2}{|c|}{ Gt-klasse } \\
\hline & Code & Omschrijving & Code & Omschrijving & Code & Omschrijving \\
\hline 1230 & 1 & Grasland & 22 & Water & 0 & - \\
\hline 5074 & 5 & Open water & 07 & Stuifzangronden & 4 & Gt-klasse IV \\
\hline 6156 & 6 & Stedelijk & 15 & Homogene zavelgrond & 6 & Gt-klasse VI \\
\hline
\end{tabular}


In tabel B1.4 is een (willekeurig) voorbeeld gegeven van de kenmerken van een ERC/ECHO-gebied. Het grootste gedeelte van het gebied bestaat uit akkerbouw, bodemfysische eenheid 15 (homogene zavelgronden) met een Gt-klasse IV.

Op basis van bovenstaande informatie worden de MLBG-eenheden met een mismatch 'omgezet' (tabel B1.5). De MLBG-eenheden 5074 en 6156 veranderen niet (landgebruik LNG7 is leidend). De MLBG-eenheden 1230 en 4220 worden omgezet naar nieuwe MLBG-eenheden met bodemfysische eenheid 15 en Gt-klasse 4.

Tabel B1.4 Overzicht van het landgebruik, bodemfysische eenheid en Gt-klasse binnen een ERC/ECHO-gebied.

\begin{tabular}{lll} 
Landgebruik & Omschrijving & Areaal (ha) \\
\hline 1 & Grasland & 174 \\
\hline 2 & Mais & 13 \\
\hline 3 & Akkerbouw & 1337 \\
\hline 4 & Natuur & 14 \\
\hline BFE & & 2 \\
\hline 07 & Stuifzandgronden & 1519 \\
\hline 15 & Homogene zavelgronden & 3 \\
\hline 18 & Kleigronden op veen & 11 \\
\hline 19 & Kleigronden op zand & 3 \\
\hline 23 & Stedelijk gebied & 3 \\
\hline Gt-klasse & & 32 \\
\hline 0 & Onbekend & 2 \\
\hline 2 & Gt-klasse II & 1441 \\
\hline 4 & Gt-klasse III & 3 \\
\hline
\end{tabular}

Tabel B1.5 'omzetting' van een oude MLBG-eenheid naar een nieuwe MLBG-eenheid op basis van de dominante gebiedskenmerken.

\begin{tabular}{ll} 
MLBG-eenheid oud & MLBG-eenheid nieuw \\
\hline 1230 & 1154 \\
\hline 4220 & 4154 \\
\hline 5074 & 5074 \\
\hline 6156 & 6156 \\
\hline
\end{tabular}

\section{Stap 3: afleiden $\mathbf{N}-/$ P-vrachten}

Nadat nieuwe MLBG-eenheden zijn bepaald, zijn representatieve STONE-plots gezocht voor het berekenen van de af- en uitspoeling naar grond- en oppervlaktewater. Hierbij kunnen de volgende situaties ontstaan:

1. Er worden meerdere representatieve STONE-plots per eenheid gevonden;

2. Er wordt één representatieve STONE-plot gevonden;

3. Er kunnen geen STONE-plots gevonden worden die voldoen aan de opgelegde criteria.

\section{Situatie 1}

Indien in de herschikking voor een MLBG-eenheid gekozen zou worden om één 'meest representatieve' STONE-plot te nemen, zou dit handmatig door een expert uitgevoerd moeten worden. Hierdoor zou de einduitkomst voor een deel afhankelijk zijn van de expert die de herschikking uitvoert. Dit verdient niet de voorkeur, omdat het problemen geeft bij het reproduceren van de resultaten en moeilijk qua argumentatie te verantwoorden is. Wanneer voor een MLBG-eenheid meerdere STONE-plots in aanmerking komen, wordt daarom in een geautomatiseerde selectieprocedure de STONE-plots geselecteerd die voldoen aan de betreffende MLBG-eenheid en hiervan wordt dan de gemiddelde af- en uitspoeling bepaald. Ook wordt voor de herkomst van de bronnen achter de af- en uitspoeling het 
gemiddelde van die STONE-plots genomen. Hiermee zal, ongeacht wie het script toepast, dit altijd tot dezelfde resultaten leiden.

In tabel B1.6 is een (willekeurig) voorbeeld gegeven voor MLBG-eenheid 111073 (meteodistrict 11, grasland op stuifzandgrond met Gt-klasse III). Er worden in totaal drie STONE-plots met deze combinatie gevonden.

Tabel B1.6 Gemiddelde stikstofbelasting van het oppervlaktewater voor de STONE-plots voor MLBGeenheid 111073.

\begin{tabular}{ll} 
STONE-plots & Stikstofuitspoeling $(\mathrm{kg} / \mathrm{ha})$ \\
1710 & 76,7 \\
\hline 1499 & 85,1 \\
\hline 1111 & 112,1 \\
\hline Gemiddeld & $\mathbf{9 1 , 3}$ \\
\hline
\end{tabular}

\section{Situatie 2}

Indien er één STONE-plot gevonden kan worden, worden de berekende af- en uitspoeling van deze plot toegekend aan een MLBG-eenheid.

\section{Situatie 3}

Indien er geen representatieve STONE-plots gevonden worden, omdat de gewenste combinatie landgebruik, bodemfysische eenheid en Gt-klasse binnen een meteodistrict niet voorkomt, is ervoor gekozen om stapsgewijs steeds meer informatie van de MLBG-eenheden los te laten net zolang alle eenheden zijn voorzien van een koppeling naar STONE plots. In tabel B1.7 is het stappenplan weergegeven voor toekenning van STONE-plots aan MLBG-eenheden.

Tabel B1.7 Overzicht van de stappen die doorlopen worden voor het afleiden van $N$ - en P-belasting opp. water per MLBG-eenheid.

\begin{tabular}{ll} 
Stappen & Omschrijving \\
Stap 0 & 1:1 match \\
\hline Stap 1 & Trapsgewijze aanpassing van bodemtypes met restricties \\
\hline Stap 2 & Trapsgewijze aanpassing van de Gt-klasse met restricties o.b.v. GHG (focus oppervlaktewater \\
\hline Stap 3 & Combinatie van stap $1+2$ \\
\hline Stap 4 & Aanpassing bodemfysische gegeven met beperkte restricties \\
\hline Stap 5 & Combinatie van stap $2+4$ \\
\hline Stap 6 & Geen restricties t.a.v. de Gt-klasse \\
\hline Stap 7 & Combinatie van stap $1+6$ \\
\hline Stap 8 & Combinatie van stap 4 6 \\
\hline Stap 9 & Geen restricties t.a.v. Gt-klasse en bodemfysische eenheid \\
\hline
\end{tabular}

Hieronder worden de stappen 1, 2 en 4 nader toegelicht. De overige stappen zijn combinaties van voorgaande stappen ( $\operatorname{stap} 3,5,7$ en 8 ) of liggen voor de hand (stap 6 en 9).

Stap 1: aanpassing bodemfysische eenheden met restrictie

De eerste stap is een trapsgewijze aanpassing van bodemtypes met restrictie. Er worden in totaal 21 relevante bodemtypen onderscheiden (nr. 22 en 23 is respectievelijk open water en stedelijk gebied). In tabel B1.8 is een overzicht gegeven van mogelijke uitwisselingen. Voor een aantal bodemfysische eenheden (BFE) is het niet mogelijk om een andere BFE te selecteren, de andere BFE's kunnen met een of meerdere BFE's uitgewisseld worden. Indien er sprake is van meerdere opties is een trapsgewijze aanpassing voorzien (opgelegde volgorde). 
Tabel B1.8 Overzicht van de mogelijke 'uitwisseling' tussen de verschillende bodemfysische eenheden.

\begin{tabular}{lll} 
Groep & Grondsoort & Bodemfysische eenheden \\
\hline 1 & Veen & 1,3 \\
\hline 2 & Veen & $2,4,5$ \\
\hline 4 & Veen & 6 \\
\hline 5 & Zand & $7,8,9,12,13$ \\
\hline 6 & Zand & 10,14 \\
\hline 8 & Zand & 11 \\
\hline 9 & Klei & $15,16,19$ \\
\hline 10 & Klei & 17,18 \\
\hline & Klei & 20 \\
\hline
\end{tabular}

Stap 2: aanpassing Gt-klasse

De twee stap is een trapsgewijze aanpassing van Gt-klasse met restricties op basis van de gemiddelde hoogste grondwaterstand (GHG). Een randvoorwaarde voor het selecteren van STONE-plots met een andere Gt-klasse is dat deze in hetzelfde cluster valt.

De grondwatertrappen zijn op basis van de GHG geclusterd in drie groepen:

- nat: Gt-klasse I, II, III en V

- matig droog: Gt-klasse IV en VI

- droog: Gt-klasse VII en VIII

Ook hierbij geldt dat er een voorkeursvolgorde is vastgelegd.

Stap 4: aanpassing bodemfysische eenheden met beperkte restrictie

In de eerste stap is een aanpassing van de bodemfysische eenheden voorzien waarbij 10 groepen onderscheiden worden. In stap 4 wordt een aantal groepen geclusterd op basis van de grondsoort (tabel B1.9).

Tabel B1.9 Overzicht van de mogelijke 'uitwisseling' tussen de verschillende bodemfysische eenheden op basis van de grondsoort.

\begin{tabular}{lll} 
Groep & Grondsoort & Bodemfysische eenheden \\
\hline 1 & Veen & $1 \mathrm{t} / \mathrm{m} 6$ \\
\hline 2 & Zand & $7 \mathrm{t} / \mathrm{m} 14$ \\
\hline 3 & Klei & $15 \mathrm{t} / \mathrm{m} \mathrm{20}$ \\
\hline
\end{tabular}

Nadat alle 9 stappen zijn doorlopen, is het mogelijk om voor iedere MLBG-eenheid (rekeneenheid) een stikstof- of fosforbelasting toe te kennen (zie voorbeeld in figuur B1.3).

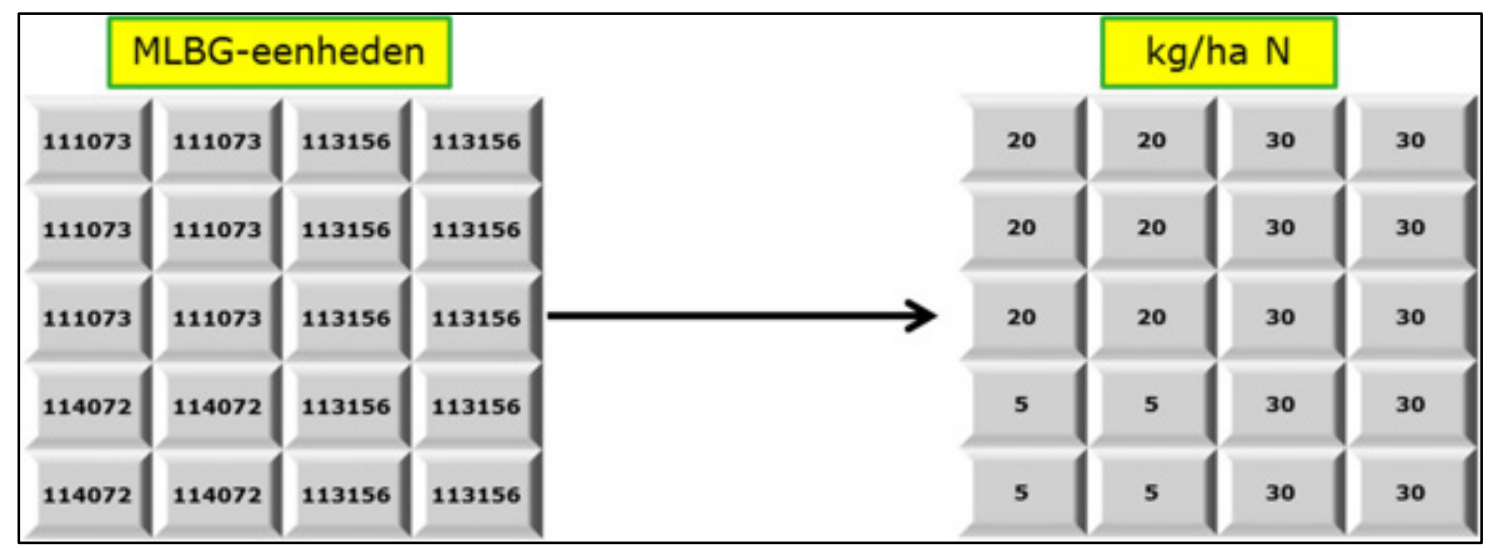

Figuur B1.3 Voorbeeld van de stikstofbelasting per MLBG-eenheid per rekeneenheid. 


\section{Bijlage 2 Bronnen in de \\ EmissieRegistratie}

Tabel B2.1 Indeling van de bronnen in de EmissieRegistratie aan de doelgroep, subdoelgroep en de indeling die in de ECHO-methodiek wordt gehanteerd.

\begin{tabular}{|c|c|c|c|}
\hline Subdoelgroep & & $\begin{array}{l}\text { bijdrage } N \\
\text { of } P\end{array}$ & ECHO-indeling \\
\hline \multirow{5}{*}{ Landbouw } & Glastuinbouw afvalwater & $>1 \%$ & \multirow{4}{*}{ LO } \\
\hline & Landbouwbedrijven (o.a. erfafspoeling) & $>1 \%$ & \\
\hline & Meemesten sloten & $0,1-1 \%$ & \\
\hline & $\begin{array}{l}\text { Productgebruik landbouw (NMI3 emissies vanuit } \\
\text { kassen) }\end{array}$ & 0 (geen) & \\
\hline & $\begin{array}{l}\text { Af- en uitspoeling landelijk gebied (landbouw + } \\
\text { natuur) }\end{array}$ & $>1 \%$ & UA \\
\hline \multirow{9}{*}{ Overige industrie } & Basismetaal & $0,1-1 \%$ & \multirow{17}{*}{ IND } \\
\hline & Bouwmaterialen industrie & $<0,1 \%$ & \\
\hline & Grafische industrie & 0 (geen) & \\
\hline & Industrie overig & 0 (geen) & \\
\hline & Metaalelektro & $<0,1 \%$ & \\
\hline & Papier(waren) & $0,1-1 \%$ & \\
\hline & Rubber- en kunststofverwerkende industrie & $<0,1 \%$ & \\
\hline & Textiel- en tapijtindustrie & 0 (geen) & \\
\hline & Voedings- en genotmiddelenindustrie & $>1 \%$ & \\
\hline \multirow{4}{*}{ Chemische industrie } & Chemische industrie basisproducten & $0,1-1 \%$ & \\
\hline & Chemische industrie bestrijdingsmiddelen & $<0,1 \%$ & \\
\hline & Chemische industrie kunstmeststoffen & $0,1-1 \%$ & \\
\hline & Chemische industrie overig & $0,1-1 \%$ & \\
\hline Raffinaderijen & Raffinage en verwerking & $0,1-1 \%$ & \\
\hline \multirow{3}{*}{ Energiesector } & Olie-/gaswinning land & 0 (geen) & \\
\hline & Opwekking elektriciteit & $0,1-1 \%$ & \\
\hline & Transport en distributie olie en gas & 0 (geen) & \\
\hline Verkeer en Vervoer & Binnenscheepvaart & $0,1-1 \%$ & \multirow{9}{*}{ ov } \\
\hline Consumenten & Huishoudelijk afvalwater & $0,1-1 \%$ & \\
\hline Bouw & Overige bouw & 0 (geen) & \\
\hline \multirow{3}{*}{ Afvalverwijdering } & AVI's & $0,1-1 \%$ & \\
\hline & Overige afvalbedrijven & $<0,1 \%$ & \\
\hline & Storten & $<0,1 \%$ & \\
\hline Drinkwatervoorziening & Overig drinkwater & 0 (geen) & \\
\hline \multirow{3}{*}{$\begin{array}{l}\text { Riolering en } \\
\text { waterzuiveringsinstallaties }\end{array}$} & Energiegebruik en processen & $<0,1 \%$ & \\
\hline & $\begin{array}{l}\text { Ongezuiverd rioolwater (regenwaterriolen + } \\
\text { overstorten) }\end{array}$ & $0,1-1 \%$ & \\
\hline & Effluenten lozingen & $>1 \%$ & $\mathrm{EF}$ \\
\hline $\begin{array}{l}\text { Handel, Diensten en } \\
\text { Overheid }\end{array}$ & Energiegebruik en processen handel & $<0,1 \%$ & ov \\
\hline Overig & Atmosferische depositie (open water) & $>1 \%$ & DW \\
\hline
\end{tabular}




\section{Bijlage 3 Betrouwbaarheid bronnen in de EmissieRegistratie}

In onderstaande tabel is voor een aantal bronnen uit de EmissieRegistratie een betrouwbaarheidspercentage (\%) weergegeven (bron: www.emissieregistratie.nl). De volgende betrouwbaarheidspercentages worden gehanteerd: $1 \%, 5 \%, 10 \%, 25 \%, 50 \%, 100 \%, 200 \%$ en $400 \%$. Een betrouwbaarheid van $1 \%$ wil zeggen dat het desbetreffende onderdeel zeer betrouwbaar is; een betrouwbaarheid van $400 \%$ betekent een grote onzekerheid in het desbetreffende onderdeel (voor verder toelichting zie www.emissieregistratie.nl).

Tabel B3.1 Betrouwbaarheid (\%) van een aantal bronnen uit de EmissieRegistratie voor verschillende doelgroepen/subdoelgroepen.

\begin{tabular}{|c|c|c|c|c|c|c|}
\hline \multirow[t]{2}{*}{ Bron } & \multicolumn{6}{|c|}{ Betrouwbaarheid } \\
\hline & Vracht $^{1}$ & $E V V^{1}$ & $E F^{2}$ & $V C^{3}$ & Riool $^{4}$ & $\operatorname{Reg}^{5}$ \\
\hline Glastuinbouw afvalwater & - & 5 & $25-50$ & 25 & 10 & 100 \\
\hline Erfafspoeling & - & 50 & 50 & 25 & - & 25 \\
\hline Landbouwbedrijven & $50-200$ & - & - & 1 & 10 & $1-5$ \\
\hline Meemesten sloten & - & 10 & 100 & 1 & - & 100 \\
\hline Overige industrie ${ }^{7}$ & $50-200$ & 5 & 25 & 1 & 10 & $1-10$ \\
\hline Chemische industrie $^{7}$ & $50-200$ & 5 & 25 & 1 & 10 & $1-10$ \\
\hline Raffinaderijen & $50-200$ & - & - & 1 & 10 & $1-5$ \\
\hline Energiesector & $50-200$ & - & - & 1 & 10 & $1-5$ \\
\hline Binnenscheepvaart & - & 10 & 25 & 50 & - & 50 \\
\hline Huishoudelijk afvalwater & - & 1 & 25 & - & $10-100$ & 10 \\
\hline Bouw & $50-200$ & - & - & 1 & 10 & $1-5$ \\
\hline Afvalverwijdering ${ }^{7}$ & $50-200$ & 5 & 25 & 1 & 10 & $1-10$ \\
\hline Drinkwatervoorziening & $50-200$ & - & - & 1 & 10 & $1-5$ \\
\hline Energiegebruik en processen riolering en rwzi's & $50-200$ & - & - & 1 & 10 & $1-5$ \\
\hline Regenwaterriolen & 10 & - & - & - & 25 & 200 \\
\hline Overstorten & 10 & - & - & - & 50 & 200 \\
\hline IBA en niet aangesloten huishoudens & 10 & - & - & - & 100 & 200 \\
\hline Effluenten lozingen & 5 & n.v.t. & n.v.t. & 1 & 1 & 1 \\
\hline Handel, Diensten en Overheid & $50-200$ & - & - & 1 & 10 & $1-5$ \\
\hline Atmosferische depositie & 25 & - & - & $5-200$ & 10 & 50 \\
\hline
\end{tabular}

1. Vracht: Berekening jaarvrachten

2. EVV: Emissie-verklarende variabelen

3. EF: Emissiefactor

4. VC: Verdeling compartimenten

5. Riool: Emissieroutes via riool naar water

6. Reg: Regionalisatie

7. betrouwbaarheid afgeleid uit meerdere factsheets 


\section{Bijlage 4 Retentie}

De retentie van stikstof en fosfor in het oppervlaktewater varieert per polder en is afhankelijk van de onderliggende retentieprocessen. De grootte van deze retentieprocessen is afgeleid uit metingen in het oppervlaktewater (PLONS). Op deze manier is de capaciteit van het oppervlaktewatersysteem bepaald om stikstof vast te leggen of te verwijderen, uitgedrukt in gram per $\mathrm{m}^{2}$ waterbodem. De zo berekende absolute $\mathrm{N}$-retentie heeft betrekking op alle nutriëntenbronnen in de polder. De volgende retentieprocessen zijn gekwantificeerd:

- Denitrificatie

- Netto-opname (zomerhalfjaar) en -afgifte (winterhalfjaar) van nutriënten door waterplanten

Dit is gedaan voor polders die vooral uit veen of klei bestaan. Voor zandpolders (Noord-Nederland) waren onvoldoende metingen beschikbaar om de retentieprocessen te kwantificeren. Het retentieproces sedimentatie is niet expliciet meegenomen, al zit dit proces deels verwerkt in de waterplantensterfte die een groot aandeel heeft in de totale sedimentatie.

\section{Retentie van stikstof in polders door denitrificatie}

Voor het PLONS-project (www.plons.wur.nl) is in een aantal sloten verspreid over Nederland de denitrificatie gemeten. De gemeten denitrificatiesnelheden in poldersloten en de watertemperatuur tijdens het meten, ingedeeld naar het bodemtype klei of veen, zijn weergegeven in tabel B4.1.

Tabel B4.1 Gemeten denitrificatiesnelheden in veen- en kleigebieden en de watertemperatuur op het moment van meten (Veraart, in voorbereiding); $n=$ aantal waarnemingen, std=standaarddeviatie.

\begin{tabular}{|c|c|c|c|c|c|c|}
\hline \multirow[b]{2}{*}{ bodemtype } & \multirow[b]{2}{*}{ n } & \multirow{2}{*}{$\begin{array}{c}\text { Denitrificatie } \\
\left(\mu \mathrm{mol} \mathrm{N} \mathrm{m}^{-2} \mathbf{h}^{-1}\right) \\
\text { gemiddeld }\end{array}$} & \multirow{2}{*}{$\begin{array}{c}\begin{array}{c}\text { Denitrificatie } \\
\left(\mu \mathrm{mol} \mathbf{N ~ m}^{-2} \mathbf{h}^{-1}\right)\end{array} \\
\text { minimum }\end{array}$} & \multirow{2}{*}{$\begin{array}{c}\begin{array}{c}\text { Denitrificatie } \\
\left(\mu \mathrm{mol} \mathrm{N} \mathrm{m}^{-2} \mathrm{~h}^{-1}\right)\end{array} \\
\text { maximum }\end{array}$} & \multicolumn{2}{|c|}{$\begin{array}{c}\text { Temperatuur } \\
\left({ }^{\circ} \mathrm{C}\right) \\
\end{array}$} \\
\hline & & & & & gemiddeld & Std \\
\hline veen & 7 & 62,9 & 5,9 & 166,6 & 21,3 & 0,8 \\
\hline
\end{tabular}

Deze denitrificatiesnelheden zijn omgezet naar een gemiddelde denitrificatiesnelheid in het zomer- en het winterhalfjaar door aan te nemen dat de denitrificatiesnelheid $(D)$ afhangt van de watertemperatuur $(T)$ volgens een aangepaste Arrhenius-vergelijking:

$$
D_{T}=D_{20} \cdot \theta_{S}^{(T-20)}
$$

Waarin $D_{20}$ de denitrificatiesnelheid is bij $20^{\circ} \mathrm{C}$ en $\theta_{s}$ de temperatuurcoëfficiënt die de waarde 1,07 is toegekend; een waarde die kenmerkend is voor veel biochemische reacties. Echter zijn voor de denitrificatie ook hogere waarden voor de temperatuurcoëfficiënt gevonden: van 1,24 en 1,28 (Veraart, 2011b). Met formule 1 zijn maandgemiddelde denitrificatiesnelheden berekend voor de kleien veenpolders, uitgaande van maandgemiddelde luchttemperaturen gemeten in de Bilt in de jaren 1990-2009. De maandgemiddelde denitrificatiesnelheden zijn opgeschaald naar zomer- en winterhalfjaargemiddelden (tabel B4.2).

Tabel B4.2 Afgeleide denitrificatiesnelheden voor klei- en veenpolders in het winter- en zomerhalfjaar.

\begin{tabular}{|c|c|c|}
\hline \multirow[b]{2}{*}{ Bodemtype } & \multicolumn{2}{|c|}{ Denitrificatie $\left(\mathrm{g} \mathrm{N} \mathrm{m}^{-2}\right)$} \\
\hline & zomerhalfjaar & winterhalfjaar \\
\hline klei & 9,9 & 5,3 \\
\hline
\end{tabular}




\section{Retentie van stikstof door groei van waterplanten}

Uit verschillende databronnen is een inschatting gemaakt van de hoeveelheid waterplanten aan het einde van het groeiseizoen, gemiddeld over de klei- en veenpolders (tabel B4.3). Om een inschatting te kunnen maken van de stikstof die gemoeid is met de groei en sterfte van waterplanten, is geschat welk deel van de biomassa 'overwintert'. Modelresultaten van het oppervlaktewaterkwaliteitsmodel NuswaLite (Siderius, 2008) geven aan dat ongeveer $20 \%$ van de kroosbiomassa overwintert en ongeveer $25 \%$ van de waterpest en ondergedoken waterplanten overwintert.

Tabel B4.3 Gemiddelde hoeveelheid waterplanten aan het einde van het groeiseizoen, volgend uit verschillende databronnen.

\begin{tabular}{lcll} 
& & \multicolumn{2}{l}{ Waterplanten $\left(\mathrm{g}\right.$ droge stof $\left.\mathrm{m}^{-2}\right)$} \\
bodemtype & waterpest & kroos & ondergedoken \\
klei & 8 & 43 & 12 \\
\hline veen & 29 & 14 & 25 \\
\hline
\end{tabular}

Tabel B4.4 geeft een overzicht van de geschatte hoeveelheid stikstof die gemoeid is met de groei en sterfte van waterplanten, aangenomen dat:

- kroosbiomassa voor $4 \%$ uit $\mathrm{N}$ bestaat (Roijackers, 2004);

- ondergedoken waterplanten en waterpest voor 3,5\% uit N bestaan (Muhammetoglu, 2000);

- de waterlopen aan het einde van de zomer worden gemaaid, waardoor $80 \%$ van de waterplanten wordt verwijderd. De overgebleven $20 \%$ draagt bij aan de nalevering van $\mathrm{N}$ naar de waterkolom door sterfte.

Tabel B4.4 Hoeveelheid $N$ die naar schatting is gemoeid met de nettogroei (zomerhalfjaar) en nettosterfte (winterhalfjaar) van waterplanten in klei- en veenpolders. NB Aangenomen is dat $80 \%$ van de waterplanten in de waterlopen aan het einde van de zomer wordt gemaaid; deze planten sterven niet meer af in de waterlopen, waardoor alleen de resterende $20 \%$ van de waterplanten bijdraagt aan de nalevering van $N$ door sterfte.

\begin{tabular}{|c|c|c|}
\hline bodemtype & $\begin{array}{c}\text { groei } \\
\left(\mathrm{g} \mathrm{N} \mathrm{m}^{-2}\right)\end{array}$ & 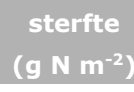 \\
\hline klei & 1,92 & 0,38 \\
\hline
\end{tabular}

\section{Totale stikstofretentie in poldersystemen}

Tabel B4.5 geeft de geschatte hoeveelheid stikstofretentie in de klei- en veenpolders; het opgetelde effect van denitrificatie en waterplanten. Deze hoeveelheden, in gram per $\mathrm{m}^{2}$ waterbodem, zijn vertaald naar hoeveelheden per polder door vermenigvuldiging met het areaal aan open water volgens het NHI (www.nhi.nu). Het is de vraag of het openwateroppervlak een goede benadering geeft van het oppervlak waarover stikstofretentie plaatsvindt.

De gehele natte omtrek - waterbodem en talud - draagt waarschijnlijk bij aan de stikstofretentie, al zal het talud per strekkende meter waarschijnlijk in mindere mate bijdragen. Daarom is het openwateroppervlak bij benadering een goede maat voor het effectieve retentieoppervlak.

Tabel B4.5 Geschatte hoeveelheid stikstofretentie in klei- en veenpolders.

\begin{tabular}{|c|c|c|}
\hline bodemtype & $\begin{array}{l}\text { zomerhalfjaar } \\
\qquad\left(\mathrm{g} \mathrm{N} \mathrm{m}^{-2}\right)\end{array}$ & $\begin{array}{l}\text { winterhalfjaar } \\
\qquad\left(\mathrm{g} \mathrm{N} \mathrm{m} \mathrm{m}^{-2}\right)\end{array}$ \\
\hline klei & 11,8 & 5,0 \\
\hline
\end{tabular}


Vanwege deze eerste ordebenadering voor de stikstofdynamiek kan naar analogie van de methodiek voor de vrij afwaterende gebieden ook hier een retentie optreden die de $100 \%$ overschrijdt. Derhalve wordt een limitering toegepast van maximaal $90 \%$ retentie op de inkomende stikstofvracht.

Retentie van fosfor in poldersystemen

Voor fosfor is het niet mogelijk gebleken om relaties af te leiden op basis van het areaal waterbodem. Op basis van diverse studies wordt voor fosfor in poldersystemen een retentie van $20 \%$ aangenomen voor puntbronnen en van $50 \%$ voor diffuse bronnen.

\section{Retentie in vrij afwaterende gebieden}

In de relevante literatuur voor vrij afwaterende gebieden wordt vaak een verband gelegd tussen de retentie voor N en P en de 'specifieke afvoer' (o.a. Klein, 2011; Seitzinger, 2002). De 'specifieke afvoer' is gedefinieerd als de afvoer bij het uitstroompunt van het stroomgebied, gedeeld door het bovenstroomse wateroppervlak (zie Vergelijking 2).

De eerder in Van Boekel (2011) gebruikte relaties gingen uit van 'hydraulische verblijftijd', die van de 'specifieke afvoer' verschilt door in plaats van wateroppervlak het bovenstroomse watervolume in de noemer mee te nemen. Het verschil tussen wateroppervlak en watervolume is de waterdiepte, die in vrij afwaterende stroomgebieden erg variabel is in zowel tijd als ruimte. De hypothese is dat vanwege deze variabiliteit de retentie van $\mathrm{N}$ en $\mathrm{P}$ voor de grotere (deel)stroomgebieden minder goed is te relateren aan de 'hydraulische verblijftijd'. Daar komt bovendien nog bij dat de waterdiepte aanzienlijk slechter karteerbaar is dan het wateroppervlak.

$$
Q_{\text {specifiek }}=\frac{Q_{\text {afvoerpunt }}}{A_{\text {water }}}
$$

waarin:

$\mathrm{Q}_{\text {specifiek }}=$ specifieke afvoer $\left(\mathrm{m}^{3} \mathrm{~s}^{-1} \mathrm{ha}^{-1}\right)$

$\mathrm{Q}_{\text {afvoer }}=$ afvoer bij uitstroompunt stroomgebied $\left(\mathrm{m}^{3} \mathrm{~s}-1\right)$

$\mathrm{A}_{\text {water }}=$ open wateroppervlak in het deelstroomgebied (ha)

Voor deze studie zijn deze verbanden bepaald voor een aantal vrij afwaterende stroomgebieden. De hiervoor geselecteerde stroomgebieden voldoen aan de volgende criteria:

- De uitspoeling van nutriënten vanuit het landsysteem is verreweg de belangrijkste nutriëntenbron voor het oppervlaktewater.

- Het stroomgebied is niet aangesloten op bovenstrooms gelegen stroomgebieden.

- De uitgaande nutriëntenvracht bij het uitstroompunt moet goed te bepalen zijn op basis van metingen.

Het eerste criterium is van belang, omdat de af te leiden retentie alleen betrekking heeft op de diffuse nutriëntenuitspoeling vanuit het landsysteem. Het tweede criterium is hieraan gerelateerd en eveneens bedoeld om onbekende overige bronnen te elimineren. Uiteindelijk bleken er vier vrij afwaterende stroomgebieden te voldoen aan bovenstaande criteria:

- Drentsche Aa

- Schuitenbeek

- Hoevelakense, Barneveldse en Esvelderbeek (HBE-beek)

- Wapserveensche en Vledder Aa (WV Aa)

De Drentsche Aa en de Schuitenbeek zijn intensief bemeten in het project Monitoring Stroomgebieden (Roelsma, 2011; Roelsma, 2011b) en voor de overige twee stroomgebieden zijn in het kader van het ex ante KRW-project meetdata aangeleverd. De nutriëntenretentie $\left(R_{a}\right)$ is per gebied als volgt bepaald:

$$
R_{a}=L_{\text {uitspoeling }}-L^{*} \text { uitstroom }
$$

waarin:

$\mathrm{R}_{\mathrm{a}} \quad=$ absolute nutriëntenretentie in het oppervlaktewater $(\mathrm{g})$

$\mathrm{L}_{\text {uitspoeling }}=$ uitspoeling van nutriënten vanuit het landsysteem $(\mathrm{g})$

$\mathrm{L}^{*}$ uitstroom $=$ uitstromende nutriënten bij uitstroompunt, gecorrigeerd voor andere bronnen dan de nutriëntenuitspoeling $(\mathrm{g})$ 
De nutriëntenuitspoeling vanuit het landsysteem (Luitspoeling) is voor de Drentsche Aa en Schuitenbeek bepaald op basis van een gekalibreerd SWAP-ANIMO modelinstrumentarium (Siderius, 2011). Voor de andere twee stroomgebieden is hiervoor het model STONE, versie 2.4, gebruikt (Wolf, 2003).

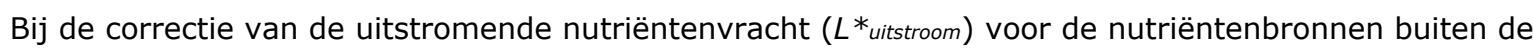
uitspoeling (zoals rwzi's en industriële lozingen) is rekening gehouden met de retentie die aangrijpt op deze nutriëntenbronnen (volgens de EmissieRegistratie), zoals eerder bepaald in Van Boekel (2011). Tabel B4.6 geeft aan welke data per stroomgebied zijn gebruikt om de uitstromende nutriëntenvracht te bepalen.

De uitstromende nutriëntenvracht is per dag bepaald. Hiervoor zijn dagelijkse nutriëntenconcentraties nodig die zijn verkregen door lineair te interpoleren tussen de gemeten concentraties met maandelijkse steekmonsters (in HBE-beek en WV Aa). Ook is lineaire interpolatie gebruikt om ontbrekende debietdata en ontbrekende debietsproportionele gemeten nutriëntenconcentraties aan te vullen.

Tabel B4.6 Data per stroomgebied ter bepaling van de uitgaande nutriëntenvracht (=debiet * concentratie) bij het uitstroompunt

\begin{tabular}{lccccc} 
& \multicolumn{3}{c}{ debiet } & nutriëntenconcentraties \\
\cline { 2 - 6 } Drentsche Aa & $*$ & Dagelijks & 1114 & Wekelijks & debietsproportioneel \\
\hline Schuitenbeek & 25210 & Dagelijks/elk uur & 25210 & Wekelijks & debietsproportioneel \\
\hline HBE-beek & 4070 & Dagelijks & 29738 & Maandelijks & Steekmonster \\
\hline WV Aa & Stuw Wulpen & dagelijks & 1STEA8RO & maandelijks & steekmonster \\
\hline
\end{tabular}

* op basis van modelresultaten van het hydraulische model SWQN (Smit, 2009).

\section{Verband tussen retentie en specifieke afvoer}

De retentiefractie $(R f)$, het deel van de totale nutriëntenbelasting dat in het stroomgebied wordt vastgelegd, kan als volgt worden gerelateerd aan de 'specifieke afvoer' Qspecifiek (Klein, 2011; Seitzinger, 2002):

$$
R_{f}=a \cdot Q_{\text {specifiek }}^{b}
$$

waarbij $a$ en $b$ nader te bepalen coëfficiënten zijn.

Voor de vier stroomgebieden zijn deze coëfficiënten bepaald voor het winter- en het zomerhalfjaar, omdat dit de temporele resolutie is van zowel het KRW-Echo-model als de KRW-Verkenner. In elk stroomgebied zijn voor elk zomer- en winterhalfjaar met voldoende meetdata de retentie en de 'specifieke afvoer' bepaald, wat resulteert in de puntenwolken in figuur B4.1. De 'specifieke afvoer' is hierbij berekend met het gemeten uitgaande debiet en met het openwateroppervlak op basis van de TOP10 waterlopen, waarvan de geometrie is afgeleid van het hydrotype waarin de waterlopen liggen (Massop, 2007).

De puntenwolken in figuur B4.1 zijn gefit met Vergelijking 3, wat resulteert in waarden voor de coëfficiënten $a$ en $b$ (tabel B4.7). Te zien is dat de fit in alle gevallen matig is. Dit suggereert dat de 'specifieke afvoer' niet de enige verklarende variabele is voor de retentie, uitgaande van juiste metingen en modeldata. Het gevonden verband voor $\mathrm{N}$ is in figuur B4.2 vergeleken met verbanden afgeleid in andere studies (Klein, 2011; Venohr, 2005; Seitzinger, 2002), waaraan overigens wel andere temporele en ruimtelijke schaalniveaus ten grondslag liggen.

Een bekend nadeel van de machtsbenadering (Vergelijking 3) is dat de retentiefractie groter dan 1 kan worden bij kleine waarden voor de 'specifieke afvoer'. In deze gevallen is de retentiefractie afgekapt tot $90 \%$ van de inkomende vracht, omdat grotere retentiewaarden onrealistisch worden geacht. 


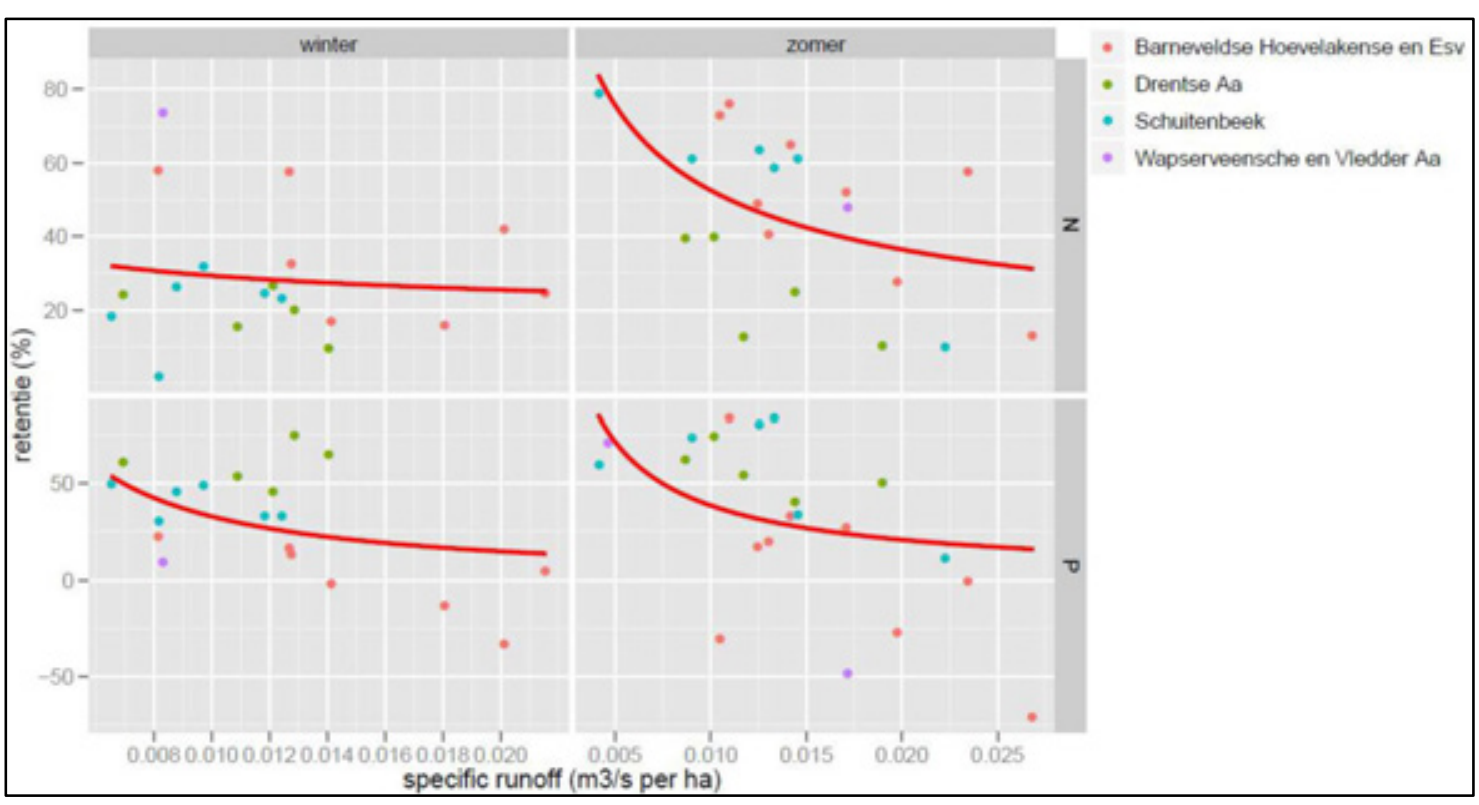

Figuur B4.1 Verband tussen het retentiepercentage (op de uitspoelende nutriënten vanuit het landsysteem) en de 'specifieke afvoer' voor de vier stroomgebieden, per stof en per halfjaar. De rode lijn geeft de gefitte curve (Vergelijking 4).

Tabel B4.7 Gevonden coëfficiënten voor de vier stroomgebieden op basis van 'specifieke afvoer' in $\mathrm{m}^{3} \mathrm{~s}^{-1} h \mathrm{a}^{-1}$.

\begin{tabular}{lccccc} 
& \multicolumn{3}{c}{ Stikstof } & & Fosfor \\
\cline { 2 - 6 } Winterhalfjaar & $\mathrm{a}$ & $\mathrm{b}$ & $\mathrm{a}$ & b \\
\hline zomerhalfjaar & 0.1153 & -0.2025 & 0.0017 & -1.1449 \\
\hline
\end{tabular}

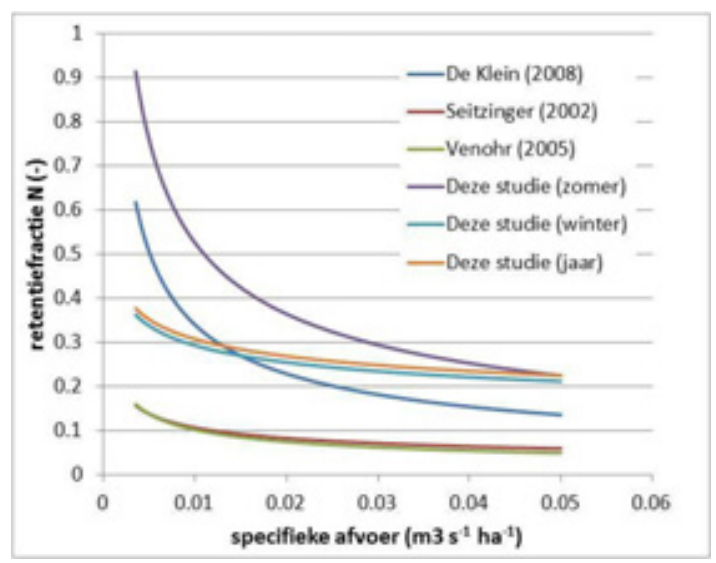

Figuur B4.2 Verband tussen de retentiefractie voor stikstof en de 'specifieke afvoer', gevonden in verschillende studies naar laaglandstroomgebieden in Europa en Amerika. NB De ruimtelijke en temporele schaal waarop de verbanden zijn afgeleid, verschillen sterk per studie: van grote stroomgebieden (860-14.000 km²) op jaarbasis (Venohr, 2005) naar kleinere stroomgebieden (20-400 $\mathrm{km}^{2}$ ) op jaarbasis (Seitzinger, 2002), winter- en zomerhalfjaar (deze studie) en maandbasis (Klein, 2011). Daarbij heeft de in deze studie berekende retentiefractie alleen betrekking op de nutriëntenuitspoeling vanuit het landsysteem, in tegenstelling tot de andere studies die de overige nutriëntenbronnen ook meenemen. 


\section{Referenties}

Boekel, E.M.P.M. van, L.P.A. van Gerven, T. van Hattum, V.G.M. Linderhof, H.T.L. Massop, H.M. Mulder, N.B.P. Polman, L.V. Renaud en D.J.J. Walvoort, 2011. Ex-ante evaluatie landbouw en KRW. Alterra rapport 2121, Alterra, Wageningen.

Gerven, L.P.A. van, A.A.M.F.R. Smit, P. Groenendijk, F.J.E. van der Bolt en J.J.M. de Klein, 2009. Retentieschatting van $\mathrm{N}$ en $\mathrm{P}$ in het oppervlaktewater op verschillende schaalniveau's. Alterra rapport 1848, Alterra, Wageningen.

Klein, J. M. de, A. Koelmans, 2011. Quantifying seasonal export and retention of nutriënts in West European lowland rivers at catchment scale. Hydrological Processes 25 (13), 2102-2111.

Massop H.Th.L, J.W.J. van der Gaast \& A.G.M. Hermans; Kenmerken van het ontwateringsstelsel in Nederland. Alterra rapport 1397, gepubliceerd: 28 feb 2007; 94 pp.

Muhammetoglu, A. and S. Soyupak, 2000. A three-dimensional water quality-macrophyte interaction model for shallow lakes. Ecological Modelling, Vol. 133, pp. 161-180.

Roelsma, J., B. van der Grift, H.M. Mulder en T.P. van Tol-Leenders, 2011a. Nutriëntenhuishouding in de bodem en het oppervlaktewater van de Drentsche Aa. Bronnen, routes en sturingsmogelijkheden. Reeks Monitoring Stroomgebieden 25-I. Alterra rapport 2218.

Roelsma, J., B. van der Grift, H.M. Mulder en T.P. van Tol-Leenders, 2011b. Nutriëntenhuishouding in de bodem en het oppervlaktewater van de Schuitenbeek. Bronnen, routes en sturingsmogelijkheden. Reeks Monitoring Stroomgebieden 25-II. Wageningen, Alterra, rapportnummer 2219.

Roijackers, R., Szabó, S., and Scheffer, M., 2004. Experimental analysis of the competition between algae and duckweed. Hydrobiologie 160, 401-412.

Seitzinger S.P., Styles R.V., Boyer E.W., Alexander R.B., Billen G., Howarth, R.W., Mayer B., Van Breemen N. 2002. Nitrogen retention in rivers: model development and application to watersheds in the northeastern USA. Biogeochemistry 57: 199-237.

Siderius C., P. Groenendijk, L.P.A. van Gerven, M.H.J.L. Jeuken, A.A.M.F.R Smit, 2008. Process description of NuswaLite; a simplified model for the fate of nutriënts in surface waters. Alterra Report 1226.2, Alterra, Wageningen.

Siderius, C., J. Roelsma, H.M. Mulder, L.P.A. van Gerven, R.F.A. Hendriks en T.P. van Tol-Leenders, 2011. Kalibratie Modelsysteem Monitoring Stroomgebieden. Reeks Monitoring Stroomgebieden 22. Alterra rapport 2216, Alterra, Wageningen.

Smit A.A.M.F.R, C. Siderius, L.P.A. van Gerven, 2009. Process description of SWQN; A simplified hydraulic model. Alterra Report 1226.1, Alterra, Wageningen.

Venohr M., Donohue I., Fogelberg S., Arheimer B., Irvine K. \& Behrendt H. (2005) Nitrogen retention in a river system and the effects of river morphology and lakes. Water Science and Technology, $51,19-29$.

Veraart, A.J., W. J. J. de Bruijne, J. M. de Klein, T. H. M. Peeters, M. Scheffer, 2011a. Effects of aquatic vegetation type on denitrification. Biogeochemistry 104:267-274.

Veraart, A.J., de Klein, J.J.M., Scheffer, M., 2011b. Warming Can Boost Denitrification Disproportionately Due to Altered Oxygen Dynamics. PLoS ONE 6(3): e18508. doi:10.1371/journal.pone.0018508

Veraart, A.J., M. Rocha Dimitrov, A. Schrier-Uijl, F. Gillissen, H. Smidt, J.J.M. de Klein, Denitrification in Dutch drainage ditches, relations with nitrate and nirK abundance. (tentative title)

Wolf, J., A.H.W. Beusen, P. Groenendijk, T. Kroon, R. Rötter en H. van Zeijts, 2003. The integrated modelling system STONE for calculating nutriënt emissions from agriculture in the Netherlands, Environ. Modelling \& Software, 18, pp. 397-417. 


\section{Bijlage 5 Resultaten herschikking}

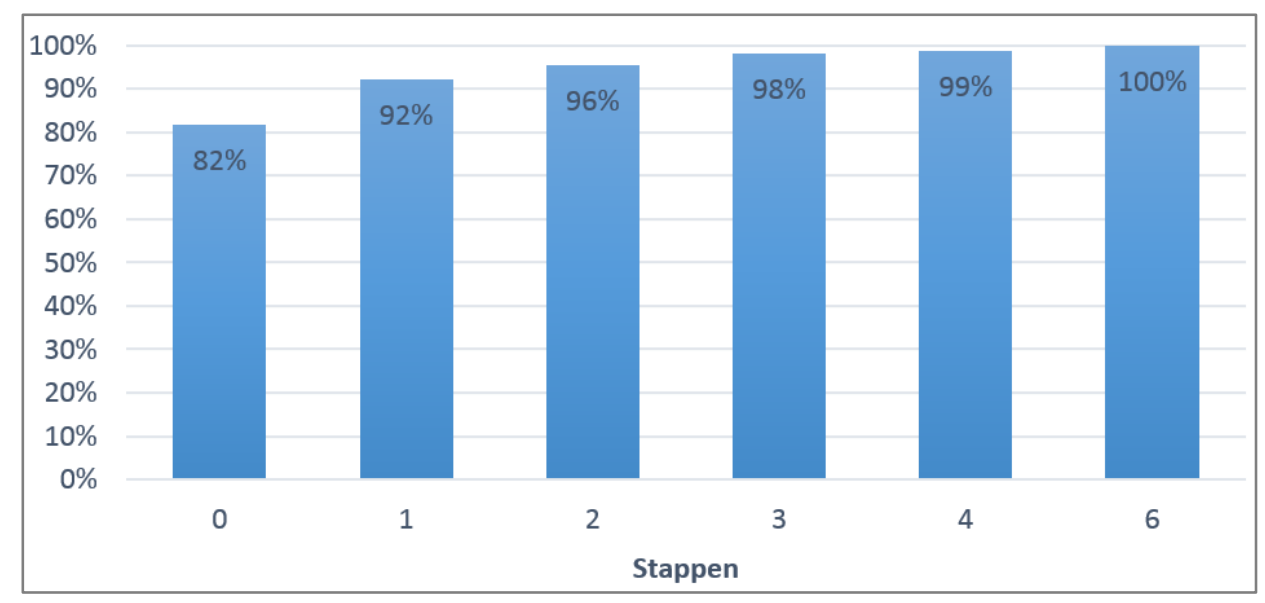

Figuur B5.1 Dekkingsgraad (als \% areaal van het gehele studiegebied) van de zoektocht naar SWAPANIMO-rekenplots met de juiste kenmerken, na het doorlopen van de verschillende stappen van de herschikkingsprocedure. Te zien is dat $82 \%$ van het studiegebied al gelijk kon worden toegekend aan een SWAP-ANIMO-rekenplot (stap 0, 1:1 match). Voor de resterende 18\% van het studiegebied werd na het doorlopen van de herschikkingsprocedure ook een geschikte SWAP-ANIMO-plot gevonden. Hiervoor waren de volgende stappen nodig (zie tabel B1.7): stap 1= Trapsgewijze aanpassing van bodemtypes met restricties, stap 2 = Trapsgewijze aanpassing van de Gt-klasse met restricties o.b.v. GHG (focus oppervlaktewater), stap 3 = Combinatie van stap 1 en 2, stap 4 = Aanpassing bodemfysische gegeven met beperkte restricties, stap $6=$ Geen restricties t.a.v. de Gt-klasse.

Tabel B5.1 Kenmerken van het landelijk gebied in de onderzochte polders, zoals blijkt uit de kenmerken van de rekenplots na de herschikkingsprocedure.

\begin{tabular}{|c|c|c|c|c|c|c|c|c|c|c|}
\hline \multirow[t]{2}{*}{ polder } & \multicolumn{4}{|c|}{ landgebruik (\%) } & \multicolumn{2}{|c|}{ bodem $(\%)$} & \multicolumn{3}{|c|}{ GT-klasse ( $\%)$} & \multirow{2}{*}{$\begin{array}{c}\text { hydrologie } \\
\text { kwel (mm/jaar) }\end{array}$} \\
\hline & akkerbouw & gras & mais & natuur & klei & veen & droog & midden & nat & \\
\hline Binnenwegse & 29 & 57 & 2 & 13 & 100 & 0 & 0 & 65 & 35 & 98 \\
\hline Eendragts & 57 & 33 & 4 & 5 & 87 & 13 & 2 & 10 & 88 & 172 \\
\hline EGB & 0 & 78 & 1 & 21 & 41 & 59 & 0 & 0 & 100 & -100 \\
\hline Tweemans & 86 & 12 & 0 & 3 & 100 & 0 & 0 & 73 & 27 & 111 \\
\hline Wilde Veenen & 87 & 11 & 1 & 1 & 100 & 0 & 0 & 54 & 46 & 133 \\
\hline Zuidplas-Noord & 40 & 56 & 2 & 2 & 83 & 17 & 1 & 33 & 67 & 163 \\
\hline Zuidplas-Zuid & 18 & 76 & 5 & 1 & 41 & 59 & 1 & 17 & 82 & 124 \\
\hline
\end{tabular}




\section{Bijlage 6 Af- en uitspoeling per jaar}

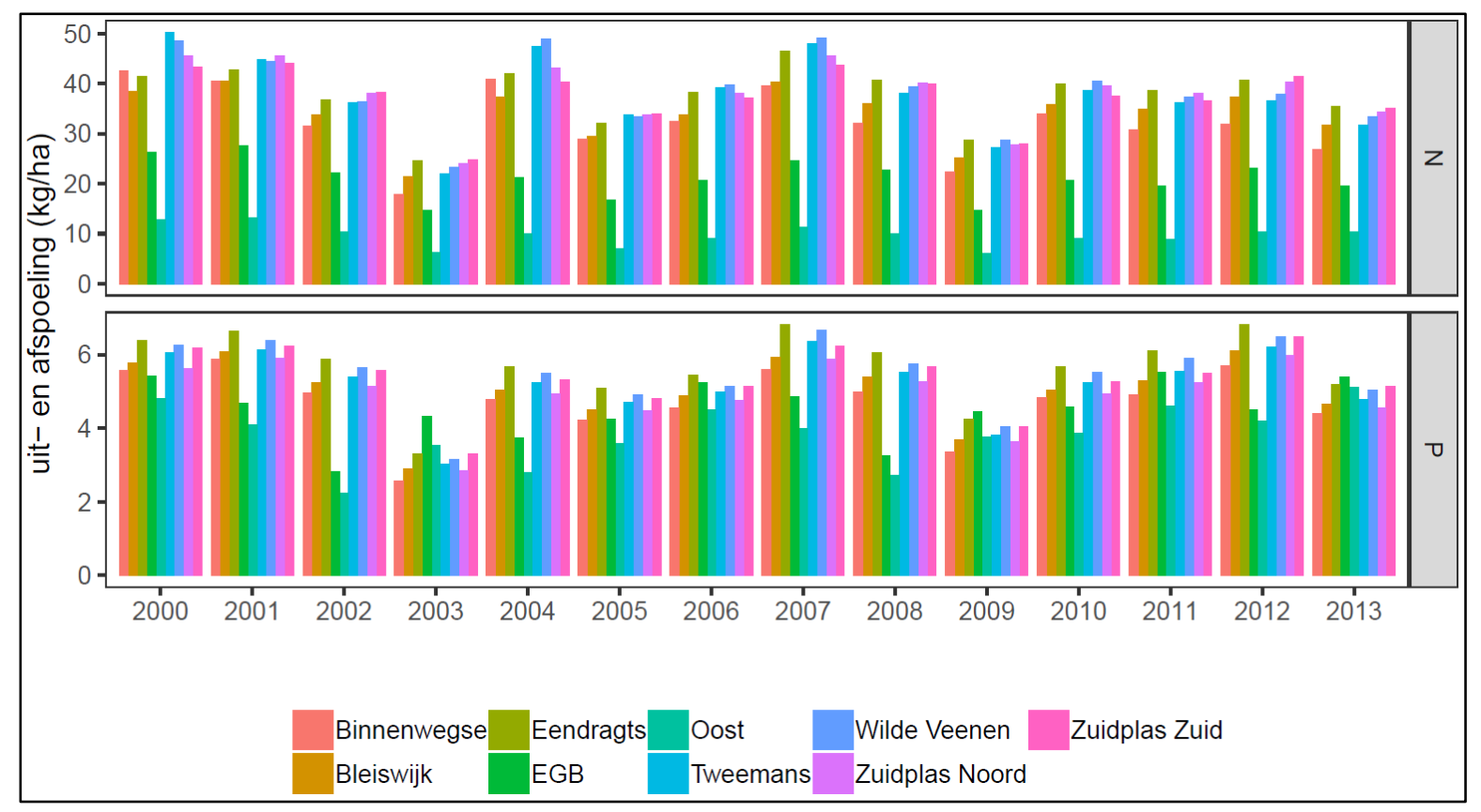

Figuur B6.1 Af- en uitspoeling per polder en per jaar, voor $N$ (boven) en $P$ (beneden), uitgedrukt in $\mathrm{kg}$ per hectare landelijk gebied; het gebied waarvoor de af- en uitspoeling is berekend (dus zonder glastuinbouw, stedelijk verhard en open water) 


\section{Bijlage 7 Nutriëntenbelasting per jaar}

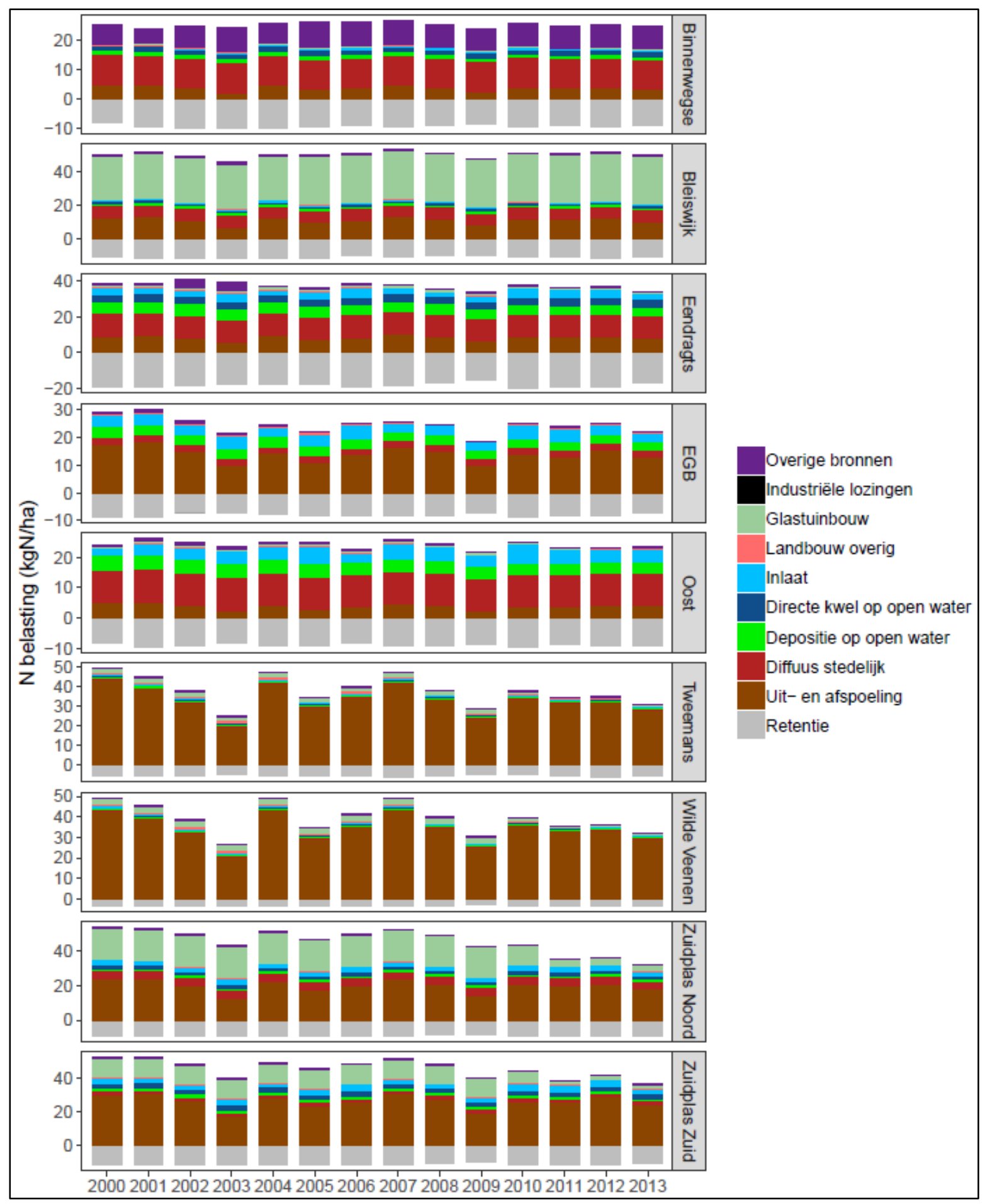

Figuur B7.1 Totale stikstofbelasting per polder en per jaar, uitgesplitst in de verschillende bronnen. Tevens is de berekende stikstofretentie weergegeven (als negatieve bron). 


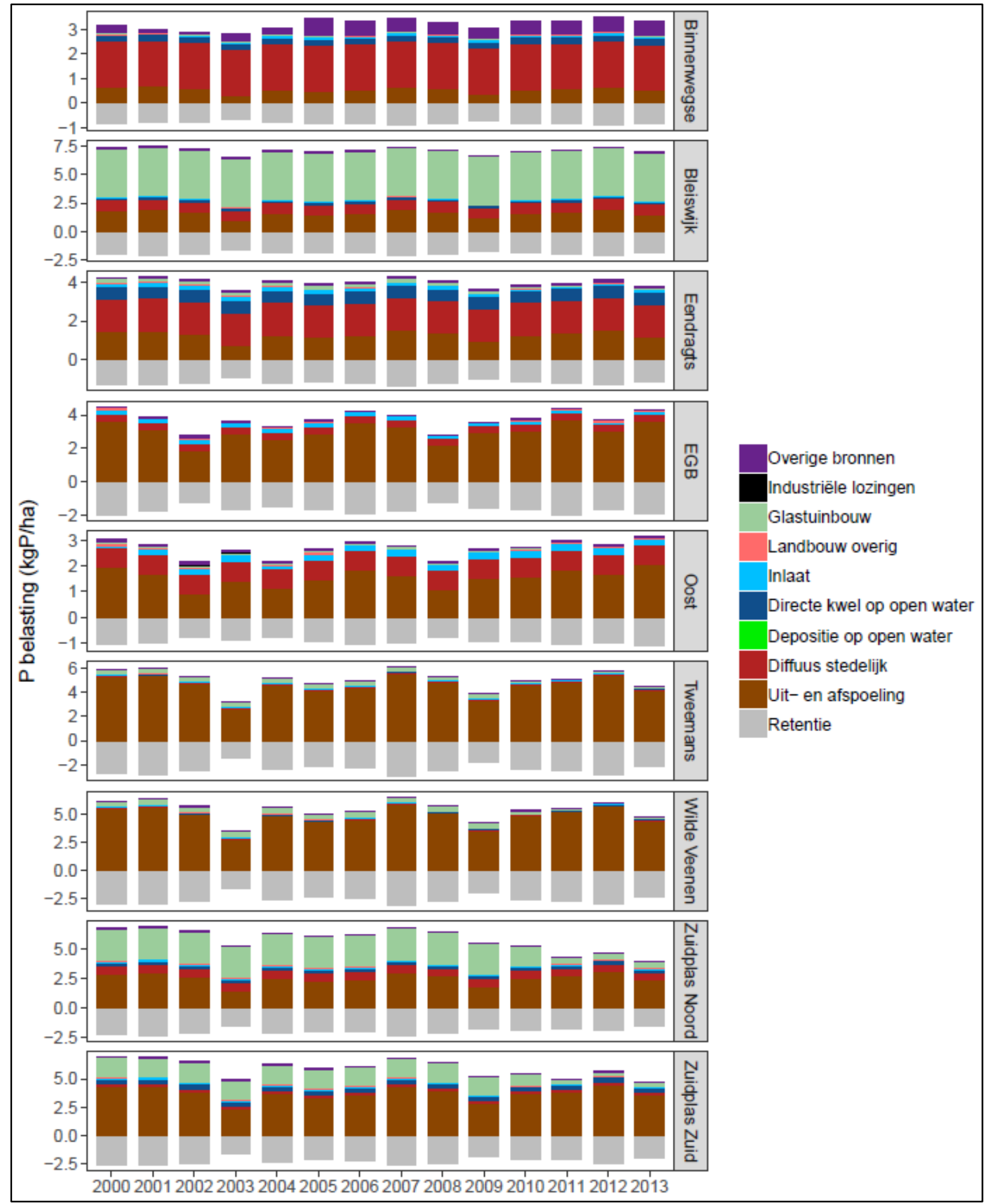

Figuur B7.2 Totale fosforbelasting per polder en per jaar, uitgesplitst in de verschillende bronnen. Tevens is de berekende fosforretentie weergegeven (als negatieve bron). 
Wageningen Environmental Research Postbus 47

6700 AA Wageningen

T 0317480700

www.wur.nl/environmental-research

Wageningen Environmental Research Rapport 2969

ISSN 1566-7197
De missie van Wageningen University \& Research is 'To explore the potential of nature to improve the quality of life'. Binnen Wageningen University \& Research bundelen Wageningen University en gespecialiseerde onderzoeksinstituten van Stichting Wageningen Research hun krachten om bij te dragen aan de oplossing van belangrijke vragen in het domein van gezonde voeding en leefomgeving. Met ongeveer 30 vestigingen, 5.000 medewerkers en 10.000 studenten behoort Wageningen University \& Research wereldwijd tot de aansprekende kennisinstellingen binnen haar domein. De integrale benadering van de vraagstukken en de samenwerking tussen verschillende disciplines vormen het hart van de unieke Wageningen aanpak. 



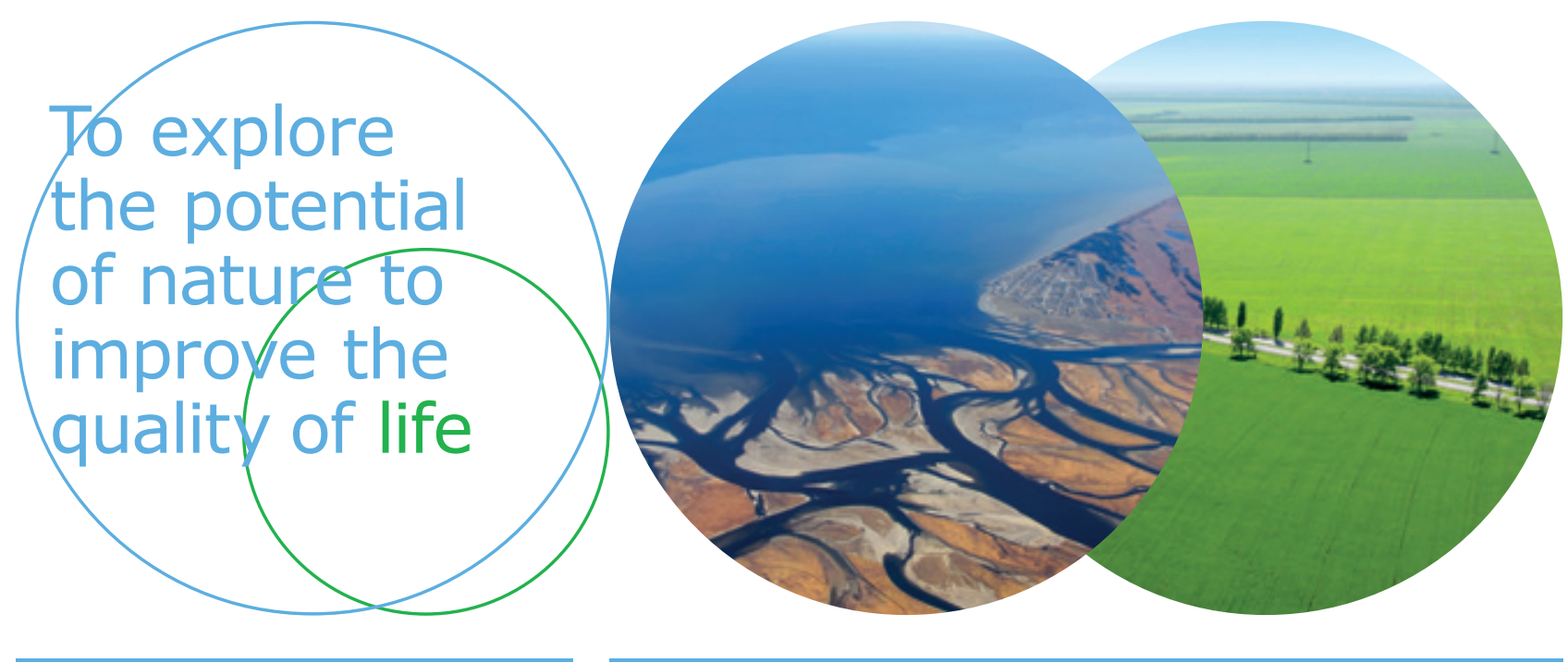

Wageningen Environmental Research Postbus 47

$6700 \mathrm{AB}$ Wageningen

T 317480700

www.wur.nl/environmental-research

Rapport 2969

ISSN 1566-7197
De missie van Wageningen University \& Research is 'To explore the potential of nature to improve the quality of life'. Binnen Wageningen University \& Research bundelen Wageningen University en gespecialiseerde onderzoeksinstituten van Stichting Wageningen Research hun krachten om bij te dragen aan de oplossing van belangrijke vragen in het domein van gezonde voeding en leefomgeving. Met ongeveer 30 vestigingen, 5.000 medewerkers en 10.000 studenten behoort Wageningen University \& Research wereldwijd tot de aansprekende kennisinstellingen binnen haar domein. De integrale benadering van de vraagstukken en de samenwerking tussen verschillende disciplines vormen het hart van de unieke Wageningen aanpak. 